$B$ gl 


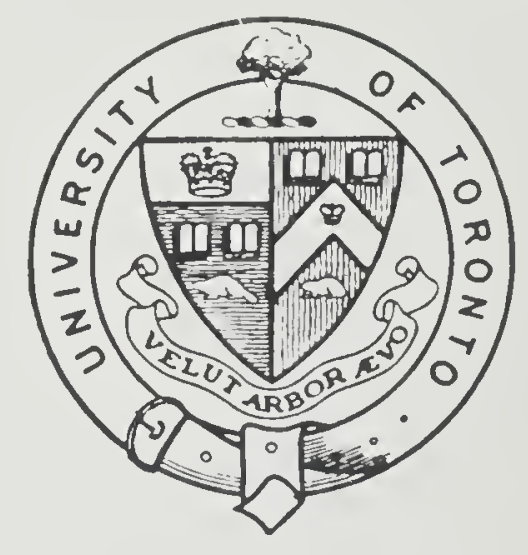

\section{Presented to the}

UNIVERSITY OF TORONTO

LIBRARY

by the

ONTARIO LEGISLATIVE LIBRARY

1980 

$695-$ 


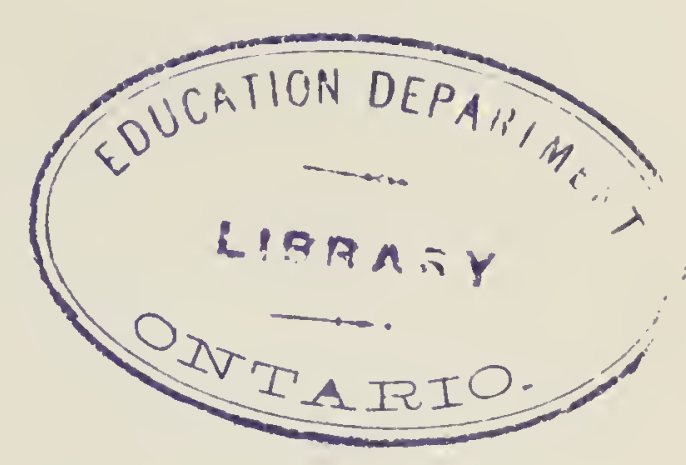


Digitized by the Internet Archive in 2020 with funding from University of Toronto 



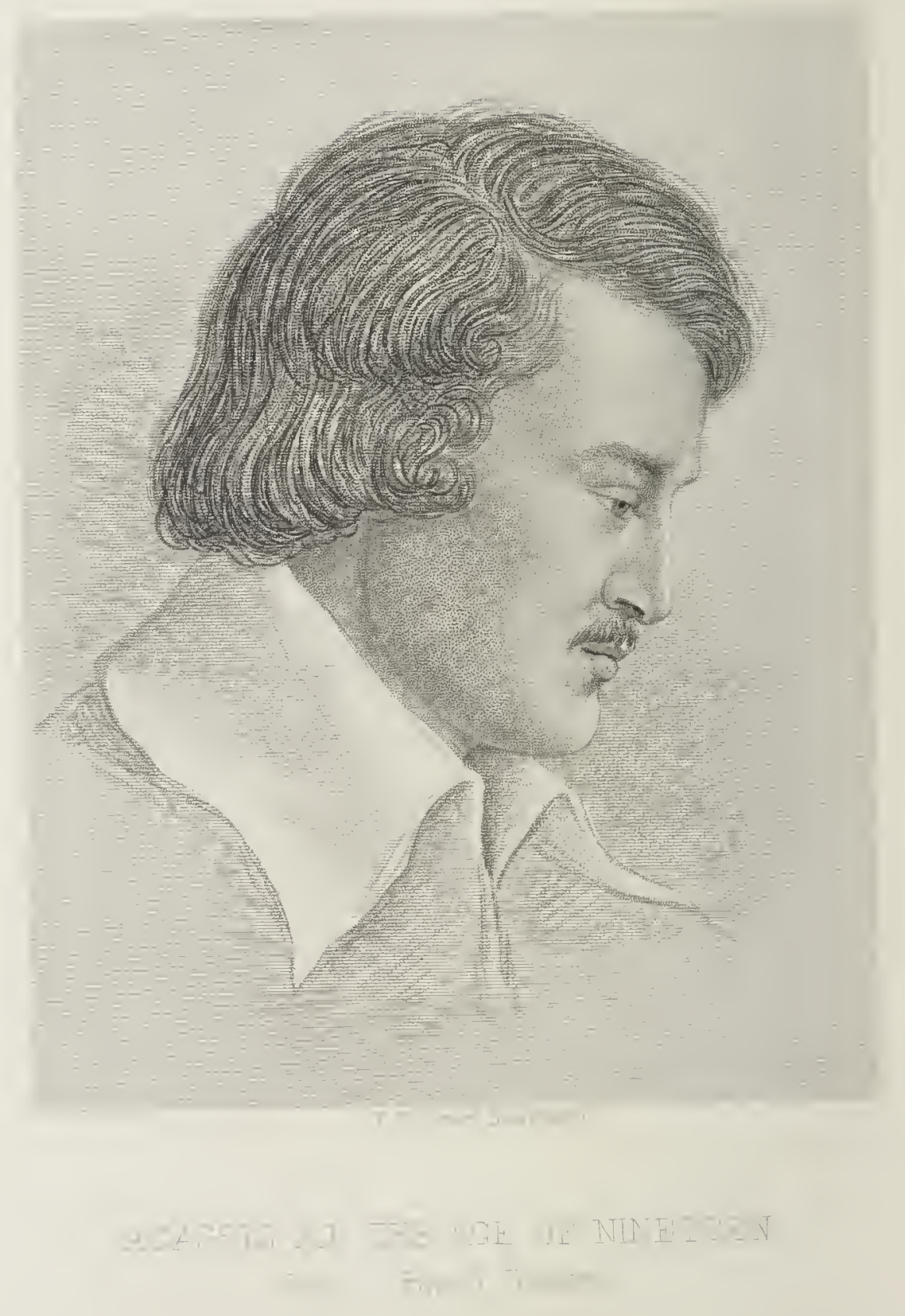




\title{
LOUIS AGASSIZ
}

\section{HIS LIFE AND CORRESPONDENCE}

\author{
EDITED BY
}

ELIZABETH CARY AGASSIZ

IN TWO VOLUMES

VOL. I.
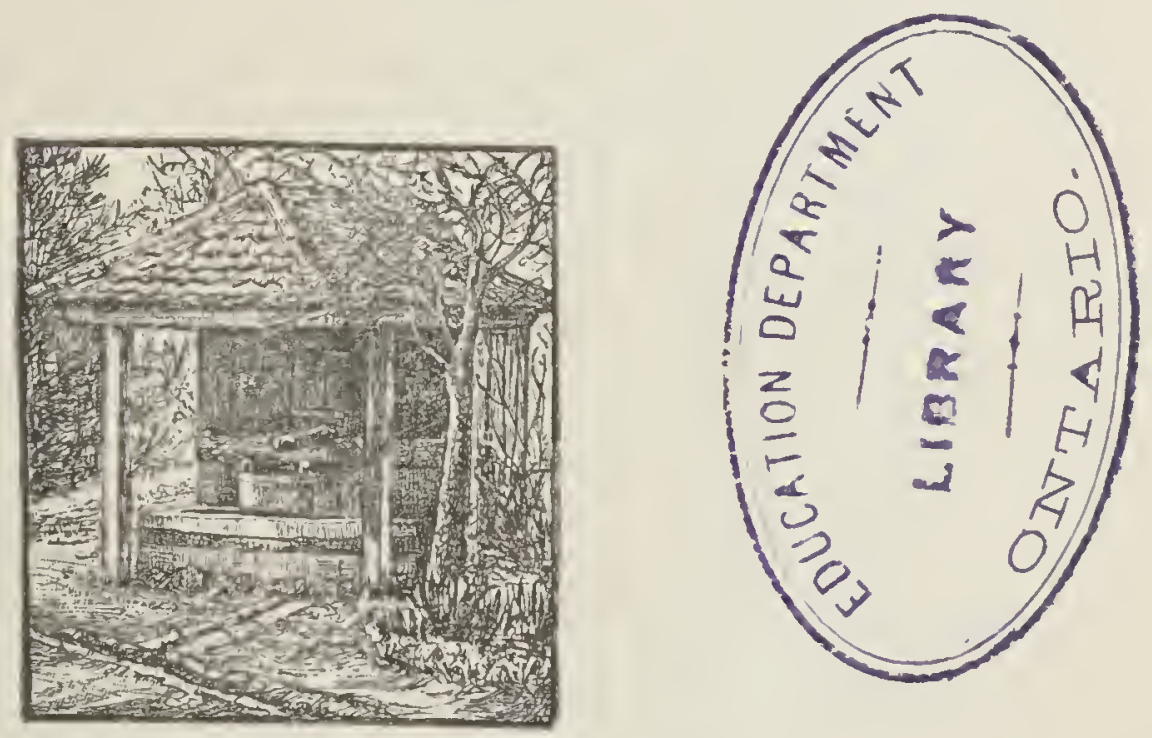

BOSTON

HOUGHTON, MIFFLIN AND COMPANY

New York: 11 East Seventeenth Street

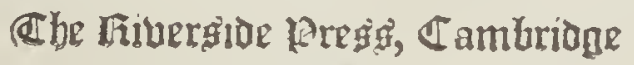




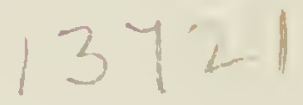

Copyright: 1885,

BI ELIZABETH CARY AGASSIZ.

All rights reserved.

SEVENTH EDITION.

The Riverside Press, Cambridge:

Flectrotyped and Printed by H. O. Houghton \& Co. 


\section{PREFACE.}

I AM aware that this book has neither the fullness of personal narrative, nor the closeness of scientific analysis, which its too comprehensive title might lead the reader to expect. A word of explanation is therefore needed. I thought little at first of the general public, when I began to weave together in narrative form the facts, letters, and journals contained in these volumes. My chief object was to prevent the dispersion and final loss of scattered papers which had an unquestionable family value. But, as my work grew upon my hands, I began to feel that the story of an in= tellectual life, which was marked by such rare coherence and unity of aim, might have a wider interest and usefulness; might, perhaps, 
serve as a stimulus and an encouragement to others. For this reason, and also because I am inclined to believe that the European portion of the life of Louis Agassiz is little known in his adopted country, while its American period must be unfamiliar to many in his native land, I have determined to publish the material here collected.

The book labors under the disadvantage of being in great part a translation. The correspondence for the first volume was almost wholly in French and German, so that the choice lay between a patch-work of several languages or the unity of one, burdened as it must be with the change of version. I have accepted what seemea to me the least of these difficulties.

Besides the assistance of my immediate family, including the revision of the text by my son Alexander Agassiz, I have been indebted to my friends Dr. and Mrs. Hagen and to the late Professor Guyot for advice on special points. 
As will be seen from the list of illustrations, I have also to thank Mrs. John W. Elliot for her valuable aid in that part of the work.

On the other side of the water I have had most faithful and efficient collaborators. Mr. Auguste Agassiz, who survived his brother Louis several years, and took the greatest interest in preserving whatever concerned his scientific career, confided to my hands many papers and documents belonging to his brother's earlier life. After his death, his cousin and brother-in-law, Mr. Auguste Mayor, of Neuchâtel, continued the same affectionate service. Without their aid I could not have completed the narrative as it now stands.

The friend last named also selected from the glacier of the Aar, at the request of Alexander Agassiz, the boulder which now marks his father's grave. With unwearied patience Mr. Mayor passed hours of toilsome search among the blocks of the moraine near the site of the old "Hôtel des Neuchâtelois," and 
vi PREFACE.

chose at last a stone so monumental in form that not a touch of the hammer was needed to fit it for its purpose. In conclusion I allow myself the pleasure of recording here my gratitude to him and to all who have aided me in my work.

ELIZABETH C. AGASSIZ.

Cambridge, Mass., June 11, 1885. 


\section{CONTENTS OF VOL. I.}

\section{CHAPTER $\mathrm{T}$.}

1807-1827 : TO ÆT. 20.

Birthplace. - Influence of his Mother. - Early Love of Natural History. - Boyish Occupations. - Domestic Education. - First School. - Vacations. Commercial Life renounced. - College of Lausanne. - Choice of Profession. - Medical School of Zurich. - Life and Studies there. - University of Heidelberg. - Studies interrupted by Illness. - Return to Switzerland. - Occupations during Convalescence .

\section{CHAPTER II.}

1827-1828: ET. 20-21.

Arrival in Munich. - Lectures. - Relations with the Professors. - Schelling, Martius, Oken, Döllinger. - Relations with Fellow-Students. - The Little Academy. - Plans for Traveling. - Advice from his Parents. - Vacation Journey. - Tri-Centennial Dürer Festival at Nuremberg . . . .

CHAPTER III.

1828-1829 : ÆT. 21-22.

First Important Work in Natural History. - Spix's Brazilian Fishes. - Second Vacation Trip. - Sketch 
of Work during University Year. - Extracts from the Journal of Mr. Dinkel. - Home Letters. - Hope of joining Humboldt's Asiatic Expedition. - Diploma of Philosophy. - Completion of First Part of the Spix Fishes. - Letter concerning it from Cuvier .

CHAPTER IV.

$$
1829-1830 \text { : ÆT. } 22-23 .
$$

Scientific Meeting at Heidelberg. - Visit at Home. Illness and Death of his Grandfather. - Return to Munich. - Plans for Future Scientific Publications. - Takes his Degree of Medicine. - Visit to Vienna. - Return to Munich. - Home Letters. - Last Days at Munich. - Autobiographical Review of School and University Life . . . . . . .

CHAPTER V.

$1830-1832$ : ÆT. $23-25$.

Year at Home. - Leaves Home for Paris. - Delays on the Road. - Cholera. - Arrival in Paris. - First Visit to Cuvier. - Cuvier's Kinduess. - His Death. - Poverty in Paris. - Home Letters concerning Embarrassments and about his Work. - Singular Dream . . . . . . . . .

\section{CHAPTER VI.}

\section{2 : «T. 25.}

Unexpected Relief from Difficulties. - Correspondence with Humboldt. - Excursion to the Coast of Normandy. - First Sight of the Sea. - Correspondence concerning Professorship at Neuchâtel. - Birthday Fête. - Invitation to Chair of Natural History at Neuchâtel. - Acceptance. - Letter to Humboldt . 


\section{CHAPTER VII.}

$1832-1834$ : שT. 25-27.

Enters upon his Professorship at Neuchâtel. - First Lecture. - Success as a Teacher. - Love of Teaching. - Influence upon the Scientific Life of Neuchâtel. - Proposal from University of Heidelberg. Proposal declined. - Threatened Blindness. - Correspondence with Humboldt. - Marriage. - Invitation from Charpentier. - Invitation to visit England. - Wollaston Prize. - First Number of "Poissons Fossiles." - Review of the Work . . . .

\section{CHAPTER VIII.}

$$
1834-1837 \text { : ÆT. } 27-30 \text {. }
$$

First Visit to England. - Reception by Scientific Men. - Work on Fossil Fishes there. - Liberality o? English Naturalists. - First Relations with American Science. - Farther Correspondence with Humboldt. - Second Visit to England. - Continuation of "Fossil Fishes." - Other Scientific Publications. - Attention drawn to Glacial Phenomena. - Summer a’: Bex with Charpentier. - Sale of Original Drawings for "Fossil Fishes." - Meeting of Helvetic Society. Address on Ice-Period. - Letters from Humboldt and Von Buch.

\section{CHAPTER IX.}

$$
1837-1839 \text { : ÆT. } 30-32 \text {. }
$$

Invitation to Professorships at Geneva and Lausanne. - Death of his Father. - Establishment of Iithographic Press at Neuchâtel. - Researches upon Structure of Mollusks. - Internal Casts of Shells. Glacial Explorations. - Views of Buckland. - Rele. 
tions with Arnold Guyot. - Their Work together in the Alps. - Letter to Sir Philip Egerton concerning Glacial Work. - Summer of 1839. - Publication of "Etudes sur les Glaciers" . . . . .

\section{CHAPTER X.}

1840-1842 : «T. 33-35.

Summer Station on the Glacier of the Aar. - Hôtel des Neuchâtelois. - Members of the Party. - Work on the Glacier. - Ascent of the Strahleck and the Siedelhorn. - Visit to England. - Search for Glacial Remains in Great Britain. - Roads of Glen Roy.Views of English Naturalists concerning Agassiz's Glacial Theory. - Letter from Humboldt. - Winter Visit to Glacier. - Summer of 1841 on the Glacier. - Descent into the Glacier. - Ascent of the Jungfrau

\section{CHAPTER XI.}

$$
\text { 1842-1843 : ET. 35-36. }
$$

Zoölogical Work uninterrupted by Glacial Researches. - Various Publications. - "Nomenclator Zoölogicus." - "Bibliographia Zoölogiæ et Geologiæ." Correspondence with English Naturalists. - Correspondence with Humboldt. - Glacial Campaign of 1842. - Correspondence with Prince de Canino concerning Journey to United States. - Fossil Fishes from the Old Red Sandstone. - Glacial Campaign of 1843. - Death of Leuthold, the Guide . . .

\section{CHAPTER XII.}

1843-1846 : жT. 36-39.

Completion of Fossil Fishes. - Followed by Fossil Fishes of the Old Red Sandstone. - Review of the Later Work. - Identification of Fishes by the Skull. 
- Renewed Correspondence with Prince Canino about Journey to the United States. - Change of Plan owing to the Interest of the King of Prussia in the Expedition. - Correspondence between Professor Sedgwick and Agassiz on Devolopment Theory. - Final Scientific Work in Neuchâtel and Paris. Publication of "Système Glaciaire." - Short Stay in England. - Farewell Letter from Humboldt. - Sails for United States . • • • • • • 366 



\section{IIST OF ILLUSTRATIONS. VOLUME I.}

I. Portrait of Louis Agassiz at the Age of Nineteen ; copied by Mrs. John W. Elliot from a pastel-drawing by Cecile Braun Frontispiece

II. The Stone Basin at Motier; drawn by Mrs. Elliot from a photograph . . . Vignette

III. The Birthplace of Louis Agassiz; from a

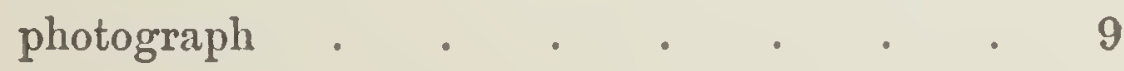

IV. Hôtel des Neuchâtelois ; copied by Mrs. Elliot from an oil sketch made on the spot by J. Burkhardt . . . . . . . 305

V. Portrait of Jacob Leuthold; from a portrait by J. Burkhardt . . . . . 329

VI. Second Station on the Aar Glacier; copied by Mrs. Elliot from a sketch in oil by J. Burkhardt . . . . . . . 



\section{LOUIS AGASSIZ:}

\section{HIS LIFE AND CORRESPONDENCE.}

\section{CHAPTER I. \\ $1807-1827$ : TO ET. 20.}

Birthplace. - Influence of his Mother. - Early Love of Nat. ural History. - Boyish Occupations. - Domestic Education. - First School. - Vacations. - Commercial Life renounced. - College of Lausanne. - Choice of Profession. - Medical School of Zurich. - Life and Studies there. University of Heidelberg. - Studies interrupted by Illness. - Return to Switzerland. - Occupations during Convalescence.

Jean Louis Rodolphe Agassiz was born May 28, 1807, at the village of Motier, on the Lake of Morat. His father, Louis Rodolphe Agassiz, was a clergyman; his mother, Rose Mayor, was the daughter of a physician whose home was at Cudrefin, on the shore of the Lake of Neuchâtel.

The parsonages in Switzerland are frequently pretty and picturesque. That of Motier, looking upon the lake and sheltered by a hill which commands a view over the whole VOL. I. 
chain of the Bernese Alps, was especially so. It possessed a vineyard large enough to add something in good years to the small salary of the pastor; an orchard containing, among other trees, an apricot famed the country around for the unblemished beauty of its abundant fruit; a good vegetable garden, and a delicious spring of water flowing always fresh and pure into a great stone basin behind the house. That stone basin was Agassiz's first aquarium; there he had his first collection of fishes. ${ }^{1}$

It does not appear that he had any precocious predilection for study, and his parents, who for the first ten years of his life were his only teachers, were too wise to stimulate his mind beyond the ordinary attainments of his age. Having lost her first four children in infancy, his mother watched with trembling solicitude over his early years. It was perhaps for this reason that she was drawn so closely to her boy, and understood that his love of nature, and especially of all living

1 After his death a touching tribute was paid to his memory by the inhabitants of his birthplace. With appropriate ceremonies, a marble slab was placed above the door of the parsonage of Motier, with this inscription, "J. Louis Agassiz, célèbre naturaliste, est né dans cette maison, le $28 \mathrm{Mai}$, 1807." 
things, was an intellectual tendency, and not simply a child's disposition to find friends and playmates in the animals about him. In later years her sympathy gave her the key to the work of his manhood, as it had done to the sports of his childhood. She remained his most intimate friend to the last hour of her life, and he survived her but six years.

Louis's love of natural history showed itself almost from infancy. When a very little fellow he had, beside his collection of fishes, all sorts of pets : birds, field-mice, hares, rabbits, guinea-pigs, etc., whose families he reared with the greatest care. Guided by his knowledge of the haunts and habits of fishes, he and his brother Auguste became the most adroit of young fishermen, - using processes all their own and quite independent of hook, line, or net. Their hunting grounds were the holes and crevices beneath the stones or in the

- water-washed walls of the lake shore. No such shelter was safe from their curious fingers, and they acquired such dexterity that when bathing they could seize the fish even in the open water, attracting them by little arts to which the fish submitted as to a kind of fascination. Such amusements are no doubt the delight of many a lad living in the coun- 
try, nor would they be worth recording except as illustrating the unity of Agassiz's intellectual development from beginning to end. His pet animals suggested questions, to answer which was the task of his life; and his intimate study of the fresh-water fishes of Europe, later the subject of one of his important works, began with his first collection from the Lake of Morat.

As a boy he amused himself also with all kinds of handicrafts on a small scale. The carpenter, the cobbler, the tailor, were then as much developed in him as the naturalist. In Swiss villages it was the habit in those days for the trades-people to go from house to house in their different vocations. The shoemaker came two or three times a year with all his materials, and made shoes for the whole family by the day; the tailor came to fit them for garments which he made in the house; the cooper arrived before the vintage, to repair old barrels and hogsheads or to make new ones, and to replace their worn-out hoops; in short, to fit up the cellar for the coming season. Agassiz seems to have profited by these lessons as much as by those he learned from his father; and when a very little fellow, he could cut and put together a well-fitting pair of shoes 
for his sisters' dolls, was no bad tailor, and could make a miniature barrel that was perfectly water-tight. He remembered these trivial facts as a valuable part of his incidental education. He said he owed much of his dexterity in manipulation, to the training of eye and hand gained in these childish plays.

Though fond of quiet, in-door occupation, he was an active, daring boy. One winter day when about seven years of age, he was skating with his little brother Auguste, two years younger than himself, and a number of other boys, near the shore of the lake. They were talking of a great fair held that day at the town of Morat, on the opposite side of the lake, to which M. Agassiz had gone in the morning, not crossing upon the ice, however, but driving around the shore. The temptation was too strong for Louis, and he proposed to Auguste that they should skate across, join their father at the fair, and come home with him in the afternoon. They started accordingly. The other boys remained on their skating ground till twelve o'clock, the usual dinner hour, when they returned to the village. Mme. Agassiz was watching for her boys, thinking them rather late, and on in- 
quiring for them among the troop of urchins coming down the village street she learned on what errand they had gone. Her anxiety may be imagined. The lake was not less than two miles across, and she was by no means sure that the ice was safe. She hurried to an upper window with a spy-glass to see if she could descry them anywhere. At the moment she caught sight of them, already far on their journey, Louis had laid himself down across a fissure in the ice, thus making a bridge for his little brother, who was creeping over his back. Their mother directed a workman, an excellent skater, to follow them as swiftly as possible. He overtook them just as they had gained the shore, but it did not occur to him that they could return otherwise than they had come, and he skated back with them across the lake. Weary, hungry, and disappointed, the boys reached the house without having seen the fair or enjoyed the drive home with their father in the afternoon.

When he was ten years old, Agassiz was sent to the college for boys at Bienne, thus exchanging the easy rule of domestic instruction for the more serious studies of a public school. He found himself on a level with his class, however, for his father was an admirable 
teacher. Indeed it would seem that Agassiz's own passion for teaching, as well as his love of young people and his sympathy with intellectual aspiration everywhere, was an inheritance. Wherever his father was settled as pastor, at Motier, at Orbe, and later at Concise, his influence was felt in the schools as much as in the pulpit. A piece of silver remains, a much prized heir-loom in the family, given to him by the municipality of Orbe in acknowledgment of his services in the schools.

The rules of the school at Bienne were rather strict, but the life led by the boys was hardy and invigorating, and they played as heartily as they worked. Remembering his own school life, Agassiz often asked himself whether it was difference of climate or of method, which makes the public school life in the United States so much more trying to the health of children than the one under which he was brought up. The boys and girls in our public schools are said to be overworked with a session of five hours, and an additional hour or two of study at home. At the College of Bienne there were nine hours of study, and the boys were healthy and happy. Perhaps the secret might be found in the frequent interruption, two or three hours of 
study alternating with an interval for play or rest. Agassiz always retained a pleasant impression of the school and its teachers. Mr. Rickly, the director, he regarded with an affectionate respect, which ripened into friendship in maturer years.

The vacations were, of course, hailed with delight, and as Motier was but twenty miles distant from Bienne, Agassiz and his younger brother Auguste, who joined him at school a year later, were in the habit of making the journey on foot. The lives of these brothers were so closely interwoven in their youth that for many years the story of one includes the story of the other. They had everything in common, and with their little savings they used to buy books, chosen by Louis, the foundation, as it proved, of his future library.

Long before dawn on the first day of vacation the two bright, active boys would be on their homeward way, as happy as holiday could make them, especially if they were returning for the summer harvest or the autumn vintage. The latter was then, as now, a season of festivity. In these more modern days something of its primitive picturesqueness may have been lost; but when Agassiz was a boy, all the ordinary occupations were 



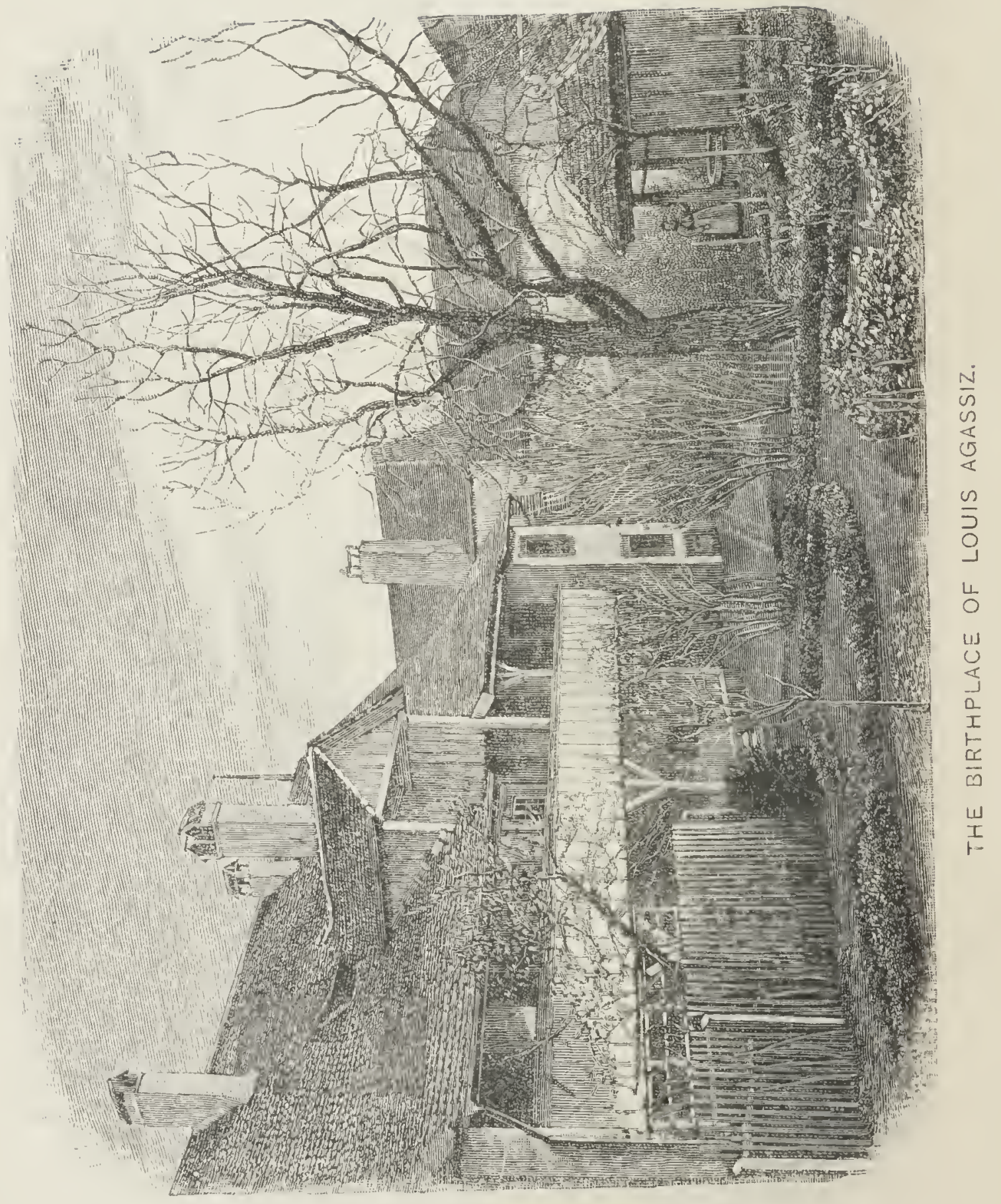


given up for this important annual business, in which work and play were so happily combined. On the appointed day the working people might be seen trooping in from neighboring cantons, where there were no vineyards, to offer themselves for the vintage. They either camped out at night, sleeping in the open air, or found shelter in the stables and outhouses. During the grape gathering the floor of the barn and shed at the parsonage of Motier was often covered in the evening with tired laborers, both men and women. Of course, when the weather was fine, these were festival days for the children. A bushel basket, heaped high with white and amber bunches, stood in the hall, or in the living room of the family, and young and old were free to help themselves as they came and went. Then there were the frolics in the vineyard, the sweet cup of must (unfermented juice of the grape), and the ball on the last evening at the close of the merry-making.

Sometimes the boys passed their vacations at Cudrefin, with their grandfather Mayor. He was a kind old man, much respected in his profession, and greatly beloved for his benevolence. His little white horse was well known in all the paths and by-roads of the 
country around, as he went from village to village among the sick. The grandmother was frail in health, but a great favorite among the children, for whom she had an endless fund of stories, songs, and hymns. Aunt Lisette, an unmarried daughter, who long lived to maintain the hospitality of the old Cudrefin house and to be beloved as the kindest of maiden aunts by two or three generations of nephews and nieces, was the domestic providence of these family gatherings, where the praises of her excellent dishes were annually sung. The roof was elastic; there was no question about numbers, for all came who could; the more, the merrier, with no diminution of good cheer.

The Sunday after Easter was the great popular fête. Then every house was busy coloring Easter eggs and making fritters. The young girls and the lads of the village, the former in their prettiest dresses and the latter with enormous bouquets of artificial flowers in their hats, went together to church in the morning. In the afternoon the traditional match between two runners, chosen from the village youths, took place. They were dressed in white, and adorned with bright ribbons. With music before them, and followed by all 
young people, they went in procession to the place where a quantity of Easter eggs had been distributed upon the ground. At a signal the runners separated, the one to pick up the eggs according to a prescribed course, the other to run to the next village and back again. The victory was to the one who accomplished his task first, and he was proclaimed king of the feast. Hand in hand the runners, followed as before by all their companions, returned to join in the dance now to take place before the house of Dr. Mayor. After a time the festivities were interrupted by a little address in patois from the first musician, who concluded by announcing from his platform a special dance in honor of the family of Dr. Mayor. In this dance the family with some of their friends and neighbors took part, - the young ladies dancing with the peasant lads and the young gentlemen with the girls of the village, - while the rest formed a circle to look on.

Thus, between study and recreation, the four years which Agassiz's father and mother intended he should pass at Bienne drew to a close. A yellow, time-worn sheet of foolscap, on which during the last year of his schoollife he wrote his desiderata in the way of 
books, tells something of his progress and his aspirations at fourteen years of age. "I wish," so it runs, "to advance in the sciences, and for that I need d'Anville, Ritter, an Italian dictionary, a Strabo in Greek, Mannert and Thiersch; and also the works of MalteBrun and Seyfert. I have resolved, as far as I am allowed to do so, to become a man of letters, and at present I can go no further: 1st, in ancient geography, for I already know all my note-books, and I have only such books as Mr. Rickly can lend me; I must have d'Anville or Mannert; 2d, in modern geography, also, I have only such books as Mr. Rickly can lend me, and the Osterwald geography, which does not accord with the new divisions; I must have Ritter or MalteBrun; 3d, for Greek I need a new grammar, and I shall choose Thiersch; 4th, I have no Italian dictionary, except one lent me by Mr. Moltz; I must have one; 5th, for Latin I need a larger grammar than the one I have, and I should like Seyfert; 6th, Mr. Rickly tells me that as I have a taste for geography he will give me a lesson in Greek (gratis), in which we would translate Strabo, provided I can find one. For all this I ought to have about twelve louis. I should like 
to stay at Bienne till the month of July, and afterward serve my apprenticeship in commerce at Neuchâtel for a year and a half. Then I should like to pass four years at $a$ university in Germany, and finally finish my studies at Paris, where I would stay about five years. Then, at the age of twenty-five, I could begin to write."

Agassiz's note-books, preserved by his parents, who followed the education of their children with the deepest interest, give evidence of his faithful work both at school and college. They form a great pile of manuscript, from the paper copy-books of the school-boy to the carefully collated reports of the college student, begun when the writer was ten or eleven years of age and continued with little interruption till he was eighteen or nineteen. The later volumes are of nearly quarto size and very thick, some of them containing from four to six hundred closely covered pages; the handwriting is small, no doubt for economy of space, but very clear. The subjects are physiological, pathological, and anatomical, with more or less of general natural history. This series of books is kept with remarkable neatness. Even in the boy's copy-books, containing exercises in Greek, Latin, French and 
German, with compositions on a variety of topics, the writing is even and distinct, with scarcely a blot or an erasure. From the very beginning there is a careful division of subjects under clearly marked headings, showing even then a tendency toward an orderly classification of facts and thoughts.

It is evident from the boyish sketch which he drew of his future plans that the hope of escaping the commercial life projected for him, and of dedicating himself to letters and learning, was already dawning. He had begun to feel the charm of study, and his scientific tastes, though still pursued rather as the pastimes of a boy than as the investigations of a student, were nevertheless becoming more and more absorbing. He was fifteen years old and the time had come when, according to a purpose long decided upon, he was to leave school and enter the business house of his uncle, François Mayor, at Neuchâtel. He begged for a farther delay, to be spent in two additional years of study at the College of Lausanne. He was supported in his request by several of his teachers, and especially by Mr. Rickly, who urged his parents to encourage the remarkable intelligence and zeal already shown by their son in his 
studies. They were not difficult to persuade; indeed, only want of means, never want of will, limited the educational advantages they gave to their children.

It was decided, therefore, that he should go to Lausanne. Here his love for everything bearing on the study of nature was confirmed. Professor Chavannes, Director of the Cantonal Museum, in whom he found not only an interesting teacher, but a friend who sympathized with his favorite tastes, possessed the only collection of Natural History in the Canton de Vaud. To this Agassiz now had access. His uncle, Dr. Mathias Mayor, his mother's brother and a physician of note in Lausanne, whose opinion had great weight with M. and Mme. Agassiz, was also attracted by the boy's intelligent interest in anatomy and kindred subjects. He advised that his nephew should be allowed to study medicine, and at the close of Agassiz's college course at Lausanne the commercial plan was finally abandoned, and he was permitted to choose the medical profession as the one most akin to his inclination.

Being now seventeen years of age, he went to the medical school of Zurich. Here, for the first time, he came into contact with men 
whose instruction derived freshness and vigor from their original researches. He was especially indebted to Professor Schinz, a man of learning and ability, who held the chair of Natural History and Physiology, and who showed the warmest interest in his pupil's progress. He gave Agassiz a key to his private library, as well as to his collection of birds. This liberality was invaluable to one whose poverty made books an unattainable luxury. Many an hour did the young student pass at that time in copying books which were beyond his means, though some of them did not cost more than a dollar a volume. His brother Auguste, still his constant companion, shared this task, a pure labor of love with him, for the books were more necessary to Louis's studies than to his own.

During the two years passed by Agassiz in Zurich he saw little of society beyond the walls of the university. His brother and he had a pleasant home in a private house, where they shared the family life of their host and hostess. In company with them, Agassiz made his first excursion of any importance into the Alps. They ascended the Righi and passed the night there. At about sunset a fearful thunder-storm gathered below them, 
while on the summit of the mountain the weather remained perfectly clear and calm. Under a blue sky they watched the lightning, and listened to the thunder in the dark clouds, which were pouring torrents of rain upon the plain and the Lake of Lucerne. The storm lasted long after night had closed in, and Agassiz lingered when all his companions had retired to rest, till at last the clouds drifted softly away, letting down the light of moon and stars on the lake and landscape. He used to say that in his subsequent Alpine excursions he had rarely witnessed a scene of greater beauty.

Such of his letters from Zurich as have been preserved have only a home interest. In one of them, however, he alludes to a curious circumstance, which might have changed the tenor of his life. $\mathrm{He}$ and his brother were returning on foot, for the vacation, from $\mathrm{Zu}$ rich to their home which was now in Orbe, where their father and mother had been settled since 1821. Between Neuchâtel and Orbe they were overtaken by a traveling carriage. A gentleman who was its sole occupant invited them to get in, made them welcome to his lunch, talked to them of their student life, and their future plans, and drove YOL. I. 
them to the parsonage, where he introduced himself to their parents. Some days afterward M. Agassiz received a letter from this chance acquaintance, who proved to be a man in affluent circumstances, of good social position, living at the time in Geneva. He wrote to M. Agassiz that he had been singularly attracted by his elder son, Louis, and that he wished to adopt him, assuming henceforth all the responsibility of his education and his establishment in life. This proposition fell like a bomb-shell into the quiet parsonage. M. Agassiz was poor, and every advantage for his children was gained with painful self-sacrifice on the part of both parents. How then refuse such an opportunity for one among them, and that one so gifted? After anxious reflection, however, the father, with the full concurrence of his son, decided to decline an offer which, brilliant as it seemed, involved a separation and might lead to a false position. A correspondence was kept up for years between Louis and the friend he had so suddenly won, and who continued to interest himself in his rareer. Although it had no sequel, this incident is mentioned as showing a kind of personal magnetism which, even as child and boy, Agassiz unconsciously exercised over others. 
From Zurich, Agassiz went to the University of Heidelberg, where we find him in the spring of 1826.

TO HIS FATHER.

Heidelberg, April 24, 1826.

...Having arrived early enough to see something of the environs before the opening of the term, I decided to devote each day to a ramble in one direction or another, in order to become familiar with my surroundings. I am the more glad to have done this as I have learned that after the lectures begin there will be no further chance for such interruptions, and we shall be obliged to stick closely to our work at home.

Our first excursion was to Neckarsteinach, two and a half leagues from here. The road follows the Neckar, and at certain places rises boldly above the river, which flows between two hills, broken by rocks of the color of red chalk, which often jut out from either side. Farther on the valley widens, and a pretty rising ground, crowned by ruins, suddenly presents itself in the midst of a wide plain, where sheep are feeding. Neckarsteinach it self is only a little village, containing, however, three castles, two of which are in ruins. 
The third is still inhabited, and commands a magnificent view. In the evening we returned to Heidelberg by moonlight.

Another day we started for what is here called "The Mountain," though it is at most no higher than Le Suchet. As the needful supplies are not to be obtained there, we took our provisions with us. We had so much fun out of this, that I must tell you all about it. In the morning $\mathrm{Z}$ - bouglit at the market veal, liver, and bacon enough to serve for three persons during two days. To these supplies we added salt, pepper, butter, onions, bread, and some jugs of beer. One of us took two saucepans for cooking, and some alcohol. Arrived at the summit of our mountain, we looked out for a convenient spot, and there we cooked our dinner. It did not take long, nor can I say whether all was done according to the rules of art. But this I know, - that never did a meal seem to me better. We wandered over the mountain for the rest of the day, and at evening came to a house where we prepared our supper after the same fashion, to the great astonishment of the assembled household, and especially of an old woman who regretted the death of her husband, because she said it would certainly 
have amused him. We slept on the ground on some straw, and returned to Heidelberg the next day in time for dinner. The following day we went to Mannheim to visit the theatre. It is very handsome and well appointed, and we were fortunate in happening upon an excellent opera. Beyond this, I saw nothing of Mannheim except the house of Kotzebue and the place where Sand was beheaded.

To-day I have made my visits to the professors. For three among them I had letter's from Professors Schinz and Hirzel. I was received by all in the kindest way. Professor Tiedemann, the Chancellor, is a man about the age of papa and young for his years. He is so well-known that I need not undertake his panegyric here. As soon as I told him that I brought a letter from Zurich, he showed me the greatest politeness, offered me books from his library; in one word, said he would be for me here what Professor Schinz, with whom he had formerly studied, had been for me in Zurich. After the opening of the term, when I know these gentlemen better, I will tell you more about them. I have still to describe my home, chamber, garden, people of the house, etc. 
The next letter fills in this frame-work.

TO HIS FATHER.

IIeidelberg, May 24, 1826.

...According to your request, I am going to write you all possible details about my host, the employment of my time, etc., etc. Mr. —_, my "philister," is a tobacco merchant in easy circumstances, having a pretty house in the faubourg of the city. My windows overlook the town, and my prospect is bounded by a hill situated to the north of Heidelberg. At the back of the house is a large and fine garden, at the foot of which is a very pretty summer-house. There are also several clumps of trees in the garden, and an aviary filled with native birds. . . .

Since each day in term time is only the repetition of every other, the account of one will give an idea of all, especially as I follow with regularity the plan of study I have formed. Every morning I rise at six o'clock, dress, and breakfast. At seven I go to my lectures, given during the morning in the Museum building, next to which is the anatomical laboratory. If; in the interval, I have a free hour, as sometimes happens from ten to eleven, I occupy it in making anatom. 
ical preparations. I shall tell you more of that and of the Museum another time. From twelve to one I practice fencing. We dine at about one o'clock, after which I walk till two, when I return to the house and to my studies till five o'clock. From five to six we have a lecture from the renowned Tiedemann. After that, I either take a bath in the Neckar or another walk. From eight to nine I resume my special work, and then, according to my inclination, go to the Swiss club, or,

- if I am tired, to bed. I have my evening service and talk silently with you, believing that at that hour you also do not forget your Louis, who thinks always of you. ... As soon as I know, for I cannot yet make an exact estimate, I will write you as nearly as possible what my expenses are likely to be. Sometimes there may be unlooked-for expenditures, as, for instance, six crowns for a matriculation paper. But be assured that at all events I shall restrict myself to what is absolutely necessary, and do my best to economize. The same of the probable duration of my stay in Heidelberg; I shall certainly not prolong it needlessly.

Now for the first time the paths of the 
two brothers separated, Auguste returning from Zurich to Neuchâtel, where he entered into business. It chanced, however, that in one of the first acquaintances made by Louis in Heidelberg he found not only a congenial comrade, but a friend for life, and in after years a brother. Professor Tiedemann, by whom Agassiz had been so kindly received, recommended him to seek the acquaintance of young Alexander Braun, an ardent student, and an especial lover of botany. At Tiedemann's lecture the next day Agassiz's attention was attracted by a young man who sat next him, and who was taking very careful notes and illustrating them. There was something very winning in his calm, gentle face, full of benevolence and intelligence. Convinced by his manner of listening to the lecture and transcribing it that this was the student of whom Tiedemann had spoken, Agassiz turned to his neighbor as they both rose at the close of the hour, and said, "Are you Alex. Braun?" "Yes, and you, Louis Agassiz?" It seems that Professor Tiedemann, who must have had a quick eye for affinities in the moral as well as in the physical world, had said to Braun also, that he advised him to make the acquaintance of a young Swiss natu. 
ralist who had just come, and who seemed full of enthusiasm for his work. The two young men left the lecture-room together, and from that time their studies, their excursions, their amusements, were undertaken and pursued in each other's company. In their long rambles, while they collected specimens in their different departments of Natural History, Braun learned zoölogy from Agassiz, and he, in his turn, learned botany from Braun. This was, perhaps, the reason why Alexander Braun, afterward Director of the Botanical Gardens in Berlin, knew more of zoölogy than other botanists, while Agassiz himself combined an extensive knowledge of botany with his study of the animal kingdom. That the attraction was mutual may be seen by the following extract from a letter of Alexander Braun to his father.

BRAUN TO HIS FATHER.

Heidelibrg, May 12, 1826.

... In my leisure hours, between the forenoon and afternoon lectures, I go to the dissecting-room, where, in company with another young naturalist who has appeared like a rare comet on the Heidelberg horizon, I dissect all manner of beasts, such as dogs, cats, birds, fishes, and even smaller fry, snails, but- 
terflies, caterpillars, worms, and the like. Beside this, we always have from Tiedemann the very best books for reference and comparison, for he has a fine library, especially rich in anatomical works, and is particularly friendly and obliging to us.

In the afternoon from two to three $I$ attend Geiger's lectures on pharmacentical chemistry, and from five to six those of Tiedemann on comparative anatomy. In the interval, I sometimes go with this naturalist, so recently arrived among us (his name is Agassiz, and he is from Orbe), on a hunt after animals and plants. Not only do we collect and learn to observe all manner of things, but we have also an opportunity of exchanging our views on scientific matters in general. I learn a great deal from him, for he is much more at home in zoölogy than I am. He is familiar with almost all the known mammalia, recognizes the birds from far off by their song, and can give a name to every fish in the water. In the morning we often stroll together through the fish market, where he explains to me all the different species. He is going to teach me how to stuff fishes, and then we intend to make a collection of all the native kinds. Many other useful things he knows; 
speaks German and French equally well, English and Italian fairly, so that I have already appointed him to be my interpreter on some future vacation trip to Italy. $\mathrm{He}$ is well acquainted with ancient languages also, and studies medicine besides. ...

A few lines from Braun to his mother, several weeks later, show that this first enthusiasm, poured out with half-laughing extravagance to his father, was ripening into friendship of a more serious character.

BRAUN TO HIS MOTHER.

Heidelberg, June 1, 1826.

... I am very happy now that I have found some one whose occupations are the same as mine. Before Agassiz came I was obliged to make my excursions almost always alone, and to study in hermit-like isolation. After all, two people working together can accomplish far more than either one can do alone. In order, for instance, to utilize the interval spent in the time-consuming and mechanical work of preparing specimens, pin- ning insects and the like, we have agreed that while one is so employed the other shall read aloud. In this way we shall go through 
various works on physiology, anatomy, and zoölogy. ...

Next to Alexander Braun, Agassiz's most congenial companion at Heidelberg was Karl Schimper, a friend of Braun, and like him a young botanist of brilliant promise. The three soon became inseparable. Agassiz had many friends and companions at the university beside those who, on account of their influence upon his after life, are mentioned here. He was too affectionate not to be a genial companion among his young countrymen of whom there were many at Heidelberg, where they had a club and a gymnasium of their own. In the latter, Agassiz bore his part in all the athletic sports, being distinguished both as a powerful gymnast and an expert fencer.

Of the professors then at Heidelberg, Leuckart, the zoölogist, was, perhaps, the most inspiriting. His lectures were full of original suggestions and clever hypotheses, which excited and sometimes amused his listeners. He knew how to take advantage of the enthusiasm of his brighter pupils, and, at their request, gave them a separate course of instruction on special groups of animals; not 
without some personal sacrifice, for these extra lectures were given at seven o'clock in the morning, and the students were often obliged to pull their professor out of bed for the purpose. The fact that they did so shows at least the friendly relation existing between teacher and scholars. With Bischoff the botanist also, the young friends were admitted to the most kindly intercourse. Many a pleasant botanical excursion they had with him, and they owed to him a thorough and skillful instruction in the use of the microscope, handled by him like a master. Tiedemann's lectures were very learned, and Agassiz always spoke of his old teacher in comparative anatomy and physiology with affectionate respect and admiration. He was not, however, an inspiring teacher, and though an excellent friend to the students, they had no such intimate personal relations with him as with Leuckart and Bischoff. From Bronn, the paleontologist, they received an immense amount of special information, but his instruction was minute in details rather than suggestive in ideas; and they were glad when their professor, finding that the course must be shortened for want of time, displayed to them his magnificent collection of fossils, and with the help 
of the specimens, developed his subject in a more general and practical way. ${ }^{1}$ Of the medical professors, Nägeli was the more interesting, though the reputation of Chelius brought him a larger audience. If there was however any lack of stimulus in the lecturerooms, the young friends made good the deficiency by their own indefatigable and intelligent study of nature, seeking to satisfy their craving for knowledge by every means within their reach. ${ }^{2}$

As the distance and expense made it impossible for Agassiz to spend his vacations with his family in Switzerland, it soon became the habit for him to pass the holidays with his new friend at Carlsruhe. For a young man of his tastes and acquirements a more charming home-life than the one to which he was here introduced can hardly be imagined. The

1 This collection was purchased in 1859 by the Museum of Comparative Zoölogy in Cambridge, Massachusetts, and Agassiz had thus the pleasure of teaching his American pupils from the very collection in which he had himself made his first important paleontological sturlies.

2 The material for this account of the student life of the two friends at Heidelberg and of their teachers was chiefly fnrnished by Alexander Braun himself at the close of his own life, after the death of Agassiz. The later sketches of the Professors at Munich in 1832 were drawn in great part from the same source. 
whole atmosphere was in harmony with the pursuits of the students. The house was simple in its appointments, but rich in books, music, and in all things stimulating to the thought and imagination. It stood near one of the city gates which opened into an extensive oak forest, in itself an admirable collecting ground for the naturalist. At the back certain rooms, sheltered by the spacious garden from the noise of the street, were devoted to science. In the first of these rooms the father's rich collection of minerals was arranged, and beyond this were the laboratories of his sons and their friends, where specimens of all sorts, dried and living plants, microscopes and books of reference, covered the working tables. Here they brought their treasures; here they drew, studied, dissected, arranged their specimens; here they discussed the theories, with which their young brains were teeming, about the growth, structure, and relations of animals and plants. ${ }^{1}$

From this house, which became a second home to Agassiz, he wrote to his father in the Christmas holidays of 1826: .. "My happiness would be perfect were it not for

1 See Biographical Memoir of Louis Agassiz, by Arnold Guyot, in the Froceedings of U. S. National Academy. 
the painful thought which pursues me everywhere, that I live on your privations; yet it is impossible for me to diminish my expenses farther. You would lift a great weight from my heart if you could relieve yourself of this burden by an arrangement with my uncle at Neuchâtel. I am confident that when I have finished my studies I could easily make enough to repay him. At all events, I know that you cannot pay the whole at once, and therefore in telling me frankly what are our resources for this object you would do me the greatest favor. Until I know that, I cannot be at peace. Otherwise, I am well, going on as usual, always working as hard as I can, and I believe all the professors whose lectures I attend are satisfied with me." . . . His father was also pleased with his conduct and with his progress, for about this time he writes to a friend, "We have the best possible news of Louis. Courageous, industrious, and discreet, he pursues honorably and vigorously his aim, namely, the degree of Doctor of Medicine and Surgery."

In the spring of 1827 Agassiz fell ill of a typhus fever prevalent at the university as an epidemic. His life was in danger for many days. As soon as he could be moved, Braun 
took him to Carlsruhe, where his convalescence was carefully watched over by his friend's mother. Being still delicate he was advised to recruit in his native air, and he returned to Orbe, accompanied by Braun, who did not leave him till he had placed him in safety with his parents, The following extracts from the correspondence between himself and Braun give some account of this interval spent at home.

AGASSIZ TO BRAUN.

Orbe, May 26, 1827.

- . Since I have been here, I have walked faithfully and have collected a good number of plants which are not yet dry. I have more than one hundred kinds, about twenty specimens of each. As soon as they can be taken out of the press, I'll send you a few specimens of each kind with a number attached so that you may identify them. Take care that you do not displace the numbers in opening the package. Should you want more of any particular kind let me know; also whether Schimper wishes for any. .... At Neuchâtel I had the good fortune to find at least thirty specimens of Bombinator obstetricans with the eggs. Tell Dr. Leuckart that YOL. I. 
I. will bring him some, - and some for you also. I kept several alive laid in damp moss; after fourteon days the eggrs were almost as large as prats, and the little tadpoles moved about inside in all directions. The mother stripped the exgrs from her legs, and one of the little tadpoles came out, but died for want of water. Then I placed the whole mass of eggrs in a vessel filled with water, and behold! in about; an hour some twenty young ones were swimming freely about. I shall spare no pains to raise them, and I hope, if I begin aright, to make fine toads of them in the end. My oldest sister is busy every day in making drawings for me to illustrate their gradual development. . . I dissect now as much and on as great a variety of subjects as possible. 'This makes my principal oceupation. I an often busy too with Oken. His "Natur-philosophie" gives me the greatest pleasure. I long for my box, being in need of my books, which, no doubt, you have sent. Meantime, I am reading something of Universal Mistory, and am not idle, as you see. But I miss the evenimgs with you and Schimper at Heidelberg, and wish I were with you once more. I am afraid when that happy time does come, it will be only too short. . . . 
BRAUN TO AGASSIZ.

Heidelberg, May, 1827.

-. On Thursday evening, the 10th, I reached Heidelberg. The medical lectures did not begin till the second week of May; so that I have missed little, and almost regret having returned so soon.... I passed the last afternoon in Basel very pleasantly with Herr Roepper, to whom I must soon write. He gave me a variety of specimens, showed. me many beautiful things, and told me much that was instructive. He is a genuine and excellent botanist, and no mere collector like the majority. Neither is he purely an observer like Dr. Bischoff, but a man who thinks. . . . Dr. Leuckart is in raptures about the eggs of the "Hebammen Kröte," and will raise them. .. Schweiz takes your place in our erudite evening meetings. I have been lecturing lately on the metamorphosis of plants, and Schimper has propounded an entirely new and very interesting theory, which will, no doubt, find favor with you hereafter, about the significance of the circular and longitudinal fibres in organisms. Schimper is fruitful as ever in poetical and philosophical ideas, and has just now ventured upon a natural history of the mind. We 
have introduced mathematics also, and he has advanced a new hypothesis about comets and their long tails. ... Our chief botanical occupation this summer is the careful observation of all our plants, even the commonest, and the explanation of whatever is unusual or enigmatical in their structure. We have already cracked several such nuts, but many remain to be opened. All such puzzling specimens are spread on single sheets and set aside. - . But more of this when we are together again. . . Dr. Leuckart begs you to study carefully the "Hebammen Unke;" 1 to notice whether the eggs are already fecundated when they are in the earth, or whether they copulate later in the water, or whether the young are hatched on land, and what is their tadpole condition, etc. All this is still unknown....

AGASSIZ TO BRAUN.

ORBE, June 10, 1827.

... Last week I made a very pleasant excursion. You will remember that I have often spoken to you of Pastor Mellet at Vallorbe, who is much interested in the study of the six-legged insects. He invited me to go

1 Bombinator obstetricans referred to in a former letter. 
to Vallorbe with him for some days, and I passed a week there, spending my time most agreeably. We went daily on a search after insects ; the booty was especially rich in beetles and butterflies. ... I examined also M. Mellet's own most excellent collection of beetles and butterflies very carefully. He has many beautiful things, but almost exclusively Swiss or French, with a few from Brazil, - in all about 3,000 species. He gave me several, and promises more in the autumn. ... He knows his beetles thoroughly, and observes their habits, haunts, and changes (as far as he can) admirably well. It is a pity though that while his knowledge of species is so accurate, he knows nothing of distribution, classification, or general relations. I tried to convince him that he ought to collect snails, slugs, and other objects of natural history, in the hope that he might gain thereby a wider insight. But he would not listen to it; he said he had enough to do with his Vermine.

My brother writes me that my box has arrived in Neuchâtel. As I am going there soon I will take it then. I rejoice in the thought of being in Neuchâtel, partly on account of my brother, Arnold (Guyot), and other friends, and partly that I may study the 
fishes of our Swiss lakes. The species Cyprinus and Corregonus with their allies, including Salmo, are, as you know, especially difficult. I will preserve some small specimens in alcohol, and, if possible, dissect one of each, in order to satisfy myself as to their identity or specific variety. As the same kinds have received different names in different lakes, and since even differences of age have led to distinct designations, I will note all this down carefully. When I have made it clear to myself, I will send you a catalogue of the linds we possess, specifying at the same time the lakes in which they occur. As I am on the chapter of fishes, I will ask you : 1. What are the gill arches? 2. What the gill blades? 3 . What is the bladder in fishes? 4. What is the cloaca in the egg-laying animals? 5 . What signify the many fins of fishes? 6 . What is the sac which surrounds the eggs in Bombinator obstetricans ? . . Tell Dr. Leuckart I have already put aside for him the Corregonus umbla (if such it be), but can get no Silurus glanis.

I suppose you continue to come together now and then in the evening. . . Make me a sharer in your new discoveries. Have you finished your essay on the physiology of plants, and what do you make of it? . . . 
CORRESPONDENCE WITH BRAUN. 39

BRAUN TO AGASSIZ.

Carlsruhe, Whitsuntide, Monday, 1827.

... I am in Carlsruhe, and as the package has not gone yet, I add a note. I have been analyzing and comparing all sorts of plants in our garden to-day, and I wish you had been with me. On my last sheet I send some nuts for you to pick, some wholly, some half, others not at all, cracked. Schimper is lost in the great impenetrable world of suns, with their planets, moons, and comets; he soars even into the region of the double stars, the milky way, and the nebulæ.

On a loose sheet come the "nuts to pick." It contains a long list of mooted questions, a few of which are given here to show the exchange of thought between Agassiz and his friend, the one propounding zoölogical, the other botanical, puzzles. Although most of the problems were solved long ago, it is not uninteresting to follow these young minds in their search after the laws of structure and growth, dimly pcrceived at first, but becoming gradually clearer as they go on. The very first questions hint at the law of Phyllotaxis, then wholly unknown, though now it makes 
a part of the most elementary instruction in botany. ${ }^{1}$

" 1 . Where is the first diverging point of the stems and roots in plants, that is to say, the first geniculum?

"2. How do you explain the origin of those leaves on the stem which, not arising from distinct geniculi, are placed spirally or scattered around the stem?

"3. Why do some plants, especially trees (contrary to the ordinary course of development in plants), blossom before they have put forth leaves? (Elm-trees, willow-trees, and fruit-trees.)

"4. In what succession does the development of the organs of the flower take place? - and their formation in the bud? (Compare Campanula, Papaver.)

"5. What are the leaves of the Spergula?

"6. What are the tufted leaves of various pine-trees? (Pinus sylvestris, Strobus, Larix, etc.) ...

"18. What is individuality in plants?"

The next letter contains Agassiz's answer to

1 Botany owes to Alexander Braun and Karl Schimper the discovery of this law, by which leaves, bowever crowded, are so arranged around the stem as to divide the space with mathematical precision, thus giving to each leaf its fair share of room for growth. 
Dr. Leuckart's questions concerning the eggs he had sent him, and some farther account of his own observations upon them.

AGASSIZ TO BRAUN.

NeuCnÂtel, June 20, 1827.

... Now you shall hear what I know of the "Hebammen Kröte." How the fecundation takes place I know not, but it must needs be the same as in other kinds of the related Bombinator; igneus throws out almost as many eggs hanging together in clusters as obstetricans; fuscus throws them out from itself in strings (see Röseld's illustration). . . . I have now carefully examined the egg clusters of obstetricans; all the eggs are in one string and hang together. This string is a bag, in which the eggs lie inclosed at different distances, though they seem in the empty space to be fallen, thread-like, together. But if you stretch the thread and press the eggs, they change their places, and you can distinctly see that they lie free in the bag, having their own membranous envelopes corresponding to those of other batrachian eggs. Surely this species seeks the water at the time of fecundation, for so do all batrachians, the water being indeed a more fitting medium for fecundation 
than tho air. . . It is certain that the eggrs were already fecundated when we found them in the ground, for later, I found several not so far advanced as those you have, and yet after three weeks I had tadpoles from them. In those eggs which were in the lowest stage of development (how they may be earlier, nescio), nothing was clearly visible; they were simply little yellow balls. After some days, two small dark spots were to be seen marking the position of the eyes, and a longitudinal streak indicated the dorsal ridge. Presently everything became more distinct; the mouth and the nasal opening, the eyes and the tail, which lay in a half circle around

- the body; the skin was so transparent that the beating of the heart and the blood in the vessels could be easily distinguished; the yolk and the yolk sac were meanwhile sensibly diminished. The movements of the little animal were now quite perceptible, - they were quick and by starts. After three or four weeks the eggs were as large as peas; the bags had burst at the spots where the eggs were attached, and the little creatures filled the egg envelopes completely. They moved incessantly and very quickly. Now the female stripped off the eggs from her legs; she 
seemed very uneasy, and sprang about constantly in the tank, but grew more quiet when I threw in more water. The eggs were soon free, and I laid them in a shallow vessel filled with fresh water. The restlessness among them now became greater, and behold! like lightning, a little tadpole slipped out of its egg, paused astonished, gazed on the greatness of the world, made some philanthropic observations, and swam quickly away. I gave them fresh water often, and tender green plants as well as bread to eat. They ate eagerly. Up to this time their different stages of development had been carefully drawn by my sister. I now went to Vallorbe; they promised at home to take care of my young brcod, but when I returned the tadpoles had been forgotten, and I found them all dead; not yet decayed, however, and I could therefore preserve them in alcohol. The gills I have never seen, but I will watch to see whether they are turned inward. . . .

BRAUN TO AGASSIZ.

Carlsruhe, August 9, 1827.

... This is to tell you that I have determined to leave Heidelberg in the autumn and set forth on a pilgrimage to Munich, and that 
I invite you to be my traveling companion. Judging by a circumstantial letter from Döllinger, the instruction in the natural sciences leaves nothing to be desired there. Add to this that the lectures are free, and the theatre open to students at twenty-four kreutzers. No lack of advantages and attractions, lodgings hardly more expensive than at Heidelberg, board equally cheap, beer plenty and good. Let all this persuade you. We shall hear Gruithuisen in popular astronomy, Schubert in general natural history, Martius in botany, Fuchs in mineralogy, Seiber in mathematics, Starke in physics, Oken in everything (he lectures in winter on the philosophy of nature, natural history, and physiology). The clinical instruction will be good. We shall soon be friends with all the professors. The library contains whatever is best in botany and zoölogy, and the collections open to the public are very rich. It is not known whether Schelling will lecture, but at all events certain of the courses will be of great advantage. Then little vacation trips to the Salzburg and Carinthian Alps are easily made from there! Write soon whether you will go and drink Bavarian beer and Schnapski with me, and write also when we are to see you in Heidelberg and 
Carlsruhe. Remind me then to tell you about the theory of the root and poles in plants. As soon as I have your answer we will bespeak our lodgings from Döllinger, who will attend to that for us. Shall we again house together in one room, or shall we have separate cells in one comb, namely, under the same roof? The latter has its advantages for grassgatherers and stone-cutters like ourselves.... Hammer away industriously at all sorts of rocks. I have collected at Auerbach, Weinheim, Wiesloch, etc. But before all else, observe carefully and often the wonderful structure of plants, those lovely children of the earth and sky. Ponder them with child-like mind, for children marvel at the phenomena of nature, while grown people often think themselves too wise to wonder, and yet they know little more than the children. But the thoughtful student recognizes the truth of the child's feeling, and with his knowledge of nature his wonder does but grow more and more. . . 


\section{CHAPTER II.}

$$
1827-1828 \text { : ÆT. } 20-21 .
$$

Arrival in Munich. - Lectures. - Relations with the Professors. - Schelling, Martius, Oken, Döllinger. - Relations with Fellow-Students. - The Little Academy. - Plans for Traveling. - Advice from his Parents. - Vacation Journey. - Tri-Centemial Dürer Festival at Nuremberg.

Agassiz accepted with delight his friend's proposition, and toward the end of October, 1827, he and Braun left Carlsruhe together for the University of Munich. His first letter to his brother is given in full, for though it contains crudities at which the writer himself would have smiled in after life, it is interesting as showing what was the knowledge possessed in those days by a clever, well-informed student of natural history.

TO HIS BROTHER AUGUSTE.

Munich, November 5, 1827.

... At last I am in Munich. I have so much to tell you that I hardly know where to begin. To be sure that I forget nothing, 
however, I will give things in their regular sequence. First, then, the story of my journey; after that, I will tell you what I am doing here. As papa has, of course, shown you my last letter, I will continue where I left off. . . .

From Carlsruhe we traveled post to Stuttgart, where we passed the greater part of the day in the Museum, in which I saw many things quite new to me; a llama, for instance, almost as large as an ass. You know that this animal, which is of the genus Camelus, lives in South America, where it is to the natives what the camel is to the Arab; that is to say, it provides them with milk, wool, and meat, and is used by them, moreover, for driving and riding. There was a North American buffalo of immense size; also an elephant from Africa, and one from Asia; beside these, a prodigious number of gazelles, deer, cats, and dogs; skeletons of a hippopotamus and an elephant; and lastly the fossil bones of a mammoth. You know that the mammoth is no longer found living, and that the remains hitherto discovered lead to the belief that it was a species of carnivorous elephant. It is a singular fact that some fishermen, digging recently on the borders of the Obi, in Siberia, found one of these animals 
frozen in a mass of ice, at a depth of sixty feet, so well preserved that it was still covered with hair, as in life. They melted the ice to remove the animal, but the skeleton alone remained complete; the hide was spoiled by contact with the air, and only a few pieces have been kept, one of which is in the Museum at Stuttgart. The hairs upon it are as coarse as fine twine, and nearly a foot long. The entire skeleton is at St. Petersburg in the Museum, and is larger than the largest elephant. One may judge by that what havoc such an animal must have made, if it was, as its teeth show it to have been, carnivorous. But what I would lilse to know is how this animal could wander so far north, and then in what manner it died, to be frozen thus, and remain intact, without decomposing, perhaps for countless ages. For it must have belonged to a former creation, since it is nowhere to be found living, and we have no instance of the disappearance of any kind of animal within the historic period. There were, besides, many other kinds of fossil animals. The collection of birds is very beautiful, but it is a pity that many of them are wrongly named. I corrected a number myself. . . . From Stuttgart we went to Esslingen, where we 
were to visit two famous botanists. One was Herr Steudel; a sombre face, with long overhanging black hair, almost hiding the eyes, - a very Jewish face. He knows every book on botany that appears, has read them all, but cares little to see the plants themselves; in short, he is a true closet student. He has a large herbarium, composed in great part of plants purchased or received as gifts. The other, Professor Hochstetter, is an odd little man, stepping briskly about in his high boots, and having always a half suppressed smile on his lips whenever he takes the pipe from between his teeth. A very good man, however, and extremely obliging; he offered us every civility. As we desired not only to make their acquaintance, but to win from these botanists at least a few grasses, we presented ourselves like true commis voyageurs, with dried herbs to sell, each of us having a package of plants under his arm, - mine being Swiss, gathered last summer, Braun's from the $\mathrm{Pa}$ latinate. We gave specimens to each, and received in exchange from Steudel some American plants; from Hochstetter some from Bohemia, and others from Moravia, his native country. From Esslingen we were driven to Goeppingen, in the most frightful weather vor. 1. 
possible; it rained, snowed, froze, blew, all at once. It was a pity, since our road lay through one of the prettiest valleys I have ever seen, watered by the Neckar, and bordered on both sides by mountains of singular form and of considerable height. They are what the Wuirtembergers call the Suabian Alps, but I think that Chaumont is higher than the loftiest peak of their Alps. Here we found an old Heidelberg acquaintance, whose father owns a superb collection of fossils, especially of shells and zoöphytes. He has also quite a large collection of shells from the Adriatic Sea, but among these last not one was named. As we knew them, we made it our duty to arrange them, and in three hours his whole collection was labeled. Since he has duplicates of almost everything, he promised, as soon as he should have time, to make a selection from these and send them to us. Could we have stayed longer we might have picked out what we pleased, for he placed his collection at our disposal. But we were in haste to arrive here, so we begged him to send us, at his leisure, whatever he could give us.

Thence we continued our journey by post, because it still rained, and the roads were so detestable that with the best will in the world 
we could not have made our way on foot. In the evening we reached Ulm, where, owing to the late hour, we saw almost nothing except the famous belfry of the cathedral, which was distinctly visible as we entered the city. After supper we continued our journey, still by post, wishing to be in Munich the next day. I have never seen anything more beautiful than the view as we left Ulm. The moon had risen and shone upon the belfry like broad daylight. On all sides extended a wide plain, unbroken by a single inequality, so far as the eye could distinguish, and cut by the Danube, glittering in the moonbeams. We crossed the plain during the night, and reached Augsburg at dawn. It is a beautiful city, but we merely stopped there for breakfast, and saw the streets only as we passed through them. On leaving Augsburg, the Tyrolean Alps, though nearly forty leagues away, were in sight. About eighteen leagues off was also discernible an immense forest; of this we had a nearer view as we advanced, for it encircles Munich at some distance from the town. We arrived here on Sunday, the 4 th, in the afternoon. . . My address is opposite the Sendlinger Thor No. 37. I have a very pretty chamber on the lower floor with an al- 
cove for my bed. The house is situated outside the town, on a promenade, which makes it very pleasant. Moreover, by walking less than a hundred yards, I reach the Hospital and the Anatomical School, - a great convenience for me when the winter weather begins. One thing gives me great pleasure : from one of my windows the whole chain of the Tyrolean Alps is visible as far as Appenzell ; and as the country is flat to their very base, I see them better than we see our Alps from the plain. It is a great pleasure to have at least a part of our Swiss mountains always in sight. - To enjoy it the more, I have placed my table opposite the window, so that every time I lift my head my eyes rest on our dear country. This does not prevent me from feeling dull sometimes, especially when I am alone, but I hope this will pass off when my occupations become more regular. . . .

A far more stimulating intellectual life than that of Heidelberg awaited our students at Munich. Among their professors were some of the most original men of the day, - men whose influence was felt all over Europe. Döllinger lectured on comparative anatomy and kindred subjects; Martius and Zuccarini 
on botany. Martius gave, besides, his socalled "Reise-Colleg," in which he instructed the students how to observe while on their travels. Schelling taught philosophy, the titles of his courses in the first term being, "Introduction to Philosophy" and "The Ages of the World"; in the second, "The Philosophy of Mythology" and "The Philosophy of Revelation." Schelling made a strong impression upon the friends. His manner was as persuasive as his style was clear, and his mode of developing his subject led his hearers along with a subtle power which did not permit fatigue. Oken lectured on general natural history, physiology, and zoölogy, including his famous views on the philosophy of nature (Natur-philosophie). His lectures gave occasion for much scientific discussion, the more so as he brought very startling hypotheses into his physiology, and drew from them conclusions which even upon his own showing were not always in accordance with experience. "On philosophical grounds," he was wont to say, when facts and theory thus confronted each other, "we must so accept it." Oken was extremely friendly with the students, and Agassiz, Braun, and Schimper (who joined them at Munich) passed an evening 
once a week at his house, where they listened to scientific papers or discussed scientific matters, over a pipe and a glass of beer. They also met once a week to drink tea at the house of Professor von Martius, where, in like manner, the conversation turned upon scientific subjects, unless something interesting in general events gave it a different turn. Still more beloved was Döllinger, whose character they greatly esteemed and admired while they delighted in his instruction. Not only did they go to him daily, but he also came often to see them, bringing botanical specimens to Braun, or looking in upon Agassiz's breeding experiments, in which he took the liveliest interest, being always ready with advice or practical aid. The fact that Agassiz and Braun had their room in his house made intercourse with him especially easy. This room became the rendezvous of all the aspiring, active spirits among the young naturalists at Munich, and was known by the name of "The Little Academy." Schimper, no less than the other two, contributed to the rivid, enthusiastic intellectual life, which characterized their meetings. Not so happy as Agassiz and Braun in his later experience, the promise of his youth was equally brilliant; 
and those who knew him in those early days remember his charm of mind and manner with delight. The friends gave lectures in turn on various subjects, especially on modes of development in plants and animals. These lectures were attended not only by students, but often by the professors.

Among Agassiz's intimate friends in $\mathrm{Mu}$ nich, beside those already mentioned, was $\mathrm{Mi}$ chahelles, the distinguished young zoölogist and physician, whose early death in Greece, where he went to practice medicine, was so much regretted. Like Agassiz, he was wont to turn his room into a menagerie, where he kept turtles and other animals, brought home, for the most part, from his journeys in Italy and elsewhere. Mahir, whose name occurs often in the letters of this period, was another college friend and fellow-student, though seemingly Agassiz's senior in standing, if not in years, for he gave him private instruction in mathematics, and also assisted him in his medical studies.

TO HIS SISTER CECILE.

Munich, November 20, 1827.

. . I I will tell you in detail how my time is spent, so that when you think of me you 
may know where $I$ am and what $I$ am doing. In the morning from seven to nine I am at the Hospital. From nine to eleven I go to the Library, where I usually work at that time instead of going home. From eleven till one o'clock I have lectures, after which I dine, sometimes at one place, sometimes at another, for here every one, that is, every foreigner, takes his meals in the cafes, paying for the dinner on the spot, so that he is not obliged to go always to the same place. In the afternoon I have other lectures on various subjects, according to the days, from two or three till five o'clock. These ended, I take a walk although it is then dark. The environs of Munich are covered with snow, and the people have been going about in sleighs these three weeks. When I am frozen through I come home, and set to work to review my lectures of the day, or I write and read till eight or nine o'clock. Then I go to my café for supper. After supper I am glad to return to the house and go to bed.

This is the course of my daily life, with the single exception that sometimes Braun and I pass an evening with some professor, discussing with all our might and main subjects of which we often know nothing; this 
does not, however, lessen the animation of the talk. More often, these gentlemen tell us of their travels, etc. I enjoy especially our visits to M. Martius, because he talks to us of his journey to Brazil, from which he returned some years ago, bringing magnificent collections, which he shows us whenever we call upon him. Friday is market day here, and I never miss going to see the fishes to increase my collection. I have already obtained several not to be found in Switzerland; and even in my short stay here I have had the good fortune to discover a new species, of which I have made a very exact description, to be printed in some journal of natural history. Were my dear Cecile here, I should have begged her to draw it nicely for me. That would have been pleasant indeed. Now I must ask a stranger to do it, and it will have by no means the same value in my eyes. ...

TO HIS BROTHER AUGUSTE.

Munich, December 26, 1827.

. . After my long fast from news of you, your letter made me very happy. I was dull besides, and needed something to cheer me. . . Since my talk about natural history does not bore you, I want to tell you various 
other things about it, and also to ask you to do me a favor. I have stuffed a superb otter lately; next week I shall receive a beaver, and I have exchanged all my little toads from Neuchâtel for reptiles from Brazil and Java. One of our professors here, who is publishing a natural history of reptiles, will introduce in his work my description of that species, and my observations upon it. He has already had lithographed those drawings of eggs that Cecile made for me, as well as the colored drawings made for me by Braun's sister when I was at Carlsruhe. My collection of fishes is also much increased, but I have no duplicates left of the species I brought with me. I have exchanged them all. I should therefore be greatly obliged if you would get me some more of the same. I will tell you what kinds I want, and how you are to forward them. I have still at Cudrefin several jars of thick green glass. When you go there take them away with you, fill them with alcohol, and put into them as many of these fishes as you can find for me. Put something between every two specimens, to prevent them from rubbing against each other; pack them in a little box wrapped in hay, and send them either by a good opportunity or in the least 
expensive way. The kinds I want are [here follows the list]. ... It will interest you to know that I am working with a young Dr. Born upon an anatomy and natural history of the fresh-water fishes of Europe. We have already gathered a great deal of material, and I think by the spring, or in the course of the summer, we shall be able to publish the first number. This will bring in a little ready money for a short journey in the vacation.

I earnestly advise you to while away your leisure hours with study. Read much, but only good and useful books. I promised to send you something; do not think, because I have not done so yet, that I have forgotten it. On the contrary, the difficulty of choosing is the cause of the delay; but I will make farther inquiry as to what will suit you best and you shall have my list. Meantime remember to read Say, and if you have not already begun it, do not put it off. Remember that statistical and political knowledge alone distinguishes the true merchant from the mere tradesman, and guides him in his undertakings. . . A merchant familiar with the products of a country, its resources, its commercial and political relations with other countries, is much less likely to enter 
into speculations based on false ideas, and therefore of doubtful issue. Write me about what you are reading and about your plans and projects, for I can hardly believe that any one could exist without forming them: I, at least, could not. ...

The last line of this letter betrays the restless spirit of adventure growing out of the desire for larger fields of activity and research. Tranquilized for a while in the new and more satisfying intellectual life of Munich, it stirred afresh from time to time, not without arousing anxiety in friends at home, as we shall see. The letter to which the following is an answer has not been found.

FROM HIS MOTHER.

ORBE, January 8, 1828.

... Your letter reached me at Cudrefin, where I have been passing ten days. With what pleasure I received it, - and yet I read it with a certain sadness too, for there was something of ennui, I might say of discontent, in the tone. . . Believe me, my dear Louis, your attitude is a wrong one; you see everything in shadow. Consider that you are exactly in the position you have chosen for 
yourself; we have in no way opposed your plans. We have, on the contrary, entered into them with readiness, saying amen to your proposals, only insisting upon a profession that would make us easy about your future, persuaded as we are that you have too much energy and uprightness not to wish to fill honorably your place in society. You left us a few months ago with the assurance that two years would more than suffice to complete your medical studies. You chose the university which offered, as you thought, the most ample means to reach your end; and now, how is it that you look forward only with distaste to the practice of medicine? Have you reflected seriously before setting aside this profession? Indeed, we cannot consent to such a step. You would lose ground in our opinion, in that of your family, and in that of the public. You would pass for an inconsiderate, fickle young fellow, and the slightest stain on your reputation would be a mortal blow to us. There is one way of reconciling all difficulties, - the only one in my opinion. Complete your studies with all the zeal of which you are capable, and then, if you have still the same inclination, go on with your natural history; give yourself wholly up to it 
should that be your wish. Having two strings to your bow, you will have the greater facility for establishing yourself. Such is your father's way of thinking as well as mine. . . . Nor are you. made to live alone, my child. In a home only is true happiness to be found; there you can settle yourself to your liking. The sooner you have finished your studies, the sooner you can put up your tent, catch your blue butterfly, and metamorphose her into a loving housewife. Of course you will not gather roses without thorns; life consists of pains and pleasures everywhere. To do all the good you can to your fellow-beings, to have a pure conscience, to gain an honorable livelihood, to procure for yourself by work a little ease, to make those around you happy, - that is true happiness; all the rest but mere accessories and chimeras. . . .

TO HIS MOTHER.

Munich, February 3, 1828.

... You know well to whom you speak, dear mother, and how you must bait your hook in order that the fish may rise. When you paint it, I see nothing above domestic happiness, and am convinced that the height of felicity is to be found in the bosom of your 
family, surrounded by little marmots to love and caress you. I hope, too, to enjoy this happiness in time.... But the man of letters should seek repose only when he has deserved it by his toil, for if once he anchor himself, farewell to energy and liberty, by which alone great minds are fostered. Therefore I have said to myself, that I would remain unmarried till my work should assure me a peaceful and happy future. A young man has too much vigor to bear confinement so soon; he gives up many pleasures which he might have had, and does not appreciate at their just value those which he has. As it is said that the vaurien must precede the bon sujet, so I believe that for the full enjoyment of sedentary life one must have played the vagabond for a while.

This brings me to the subject of my last letter. It seems that you have misunderstood me, for your answer grants me after all just what I ask. You think that I wish to renounce entirely the study of medicine? On the contrary, the idea has never occurred to me, and, according to my promise, you shall have one of these days a doctor of medicine as a son. What repels me is the thought of practicing medicine for a livelihood, and here 
you give me free rein just where I wanted it. That is, you consent that I should devote myself wholly to the natural sciences should this career offer me, as I hope it may, a more favorable prospect. It requires, for instance, but two or three years to go around the world at government expense. I will levy contributions on all my senses that not a single chance may escape me for making interesting observations and fine collections, so that $I$ also may be ranked among those who have enlarged the boundaries of science. With that my future is secured, and I shall return content and disposed to do all that you wish. Even then, if medicine had gained greater attraction for me, there wonld still be time to begin the practice of it. It seems to me there is nothing impracticable in this plan. I beg you to think of it, and to talk it over with papa and with my uncle at Lausanne. . . . I am perfectly well and as happy as possible, for I feed in clover here on my favorite studies, with every facility at my command. If you thought my New Year's letter depressed, it was only a momentary gloom due to the memories awakened by the day. . . . 
FROM HIS FATHER.

Orbe, February 21, 1828.

Your mother's last letter, my dear Louis, was in answer to one from you which crossed it on the way, and gave us, so far as your health and contentment are concerned, great satisfaction. Yet our gratification lacks something; it would be more complete had you not a mania for rushing full gallop into the future. I have often reproved you for this, and you would fare better did you pay more attention to my reproof. If it be an incurable malady with you, at all events do not force your parents to share it. If it be $a b$ solutely essential to your happiness that you should break the ice of the two poles in order to find the hairs of a mammoth, or that you should dry your shirt in the sun of the tropics, at least wait till your trunk is packed and your passports are signed before you talk with us about it. Begin by reaching your first aim, a physician's and surgeon's diploma. I will not for the present hear of anything else, and that is more than enough. Talk to us, then in your letters, of your friends, of your personal life, of your wants (which I am always ready to satisfy), of your pleasures, of VOL. 1 . 
your feeling for us, but do not put yourself out of our reach with your philosophical syllogisms. My own philosophy is to fulfill my duties in my sphere, and even that gives me more than I can do. ...

The Vaudois "Society of Public Utility" has just announced an altogether new project, that of establishing popular libraries. A committee consisting of eight members, of whom I have the honor to be one, is nominated under the presidency of M. Delessert for the execution of this scheme. What do you think of the idea? To me it seems a delicate matter. I should say that before we insist upon making people read we must begin by preparing them to read usefully? ...

TO HIS FATHER.

Munich, March 3, 1828.

... What you tell me of the "Society of Public Utility" has aroused in me a throng of ideas, about which I will write you when they are a little more mature. Meanwhile, please tell me: 1. What is this Society? 2. Of what persons is it composed? 3 . What is its principal aim? 4. What are the popular libraries to contain, and for what class are they intended? I believe this project may be of 
the greatest service to our people, and it is on this account that I desire farther details that I may think it over carefully. Tell me, also, in what way you propose to distribute your libraries at small expense, and how large they are to be. ...

I could not be more satisfied than I am with my stay here. I lead a monotonous but an exceedingly pleasant life, withdrawn from the crowd of students and seeing them but little. When our lectures are over we meet in the evening at Braun's room or mine, with three or four intimate acquaintances, and talk of scientific matters, each one in his turn presenting a subject which is first developed by him, and then discussed by all. These exercises are very instructive. As my share, I have begun to give a course of natural history, or rather of pure zoölogy. Braun talks to us of botany, and another of our company, Mahir, who is an excellent fellow, teaches us mathematics and physics in his turn. In two months our friend Schimper, whom we left at Heidelberg, will join us, and he will then be our professor of philosophy. Thus we shall form a little university, instructing each other and at the same time learning what we teach more thoroughly, because we shall be obliged 
to demonstrate it. Each session lasts two or three hours, during which the professor in charge retails his merchandise without aid of notes or book. You can imagine how useful this must be in preparing us to speak in public and with coherence; the experience is the more important, since we all desire nothing so much as sooner or later to become professors in very truth, after having played at professor in the university.

This brings me naturally to my projects again. Your letter made me feel so keenly the anxiety I had caused you by my passion for travel, that I will not recur to it; but as my object was to make in that way a name that would win for me a professorship, I venture upon another proposition. If during the course of my studies I succeed in making myself known by a work of distinction, will you not then consent that I shall study, at least during one year, the natural sciences alone, and then accept a professorship of natural history, with the understanding that in the first place, and in the time agreed upon, I shall take my Doctor's degree? This is, indeed, essential to my obtaining what I wish, at least in Germany. You will object that, before thinking of anything beyond, I ought first to 
fulfill the condition. But let me say that the more clearly a man sees the road before him, the less likely he is to lose his way or take the wrong turn, - the better he can divide his stages and his resting-places. ...

FROM HIS FATHER.

Orbe, March 25, 1828.

... I have had a long talk about you with your uncle. He does not at all disapprove of your letter's, of which I told him the contents. He only insists, as we do, on the necessity of a settled profession as absolutely essential to your financial position. Indeed, the natural sciences, however sublime and attractive, offer nothing certain in the future. They may, no doubt, be your golden bridge, or you may, thanks to them, soar very high, but - modern Icarus - may not also some adverse fortune, an unexpected loss of popularity, or, perhaps, some revolution fatal to your philosophy, bring you down with a somersault, and then you would not be sorry to find in your quiver the means of gaining your bread. Agreed that you have now an invincible repugnance to the practice of medicine, it is evident from your last two letters that you would have no less objection to any 
other profession by which money is to be made, and, besides, it is too late to make another selection. This being so, we will come to an understanding in one word: Let the sciences be the balloon in which you prepare to travel through higher regions, but let medicine and surgery be your parachutes. I think, my dear Louis, you cannot object to this way of looking at the question and deciding it. In making my respects to the professor of zoölogy, I have the pleasure to tell him that his uncle was delighted with his way of passing his evenings, and congratulates him with all his heart on his choice of a recreation. Enough of this chapter. I close it here, wishing you most heartily courage, health, success, and, above all, contentment. . . .

Upon this follows the answer to Louis's request for details about the "Society of Public Utility." It shows the intimate exchange of thought between father and son on educational subjects, but it is of too local an interest for reproduction here.

The Easter vacation was devoted to a short journey, some account of which will be found in the next letter. The traveling party consisted of Agassiz, Braun, and Schimper, with 
two other students, who did not, however, remain with them during the whole trip.

TO HIS FATHER.

Munich, May 15, 1828.

. . Pleasant as my Easter journey was, I will give you but a brief account of it, for my enjoyment was so connected with my special studies that the details would only be tiresome to you. You know who were my traveling companions, so I have only to tell you of our adventures, assuredly not those of knights errant or troubadours. Could these gentry have been resuscitated, and have seen us starting forth in blouses, with bags or botanical boxes at our backs and butterfly-nets in our hands, instead of lance and buckler, they could hardly have failed to look down upon us with pity from the height of their grandeur.

The first day brought us to Landshut, where was formerly the university till it was transferred, ten years ago, to Munich. We had the pleasure of finding along our road most of the early spring plants. The weather was magnificent, and nature seemed to smile upon her votaries.... We stopped on the way but one day, at Ratisbon, to visit some 
relations of Braun's, with whom we promised to spend several days on our return. Learning on our arrival at Nüremberg that the Dürer festival, which had been our chief inducement for this journey, would not take place under eight or ten days, we decided to pass the intervening time at Erlangen, the seat, as you know, of a university. I do not know if I have already told you that among German students the exercise of hospitality toward those who exchange visits from one university to another is a sacred custom. It gives offense, or is at least looked upon as a mark of pride and disdain, if you do not avail yourself of this. We therefore went to one of the cafés de réunion, and received at once our tickets for lodgings. We passed six days at Erlangen most agreeably, making a botanical excursion every day. We also called upon the professors of botany and zoölogy, whom we had already seen at Munich, and by whom we were most cordially received. The professor of botany, M. Koch, invited us to a very excellent dinner, and gave us many rare plants not in our possession before, while M. Wagner was kind enough to show us in detail the Museum and the Library.

At last came the day appointed for the 
third centennial festival of Dürer. Everything was so arranged as to make it very brilliant, and the weather was most favorable. I doubt if ever before were collected so many painters in the same place. They gathered, as if to vie with each other, from all nations, Russians, Italians, French, Germans, etc. Beside the pupils of the Academy of Fine Arts at Munich, I think that every soul who could paint, were it only the smallest sketch, was there to pay homage to the great master. All went in procession to the place where the monument is to be raised, and the magistrates of the city laid the first stones of the pedestal. To my amusement they cemented these first stones with a mortar which was served in great silver platters, and made of fine pounded porcelain mixed with champagne. In the evening all the streets were illuminated; there were balls, concerts, and plays, so that we must have been doubled or quadrupled to see everything. We stayed some days longer at Nüremberg to visit the other curiosities of the city, especially its beautiful churches, its manufactories, etc., and then started on our return to Ratisbon. . . . 


\section{CHAPTER III.}

$1828-1829$ : ET. $21-22$.

First Important Work in Natural History. - Spix's Brazilian Fishes. - Second Vacation Trip. - Sketch of Work during University Year. - Extracts from the Journal of Mr. Dinkel. - Home Letters. - Hope of joining Humboldt's Asiatic Expedition. - Diploma of Philosophy. - Completion of First Part of the Spix Fishes. - Letter concerning it from Cuvier.

IT was not without a definite purpose that Agassiz had written to his father some weeks before, "Should I during the course of my studies succeed in making myself known by a distinguished work, would you not then consent that I should study for one year the natural sciences alone?" Unknown to his parents, for whom he hoped to prepare a delightful surprise, Agassiz had actually been engaged for months on the first work which gave him distinction in the scientific world; namely, a description of the Brazilian fishes brought home by Martius and Spix from their celebrated journey in Brazil. This was the secret to which allusion is made in the next 
letter. To his disappointment an accident brought his undertaking to the knowledge of his father and mother before it was completed. $\mathrm{He}$ always had a boyish regret that his little plot had been betrayed before the moment for the denouement arrived. The book was written in Latin and dedicated to Cuvier. ${ }^{1}$

TO HIS BROTHER.

Munich, July 27, 1828.

...Various things which I have begun keep me a prisoner hère. Probably I shall not stir during the vacation, and shall even give up the little trip in the Tyrol, which I had thought of making as a rest from occupations that bind me very closely at present, but from which I hope to free myself in the course of the holidays. Don't be angry with me for not telling you at once what they are. When you know, I hope to be forgiven for keeping you so long in the dark. I have kept it a secret from papa too, though in his last letter he asks me what is my especial work just now. A few months more of patience, and I will give you a strict account of

1 Selecta genera et species piscium quos collegit et pingendos curavit Dr.J.W. de Spix. Digessit, descripsit et observationibus illustravit Dr. L. Agassiz. 
my time since I came here, and then I am sure you will be satisfied with me. I only wish to guard against one thing : do not take it into your head that I am about to don the fool's cap suddenly and surprise you with a Doctor's degree; that would be going a little too fast, nor do I think of it yet. ... I want to remind you not to let the summer pass without getting me fishes according to the list in my last letter, which I hope you have not mislaid. You would give me great pleasure by sending them as soon as possible. Let me tell you why. M. Cuvier has announced the publication of a complete work on all the known fishes, and in the prospectus he calls on such naturalists as occupy themselves with ichthyology to send him the fishes of the country where they live; he mentions those who have already sent him collections, and promises duplicates from the Paris $\mathrm{Mu}$ seum to those who will send him more. He names the countries also from which he has received contributions, and regrets that he has nothing from Bavaria. Now I possess several specimens of all the native species, and have even discovered some ten not hitherto known to occur here, beside one completely new to science, which I have named Cyprinus 
uranoscopus on account of the position of the eyes, placed on the top instead of the sides of the head, - otherwise very like the gudgeon. I have therefore thought I could not better launch myself in the scientific world than by sending Cuvier my fishes with the observations I have made on their natural history. To these I should like to add such rare Swiss species as you can procure for me. So do not fail.

FROM HIS BROTHER.

Neuchâtel, August 25, 1828.

... I received in good time, and with infinite delight, your pleasant letter of July 27th. Its mysteries have however been unveiled by $\mathrm{Dr}$. Schinz, who came to the meeting of the Natural History Society in Lausanne, where he met papa and my uncle, to whom he pronounced the most solemn eulogiums on their son and nephew, telling them at the same time what was chiefly occupying you now. I congratulate you, my dear brother, but I confess that among us all I am the least surprised, for my presentiments about you outrun all this, and I hope soon to see them realized. In all frankness I can assure you that the stoutest antagonists of your natural history schemes begin to come 
over to your side. Among them is my uncle here, who never speaks of you now but with enthusiasm. What more can be said? I gave him your letter to read, and since then he has asked me a dozen times at least if I had not forgotten to forward the remittance you asked for, saying that I must not delay it. 'The truth is, I have deferred writing till the last moment, because I have not succeeded in getting your fishes, and have always been hoping that I might be able to fulfill your commission. I busied myself on your behalf with all the zeal and industry of which I was capable, but quite in vain. The devil seemed to be in it. The season of Bondelles was over two months ago, and there are none to be seen; as to trout, I don't believe one has been eaten in the whole town for six weeks. I am forever at the heels of the fishermen, promising them double and treble the value of the fish I want, but they all tell me they catch nothing except pike. I have been to Cudrefin for lampreys, but found nothing. Rodolphe ${ }^{1}$ has been paddling in the brook every day without success. I went to Sauge, - no eels, no anything but perch and a few little cat-fish. Two mortal Sundays did I spend, rod in hand, trying to

${ }^{1}$ An experienced old boatman. 
catch bream, chubs, etc. I did get a few, but they were not worth sending. Now it is all over for this year, and we may as well put on mourning for them; but I promise you that as soon as the spring opens I will go to work, and you shall have all you want. If, in spite of everything, your hopes are not realized, I shall be very sorry, but rest assured that it is not my fault. . . .

TO HIS SISTER CECILE.

Munich, October 29, 1828.

... I have never written you about what has engrossed me so deeply; but since my secret is out, I ought not to keep silence longer. That you may understand why I have entered upon such a work I will go back to its origin. In 1817 the King of Bavaria sent two naturalists, M. Martius and M. Spix, on an exploring expedition to Brazil. Of M. Martius, with whom I always spend my Wednesday evenings, I have often spoken to you. In 1821 these gentlemen returned to their country laden with new discoveries, which they published in succession. M. Martius issued colored illustrations of all the unknown plants he had collected on his journey, while, M. Spix brought out several folio volumes 
on the monkeys, birds, and reptiles of Brazil, the animals being drawn and colored, chiefly life-size, by able artists. It had been his intention to give a complete natural history of Brazil, but to the sorrow of all naturalists he died in 1826. M. Martius, desirous to see the completion of the work which his traveling companion had begun, engaged a professor from Erlangen to publish the shells, and these appeared last year. When I came to Munich there remained only the fishes and insects, and M. Martius, who had learned something about me from the professors to whom I was known, found me worthy to continue the work of Spix, and asked me to carry on the natural history of the fishes. I hesitated for a long time to accept this honorable offer, fearing that the occupation might withdraw me too much from my studies; but, on the other hand, the opportunity for laying the foundation of a reputation by a large undertaking seemed too favorable to be refused. The first volume is already finished, and the printing was begun some weeks ago. You can imagine the pleasure I should have had in sending it to our " dear father and mother before they had heard one word about it, or knew even of 
the proposition. But I hope the premature disclosure of my secret (indeed, to tell the truth, I had not imposed silence on M. Schinz, not dreaming that he would see any one of the family) will not diminish your pleasure in receiving the first work of your brother Louis, which I hope to send you at Easter. Already forty colored folio plates are completed. Will it not seem strange when the largest and finest book in papa's library is one written by his Louis? Will it not be as good as to see his prescription at the apothecary's? It is true that this first effort will bring me in but little; nothing at all, in fact, because M. de Martius has assumed all the expenses, and will, of course, receive the profits. My share will be a few copies of the book, and these I shall give to the friends who have the first claim.

To his father Agassiz only writes of his work at this time: "I have been very busy this summer, and I can tell you from a good source (I have it from one of the professors himself) that the professors whose lectures I have attended have mentioned me more than once, as one of the most assiduous and best informed students of the university; saying voL. $\mathrm{I}$. 
also that I deserved distinction. I do not tell you this from ostentation, but only that you may not think I lose my time, even though I occupy myself chiefly with the natural sciences. I hope yet to prove to you that with a brevet of Doctor as a guarantee, Natural History may be a man's bread-winner as well as the delight of his life." . . .

In September Agassiz allowed himself a short interruption of his work. The next letter gives some account of this second vacation trip.

\section{TO HIS PARENTS.}

Munich, September 26, 1828.

. . The instruction for the academic year closed at the end of August, and our professors had hardly completed their lectures when I began my Alpine excursion. Braun, impatient to leave Munich, had already started the preceding day, promising to wait for me on the Salzburg road at the first spot which pleased him enough for a halt. That I might not keep him waiting, I begged a friend to drive me a good day's journey, thinking to overtake Braun the first day on the pleasant banks of the Lake of Chiem. My traveling companions were the younger Schimper [Wil- 
helm], of whom I have spoken to you (and who made a botanical journey in the south of France and the Pyrenees two years ago), and Mahir, who drove us, with whom I am very intimate; he is a medical student, and also a very enthusiastic physicist. He gave me private lessons in mathematics all winter, and was a member of our philomathic meetings. Braun had not set out alone either, and his two traveling companions were also friends of ours. One was Trettenbacher, a medical student greatly given to sophisms and logic, but allowing himself to be beaten in argument with the utmost good nature, though always believing himself in the right; a thoroughly good fellow with all that, and a great connoisseur of antiquities. The other was a young student, Moré, from the ci-devant department of Mt. Tonnerre, who devotes himself entirely to the natural sciences, and has chosen the career of traveling naturalist. You can easily imagine that this attracts me to him, but as he is only a beginner I am, as it were, his mentor.

On the morning of our departure the weather was magnificent. Driving briskly along we had various surmises as to where we should probably meet our traveling com- 
panions, not doubting that, as we hoped to reach the Lake of Chiem the same day, we should come across them the day following on one of its pretty islands. But in the afternoon the weather changed, and we were forced to seek shelter from torrents of rain at Rosenheim, a charming town on the banks of the Inn, where I saw for the first time this river of Helvetic origin. I saluted it as a countryman of mine, and wished I could change its course and send it back laden with my greetings. The next day Mahir drove us as far as the shore of the lake. There we parted from him, and took a boat to the islands, where we were much disappointed not to find Braun and his companions. We thought the bad weather of the day before (for here it had rained all day) might have obliged them to malse the circuit of the lake. However, in order to overtake them before reaching Salzburg, we kept our boatmen, and were rowed across to the opposite shore near Grabenstadt, where we arrived at ten o'clock in the evening. In the afternoon the weather had cleared a little, and the view was beautiful as we pulled away from the islands and watched them fade in the twilight. I also gathered much interesting information about the in. 
habitants of the waters of this lake. Among others, I was much pleased to find a cat-fish, taken in the lake by one of the island fishermen, and also a kind of chub, not found in Switzerland, and called by the fishermen here "Our Lady's Fish," because it occurs only on the shore of an island where there is a convent, the nuns of which esteem it a great delicacy.

The third day we reached Traunstein, where, although it was Sunday, there was a great horse fair. We looked with interest at the gay Tyroleans, with the cock-feathers in their pointed hats, singing and jödeling in the streets with their sweethearts on their arms. Every now and then they let fall some sarcastic comment on our accoutrements, which were indeed laughable enough to these people, who had never seen anything beyond their own chalets, and for whom an excursion from their mountains to a fair in the nearest town is a journey. It was noon when we stopped at Traunstein, and from there to Salzburg is but five leagues. Before reaching the fortress, however, you must pass the great custom-house on the Bavarian frontier, and fearing we might be delayed there too long by the stupid Austrian officials, and thus be pre- 
vented from entering the city before the gates were closed, we resolved to wait till the next morning and spend the night at Adelstaetten, a pretty village about a league from Salzburg, and the last Bavarian post. Night was falling as we approached a little wood which hid the village from us. There we asked a peasant how far we had still to go, and when he had answered our question he told us, evidently with kind intention, that we should find good company in the village, for a few hours earlier three journeymen laborers had arrived there; and then he added that we should no doubt be glad to meet comrades and have a gay evening with them. We were not astonished to be taken for workmen, since every one who travels here on foot, with a knapsack on his back, is understood to belong to the laboring class. . . . Arrived at the village, we were delighted to find that the three journeymen were our traveling companions. They had come, like ourselves, from Traunstein, where we had missed each other in the crowd, and they were going likewise to sleep at Adelstaetten, to avoid the custom-house. Finally, on Monday, at ten o'clock, we crossed the long bridge over the Saala, between the white coats with yellow trimmings on guard there. 
On the Bavarian frontier we had hardly remembered that there was a custom-house, and the name of student sufficed to pass us without our showing any passports; here, on the contrary, it was another reason for the strictest examination. "Have you no forbidden books?" was the first question. By good fortune, before crossing the bridge, I had advised Trettenbach to hide his song-book in the lining of his boot. I am assured that had it been taken upon him he would not have been allowed to pass. In ransacking Braun's bag, one of the officials found a shell such as are gathered by the basketful on the shores of the Lake of Neuchâtel. His first impulse was to go to the office and inquire whether we should not pay duty on this, saying that it was no doubt for the fabrication of false pearls, and we probably had plenty more. We had all the difficulty in the world to make him understand that not fifty steps from the custom-house the shores of the river were strewn with them. . . After all this we had to empty our purses to show that we had money enough for our journey, and that we should not be forced to beg in order to get through. While we underwent this inquisition, another officer made a tour of inspection around us, to observe our general 
bearing, etc. ... After having kept us thus on coals for two hours they gave us back our passports, and we went our way. At one o'clock we arrived at Salzburg as hungry as wolves, but at the gate we had still to wait and give up our passports again in exchange for receipts, in virtue of which we could obtain permits from the police to remain in the city. From our inn, we sent a waiter to get these permits, but he presently returned with the news that we must go in person to take them; there was, however, no hurry; it would do in three or four hours! We had no farther difficulty except that it was made a condition of our stay that we should not appear in student's dress. This dress, they said, was forbidden in Austria. They begged Moré to have his hair cut, otherwise it would be shortened gratis, and also informed us that at our age it was not becoming to dispense with cravats. Happily, I had two with me, and Braun tied his handkerchief around his neck. It astonished me, also, to see that we were not entered on the list of strangers published every evening. So it was also, as we found, with other students, though the persons who came with them by the same conveyance, even the children, were duly inscribed. It seems this is a precaution against any gathering of strdents. . . . 
The letter concludes in haste for the mail, and if the story of the journey was finished the final chapter has not been preserved. Some extracts from the home letters of Agassiz's friend Braun, which are in place here, throw light on their university life for the coming year. ${ }^{1}$

ALEXANDER BRAUN TO HIS FATHER.

MUNICH, November 18, 1828.

.. I will tell you how we have laid out our time for this term. Our human consciousness may be said to begin at half-past five o'clock in the morning. The hour from six to seven is appointed for mathematics, namely, geometry and trigonometry. To this appointment we are faithful, unless the professor oversleeps himself, or Agassiz happens to have grown to his bed, an event which sometimes occurs at the opening of the term. From seven to eight we do as we like, including breakfast. Under Agassiz's new style of housekeeping the coffee is made in a machine which is devoted during the day to the soaking of all sorts of creatures for skeletons, and in the evening again to the brewing of our

1 See Life of Alexander Braun, by his daughter, Madame Cecile Mettenius. 
tea. At eight o'clock comes the clinical lecture of Ringseis. As Ringseis is introducing an entirely new medical system, this is not wholly without general physiological and philosophical interest. At ten o'clock Stahl lectures, five times a week, on mechanics as preliminary to physics. These and also the succeeding lectures, given only twice a week on the special natural history of amphibians by Wagler, we all attend together. From twelve to one o'clock we have nothing settled as yet, but we mean to take the lectures of Döllinger, in single chapters, as, for instance, when he comes to the organs of the senses. At one o'clock we go to dinner, for which we have at last found a comfortable and regular place, at a private house, after having dined everywhere and anywhere, at prices from nine to twenty kreutzers. Here, for thirteen kreutzers ${ }^{1}$ each, in company with a few others, mostly known to us, we are provided with a good and neatly served meal. After dinner we go to Dr. Waltl, with whom we study chemistry, using Gmelin's text-book, and are shown the most important experiments. Next week we are to begin entomology with Dr. Perty, from three to four, three times a week.

1 About nine cents of our money. 
From one to two o'clock on Saturday we have a lesson in experimental physiology, plainly speaking, in animal dissection, from Dr. Oesterreicher, a young Docent, who has written on the circulation of the blood. As Agassiz dissects a great many animals, especially fishes, at the house, we are making rapid progress in comparative anatomy. At four o"clock we go usually once a week to hear Oken on " $\mathrm{Na}$ tur-philosophie" (a course we attended last term also), but by that means we secure a good seat for Schelling's lecture immediately after. A man can hardly hear twice in his life a course of lectures so powerful as those Schelling is now giving on the philosophy of revelation. This will sound strangely to you, because, till now, men have not believed that revelation could be a subject for philosophical treatment; to some it has seemed too sacred; to others too irrational. . . This lecture brings us to six o'clock, when the public courses are at an end: we go home, and now begin the private lectures. Sometimes Agassiz tries to beat French rules and constructions into our brains, or we have a lesson in anatomy, or I read general natural history aloud to William Schimper. By and by I shall review the natural history of grasses 
and ferns, two families of which I made a special study last summer. Twice a week Karl Schimper lectures to us on the morphology of plants; a very interesting course on a subject but little known. He has twelve listeners. Agassiz is also to give us lectures occasionally on Sundays upon the natural history of fishes. You see there is enough to do....

Somewhat before this, early in 1828, Agassiz had made the acquaintance of Mr. Joseph Dinkel, an artist. A day spent together in the country, in order that $\mathrm{Mr}$. Dinkel might draw a brilliantly colored trout from life, under the immediate direction of the young naturalist, led to a relation which continued uninterruptedly for many years. Mr. Dinkel afterward accompanied Agassiz, as his artist, on repeated journeys, being constantly employed in making illustrations for the "Poissons Fossiles" and the "Poissons d'Eau Douce," as well as for his monographs and smaller papers. The two larger works, the latter of which remained unfinished, were even now in embryo. Not only was Mr. Dinkel at work upon the plates for the Fresh-Water Fishes, but Mr. J. C. Weber, who was then 
engaged in making, under Agassiz's direction, the illustrations for the Spix Fishes, was also giving his spare hours to the same objects. Mr. Dinkel says of Agassiz's student life at this time $:^{1}$

"I soon found myself engaged four or five hours almost daily in painting for him freshwater fishes from the life, while he was at my side, sometimes writing out his descriptions, sometimes directing me. . . He never lost his temper, though often under great trial; he remained self-possessed and did everything calmly, having a friendly smile for every one and a helping hand for those who were in need. He was at that time scarcely twenty years old, and was already the most prominent among the students at Munich. They loved him, and had a high consideration for him. I had seen him at the Swiss students' club several times, and had observed him among the jolly students; he liked merry society, but he himself was in general reserved and never noisy. He picked out the gifted and highlylearned students, and would not waste his time

1 Extract from notes written out in Engiish by Mr. Dinkel after the death of Agassiz and sent to me. The English, though a little foreign, is so expressive that it would lose by any attempt to change it, and the writer will excuse me for inserting his vivid sketch just as it stands. - E. C. A. 
in ordinary conversation. Often, when he saw a number of students going off on some empty pleasure-trip, he said to me, "There they go with the other fellows; their motto is, "Ich gehe mit den andern." I will go my own way, Mr. Dinkel, - and not alone: I will be a leader of others.' In all his doings there was an ease and calm which was remarkable. His studio was a perfect German student's room. It was large, with several wide windows; the furniture consisted of a couch and about half a dozen chairs, beside some tables for the use of his artists and himself. Dr. Alex. Braun and Dr. Schimper lodged in the same house, and seemed to me to share his studio. Being botanists, they, too, brought home what they collected in their excursions, and all this found a place in the atelier, on the couch, on the seats, on the floors. Books filled the chairs, one alone being left for the other artist, while I occupied a standing desk with my drawing. No visitor could sit down, and sometimes there was little room to stand or move about. The walls were white, and diagrams were drawn on them, to which, by and by, we artists added skeletons and caricatures. In short, it was quite original. I was some time there before I could discover 
the real names of his friends: each had a nickname, - Molluscus, Cyprinus, Rhubarb, etc."

From this glimpse into "The Little Academy" we return to the thread of the home letters, learning from the next one that Agassiz's private collections were assuming rather formidable proportions when considered as part of the household furniture. Brought together in various ways, partly by himself, partly in exchange for duplicates, partly as pay for arranging specimens in the Munich Museum, they had already acquired, when compared with his small means, a considerable pecuniary value, and a far higher scientific importance. They included fishes, some rare mammalia, reptiles, shells, birds, an herbarium of some three thousand species of plants collected by himself, and a small cabinet of minerals. After enumerating them in a letter to his parents he continues: "You can imagine that all these things are in my way now that I cannot attend to them, and that for want of room and care they are piled up and in danger of spoiling. You see by my list that the whole collection is valued at two hundred louis; and this is so low an estimate that even those who sell objects of natural his- 
tory would not hesitate to take them at that price. You will therefore easily understand how anxious $I$ am to keep them intact. Can you not find me a place where they might be spread out? I have thought that perhaps my uncle in Neuchâtel would have the kindness to let some large shelves be put up in the little upper room of his house in Cudrefin, where, far from being an annoyance or causing any smell, my collection, if placed in a case under glass, or disposed in some other suitable manner, would be an ornament. Be so kind as to propose it to him, and if he consents I will then tell you what I shall need for its arrangement. Remember that on this depends, in great part, the preservation of my specimens, and answer as soon as possible."

Agassiz was now hurrying forward both his preparation for his degree and the completion of his Brazilian Fishes, in the hope of at last fulfilling his longing for a journey of exploration. This hope is revealed in his next home letter. The letter is a long one, and the first half is omitted since it concerns only the arrangements for his collections, the care to be taken of them, etc. 
TO HIS FATHER.

Munich, February 14, 1829.

-. But now I must talk to you of more important things, not of what I possess, but of what I am to be. Let me first recall one or two points touched upon before in our correspondence, which should now be fully discussed.

1st. You remember that when I first left Switzerland I promised you to win the title of Doctor in two years, and to be prepared (after having completed my studies in Paris) to pass my examination before the "Conseil de Santé," and begin practice.

2d. You will not have forgotten either that you exacted this only that I might have a profession, and that you promised, should I be able to make my way in the career of letters and natural history, you would not oppose my wishes. I am indeed aware that in the latter case you see but one obstacle, that of absence from my country and separation from all who are dear to me. But you know me too well to think that I would voluntarily impose upon myself such an exile. Let us see whether we cannot resolve these difficulties to our mutual satisfaction, and consider what is 
the surest road to the end I have proposed to myself ever since I began my medical studies. Weigh all my reasons, for in this my peace of mind and my future happiness are concerned. Examine my conduct with reference to what I propose in every light, that of son and Vaudois citizen included, and I feel sure you will concur in my views.

Here is my aim and the means by which I propose to carry it out. I wish it may be said of Louis Agassiz that he was the first naturalist of his time, a good citizen, and a good son, beloved of those who knew him. I feel within myself the strength of a whole generation to work toward this end, and I will reach it if the means are not wanting. Let us see in what these means consist. [Here follows the summing up of his reasons for preferring a professorship of natural history to the practice of medicine, and his intention of trying for a diploma as Doctor of Philosophy in Germany.] But how obtain a professorship, you will say, - that is the important point? I answer, the first step is to make myself a European name, and for that I am on the right road. In the first place my work on the fishes of Brazil, just about to appear, will make me favorably known. I 
am sure it will be kindly received; for at the General Assembly of German naturalists and medical men last September, in Berlin, the part already finished and presented before the Assembly was praised in a manner for which I was quite unprepared. The professors also, to whom I was known, spoke of me there in very favorable terms.

In the second place there are now preparing two expeditions of natural history, one by $M$. de Humboldt, with whose reputation you are surely familiar, - the same who spent several years in exploring the equatorial regions of South America, in company with $\mathbf{M}$. Bonpland. He has been for some years at Berlin, and is now about to start on a journey to the Ural Mountains, the Caucasus, and the confines of the Caspian Sea. Braun, Schimper, and I have been proposed to him as traveling companions by several of our professors; but the application may come too late, for M. de Humboldt decided upon this journey long ago, and has probably already chosen the naturalists who are to accompany him. How happy I should be to join this expedition to a country the climate of which is by no means unhealthy, under the direction of a man so generally esteemed, to whom the Em- 
peror of Russia has promised help and an escort at all times and under all circumstances. The second expedition is to a country quite as salubrious, and which presents no dangers whatever for travelers, - South America. It will be under the direction of M. Ackermann, known as a distinguished agriculturist and as Councillor of State to the Grand Duke of Baden. I should prefer to go with Humboldt; but if I am too late, I feel very sure of being able to join the second expedition. So it depends, you see, only on your consent. This journey is to last two years, at the end of which time, happily at home once more, I can follow with all desirable facilities the career $\mathbf{I}$ have chosen. If there should be a place for me at Lausanne, which I should prefer to any other locality, I could devote my life to teaching my young countrymen, awaken in them the taste for science and observation so much neglected among us, and thus be more useful to my canton than I could be as a practitioner. These projects may not succeed; but in the present state of things all the probabilities are favorable. Therefore, I beg you to consider it seriously, to consult my uncle in Lausanne, and to write me at once what you think. ...

In spite of the earnest desire for travel 
shown in this letter it will be seen later how the restless aspirations of childhood, boyhood, and youth, which were, after all, only a latent love of research, crystallize into the concentrated purpose of the man who could remain for months shut up in his study, leaving his microscope only to eat and sleep, - a life as sedentary as ever was lived by a closet student.

FROM HIS FATHER.

Orbe, Fehruary 23, 1829.

. . It was not without deep emotion that we read your letter of the 14th, and I easily understand that, anticipating its effect upon us all, you have deferred writing as long as possible. Yet you were wrong in so doing; had we known your projects earlier we might have forestalled for you the choice of M. de Humboldt, whose expedition seems to us preferable, in every respect, to that of M. Ackermann. The first embraces a wider field, and concerns the history of man rather than that of animals; the latter is confined to an excursion along the sea-board, where there would be, no doubt, a rich harvest for science, but much less for philosophy. However that may be, your father and mother, while they grieve for the day that will separate them from their 
oldest son, will offer no obstacles to his projects, but pray God to bless them. ...

The subjoined letter of about the same date from Alexander Braun to his father tells us how the projects so ardently urged upon his parents by Agassiz, and so affectionately accepted by them, first took form in the minds of the friends.

BRAUN TO HIS FATHER.

Munich, February 15, 1829.

... Last Thursday we were at Oken's. There was interesting talk on all sorts of subjects, bringing us gradually to the Ural and then to Humboldt's journey, and finally Oken asked if we would not like to go with Humboldt. To this we gave warm assent, and told him that if he could bring it about we would be ready to start at a day's notice, and Agassiz added, eagerly, "Yes, - and if there were any hope that he would take us, a word from you would have more weight than anything." Oken's answer gave us but cold comfort; nevertheless, he promised to write at once to Humboldt in our behalf. With this, we went home in great glee; it was very late and a bright moonlight night. Agassiz rolled 
himself in the snow for joy, and we agreed that however little hope there might be of our joining the expedition, still the fact that Humboldt would hear of us in this way was worth something, even if it were only that we might be able to say to him one of these days, "We are the fellows whose company you rejected."

With this hope the friends were obliged to content themselves, for after a few weeks of alternate encouragement and despondency their bright vision faded. Oken fulfilled his promise and wrote to Humboldt, recommending them most warmly. Humboldt answered that his plans were conclusively settled, and that he had chosen the only assistants who were to accompany him, - Ehrenberg and Rose.

In connection with this frustrated plan is here given the rough draft of a letter from Agassiz to Cuvier, written evidently at a somewhat earlier date. Although a mere fragment, it is the outpouring of the same passionate desire for a purely scientific life, and shows that the opportunity suggested by Humboldt's journey had only given a definite aim to projects already full grown. From the contents it must have been written in 1828. After 
some account of his early studies, which would be mere repetition here, he goes on: "Before finishing my letter, allow me to ask some advice from you, whom I revere as a father, and whose works have been till now my only guide. Five years ago I was sent to the medical school at Zurich. After the first few lectures there in anatomy and zoölogy I could think of nothing but skeletons. In a short time I had learned to dissect, and had made for myself a small collection of skulls of animals from different classes. I passed two years in Zurich, studying whatever I could find in the Museum, and dissecting all the animals I could procure. I even sent to Berlin at this time for a monkey in spirits of wine, that I might compare the nervous system with that of man. I spent all the little means I had in order to see and learn as much as possible. Then I persuaded my father to let me go to Heidelberg, where for a year I followed Tiedemann's courses in human anatomy. I passed almost the whole winter in the anatomical laboratory. The following summer I attended the lectures of Leuckart on zoölogy, and those of Bronn on fossils. When at Zurich, the longing to travel some day as a naturalist had taken possession of me, and at Heidelberg this desire 
only increased. My frequent visits to the $\mathrm{Mu}$ seum at Frankfort, and what I heard there concerning M. Riuppell himself, strengthened my purpose even more than all I had previously read. I was, as it were, Ruippell's traveling companion: the activity, the difficulties to be overcome, all were present to me as I looked upon the treasures he had brought together from the deserts of Africa. The vision of difficulty thus vanquished, and of the inward satisfaction arising from it, tended to give all my studies a direction in keeping with my projects.

"I felt that to reach my aim more surely it was important to complete my medical studies, and for this I came to Munich eighteen months ago. Still I could not make up my mind to renounce the natural sciences. I attended some of the pathological lectures, but I soon found that I was neglecting them; and yielding once more to my inclination, I followed consecutively the lectures of Döllinger on comparative anatomy, those of Oken on natural history, those of Fuchs on mineralogy, as well as the courses of astronomy, physics, chemistry, and mathematics. I was confirmed in this withdrawal from medical studies by the proposition of M. de Martius 
that I should describe the fishes brought back by Spix from Brazil, and to this I consented the more gladly because ichthyology has always been a favorite study with me. I have not, however, been able to give them all the care I could have wished, for M. de Martius, anxious to complete the publication of these works, has urged upon me a rapid execution. I hope, nevertheless, that I have made no gross errors, and I am the less likely to have done so, because I had as my guide the observations you had kindly made for him on the plates of Spix. Several of these plates were not very exact; they have been set aside and new drawings made. I beg that you will judge this work when it reaches you with indulgence, as the first literary essay of a young man. I hope to complete it in the course of the next summer. I would beg you, in advance, to give me a paternal word of advice as to the direction my studies should then take. Ought I to devote myself to the study of medicine? I have no fortune, it is true; but I would gladly sacrifice my life if, by so doing, I could serve the cause of science. Though I have not even a presentiment of any means with which I may one day travel in distant countries, I have, nevertheless, prepared 
myself during the last three years as if I might be off at any minute. I have learned to skin all sorts of animals, even very large ones. I have made more than a hundred skeletons of quadrupeds, birds, reptiles, and fishes; I have tested all the various liquors for preserving such animals as should not be skinned, and have thought of the means of supplying the want in countries where the like preparations are not to be had, in case of need. Finally, I have trained as traveling companion a young friend, ${ }^{1}$ and awakened in him the same love of the natural sciences. He is an excellent hunter, and at my instigation has been taking lessons in drawing, so that he is now able to sketch from nature such objects as may be desirable. We often pass delightful moments in our imaginary travels through unknown countries, building thus our castles in Spain. Pardon me if I talk to you of projects which at first sight seem puerile; only a fixed aim is needed to give them reality, and to you I come for counsel. My longing is so great that I feel the need of expressing it to some one who will understand me, and your sympathy would make me the happiest of mortals. I am so pursued by this thought of a scientific I William Schimper, brother of Karl. 
journey that it presents itself under a thousand forms, and all that I undertake looks toward one end. I have for six months frequented a blacksmith's and carpenter's shop, learning to handle hammer and axe, and I also practice arms, the bayonet and sabre exercise. I am strong and robust, know how to swim, and do not fear forced marches. I have, when botanizing and geologizing, walked my twelve or fifteen leagues a day for eight days in succession, carrying on my back a heavy bag loaded with plants or minerals. In one word, I seem to myself made to be a traveling naturalist. I only need to regulate the impetuosity which carries me away. I beg you, then, to be my guide."

The unfinished letter closes abruptly, having neither signature nor address. Perhaps the writer's courage failed him and it never was sent. An old letter (date 1827) from Cuvier to Martius, found among Agassiz's papers of this time, and containing the very notes on the Spix Fishes to which allusion is here made, leaves no doubt, however, that this appeal was intended for the great master who exercised so powerful an influence upon Agassiz throughout his whole life.

In the spring of 1829 Agassiz took his 
diploma in the faculty of philosophy. He did this with no idea of making it a substitute for his medical degree, but partly in deference to Martius, who wished the name of his young colleague to appear on the title-page of the Brazilian Fishes with the dignity of Doctor, and partly because he believed it would strengthen his chance of a future professorship. Of his experience on this occasion he gives some account in the following letter :-

TO HIS BROTHER.

Munich, May 22, 1829.

- As it was necessary for me to go through with my examination at once, and as the days for promotion here were already engaged two months in advance, I decided to pass it at Erlangen. That I might not go alone, and also for the pleasure of their company, I persuaded Schimper and Michahelles to do the same. Braun wanted to be of the party, but afterward decided to wait awhile. We made our request to the Faculty in a long Latin letter (because, you know, among savants it is the thing to speak and write the language you know least), requesting permission to pass our examination in writing, and to go to Erlangen only for the colloquium and 
promotion. They granted our request on condition of our promise (jurisjurandi loco polliciti sumus) to answer the questions propounded without help from any one and without consulting books. Among other things I had to develop a natural system of zoölogy, to show the relation between human history and natural history, to determine the true basis and limits of the philosophy of nature, etc. As an inaugural dissertation, I presented some general and novel considerations on the formation of the skeleton throughout the animal kingdom, from the infusoria, mollusks, and insects to the vertebrates, properly so called. The examiners were sufficiently satisfied with my answers to give me my degree the $23 \mathrm{~d}$ or 24th of April, without waiting for the colloquium and promotion, writing to me that they were satisfied with my examination, and therefore forwarded my diploma without regard to the oral examination. . . . The Dean of the Faculty, in inclosing it to me, added that he hoped before long to see me professor, and no less the ornament of my university in that position than I had hitherto been as student. I must try not to disappoint him.... 
A letter from his brother contains a few lines in reference to this. "Last evening, dear Louis, your two diplomas reached me. I congratulate you with all my heart on your success. I am going to send to grandpapa the one destined for him, and I see in advance all his pleasure, though it would be greater if the word medicine stood for that of philosophy."

The first part of the work on the Brazilian Fishes was now completed, and he had the pleasure of sending it to his parents as his own forerunner. After joining a scientific meeting to be held at Heidelberg, in September, he was to pass a month at home before returning to Munich for the completion of his medical studies.

TO HIS PARENTS.

Munich, July 4, 1829.

... I hope when you read this letter you will have received the first part of my Brazilian Fishes from M. whom Martius had to send a package of plants, with which my book was inclosed. I venture to think that this work will give me a name, and I await with impatience the criticism that $\mathrm{I}$ suppose it will receive from $\mathrm{Cu}$ - 
vier. . . I think the best way of reaching the various aims $I$ have in view is to continue the career on which I have started, and to publish as soon as possible my natural history of the fresh-water fishes of Germany and Switzerland. I propose to issue it in numbers, each containing twelve colored plates accompanied by six sheets of letter-press. . . . In the middle of September there is to be a meeting of all the naturalists and medical men of Germany, to which foreign savants are invited. A similar meeting has been held for the last two or three years in one or another of the brilliant centres of Germany. This year it will take place at Heidelberg. Could one desire a better occasion to make known a projected work? I could even show the original drawings already made of species only found in the environs of Munich, and, so to speak, unknown to naturalists. At Heidelberg will be assembled Englishmen, Danes, Swedes, Russians, and even Italians. If I could before then arrange everything and distribute the printed circulars of my work I should be sure of success. ...

In those days of costly postage one sheet of writing paper was sometimes made to serve for several members of the family. The next 
crowded letter contains chiefly domestic details, but closes with a postscript from Mme. Agassiz, filling, as she says, the only remaining corner, and expressing her delight in his diploma and in the completion of his book.

FROM HIS MOTHER.

August 16, 1829.

.. The place your brother has left me seems very insufficient for all that $I$ have to say, dear Louis, but I will begin by thanking you for the happiness, as sweet as it is deeply felt, which your success has given us. Already our satisfaction becomes the reward of your efforts. We wait with impatience for the moment when we shall see you and talk with you. Your correspondence leaves many blanks, and we are sometimes quite ashamed that we have so few details to give about your book. You will be surprised that it has not yet reached us. Does the gentleman in Geneva intend to read it before sending it to us, or has he perhaps not received the package? Not hearing we are uneasy.... Good-by, my dear son; I have no room for more, except to add my tender love for you. An honorable mention of your name in the Lausanne Gazette has brought us many pleasant congratulations. ... VOL. I. 
. . I I hope by this time you have my book. I can the less explain the delay since M. Cuvier, to whom I sent it in the same way, has acknowledged its arrival. I inclose his letter, hoping it will give you pleasure to read what one of the greatest naturalists of the age writes me about it.

CUVIER TO LOUIS AGASSIZ.

Paris, aU Jardin du RoI, August 3, 1829.

... You and M. de Martius have done me honor in placing my name at the head of a work so admirable as the one you have just published. The importance and the rarity of the species therein described, as well as the beauty of the figures, will make the work an important one in ichthyology, and nothing could heighten its value more than the accuracy of your descriptions. It will be of the greatest use to me in my History of Fishes. I had already referred to the plates in the second edition of my "Régne Animal." I shall do all in my power to accelerate the sale among amateurs, either by showing it to such as meet at my house or by calling attention to it in scientific journals. 
I look with great interest for your history of the fishes of the Alps. It cannot but fill a wide gap in that portion of natural history, - above all, in the different divisions of the genus Salmo. The figures of Bloch, those of Meidinger, and those of Marsigli, are quite insufficient. We have the greater part of the species here, so that it will be easy for me to verify the characters; but only an artist, working on the spot, with specimens fresh from the water, can secure the colors. You will, no doubt, have much to add also respecting the development, habits, and use of all these fishes. Perhaps you would do well to limit yourself at first to a monograph of the Salmones.

With my thanks for the promised documents, accept the assurance of my warm regard and very sincere attachment.

B. G. Cuvier.

At last comes the moment, so long anticipated, when the young naturalist's first book is in the hands of his parents. The news of its reception is given in a short and hurried note. 


\section{FROM HIS FATHER.}

Orbe, August 31, 1829.

I hasten, my dear son, to announce the arrival of your beautiful work, which reached us on Thursday, from Geneva. I have no terms in which to express the pleasure it has given me. In two words, for I have only a moment to myself, I repeat my urgent entreaty that you would hasten your return as much as possible. .. The old father, who waits for you with open heart and arms, sends you the most tender greeting. ... 


\section{CHAPTER IV.}

$1829-1830$ : ÆT. $22-23$.

Scientific Meeting at Heidelberg. - Visit at Home. - Illness and Death of his Grandfather. - Return to Munich.Plans for Future Scientific Publications. - Takes his Degree of Medicine. - Visit to Vienna. - Return to Munich. - Home Letters. - Last Days at Munich. - Autobiographical Review of School and University Life.

\section{TO HIS PARENTS.}

Heidelberg, September 25, 1829.

... The time of our meeting is almost at hand. Relieved from all anxiety about the subjects I had wished to present here, I can now be quietly with you and enjoy the rest and freedom I have so long needed. The tension of mind, forced upon me by the effort to reach my goal in time, has crowded out the thoughts which are most present when I am at peace. I will not talk to you of what I have been doing lately, (a short letter from Frankfort will have put you on my track), nor of the relations I have formed at the Heidelberg meeting, nor of the manner in which 
I have been received, etc. These are matters better told than written. ... I intend to leave here to-morrow or the day after, according to circumstances. I shall stay some days at Carlsruhe to put my affairs in order, and from there make the journey home as quickly as possible...

The following month we find him once more at home in the parsonage of Orbe. After the first pleasure and excitement of return, his time was chiefly spent in arranging his collections at Cudrefin, where his grandfather had given him house-room for them. In this work he had the help of the family in general, who made a sort of scientific fête of the occasion. But it ended sadly with the illness and death of the kind old grandfather, under whose roof children and grandchildren had been wont to assemble.

\section{AGASSIZ TO BRAUN.}

OrBe, December 3, 1829.

. . I I will devote an hour of this last evening I am to pass in Orbe, to talking with you. You will wonder that I am still here, and that I have not written. You already know that I have been arranging my collections at Cudre- 
fin, and spending very happy days with my grandfather. But he is now very ill, and even should we have better news of him to-day, the thought weighs heavily on my heart, that I must take leave of him when he is perhaps on his death-bed.... I have just tied up my last package of plants, and there lies my whole herbarium in order, - thirty packages in all. For this I have to thank you, dear Alex., and it gives me pleasure to tell you so and to be reminded of it. What a succession of glorious memories came up to me as I turned them over. Free from all disturbing incidents, I enjoyed anew our life together, and even more, if possible, than in actual experience. Every talk, every walk, was present to me again, and in reviewing it all I saw how our minds had been drawn to each other in an ever-strengthening union. In you I see my own intellectual development reflected as in a mirror, for to you, and to my intercourse with you, I owe my entrance upon this path of the noblest and most lasting enjoyment. It is delightful to look back on such a past with the future so bright before us. ...

Agassiz now returned to Munich to add the title of Doctor of Medicine to that of Doctor 
of Philosophy. A case of somnambulism, which fell under his observation and showed him disease, or, at least, abnormal action of the brain, under an aspect which was new to him, seems to have given a fresh impulse to his medical studies, and, for a time, he was inclined to believe that the vocation which had thus far been to him one of necessity, might become one of preference. But the naturalist was stronger than the physician. During this very winter, when he was preparing himself with new earnestness for his profession, a collection of fossil fishes was put into his hands by the Director of the Museum of Munich. It will be seen with what ardor he threw himself into this new investigation. His work on the "Poissons Fossiles," which placed him in a few years in the front rank of European scientific men, took form at once in his fertile brain.

TO HIS BROTHER.

Munich, January 18, 1830.

... My resolve to study medicine is now confirmed. I feel all that may be done to render this study worthy the name of science, which it has so long usurped. Its intimate alliance with the natural sciences and the enlightenment it promises me regarding them 
are indeed my chief incitements to persevere in my resolution. In order to gain time, and to strike while the iron is hot (don't be afraid it will grow cold; the wood which feeds the fire is good), I have proposed to Euler, with whom I am very intimate, to review the medical course with me. Since then, we pass all our evenings together, and rarely separate before midnight, — reading alternately French and German medical books. In this way, although I devote my whole day to my own work about fishes, I hope to finish my professional studies before summer. I shall then pass my examination for the Doctorate in Germany, and afterward do the same in Lausanne. I hope that this decision will please mama. My character and conduct are the pledge of its accomplishment.

This, then, is my night-work. I have still to tell you what I do by day, and this is more important. My first duty is to complete my Brazilian Fishes. To be sure, it is only an honorary work, but it must be finished, and is an additional means of making subsequent works profitable. This is my morning occupation, and I am sure of bringing it to a close about Easter. After much reflection, I have decided that the best way to turn my Fresh- 
Water Fishes to account, is to finish them completely before offering them to a publisher. All the expenses being then paid, I could afford, if the first publisher should not feel able to take them on my own terms, to keep them as a safe investment. The publisher himself seeing the material finished, and being sure of bringing it out as a complete work, the value of which he can on that account better estimate, will be more disposed to accept my proposals, while I, on my side, can be more exacting. The text for this I write in the afternoon. My greatest difficulty at first was the execution of the plates. But here, also, my good star has served me wonderfully. I told you that beside the complete drawings of the fishes I wanted to represent their skeletons and the anatomy of the soft parts, which has never been done for this class. I shall thereby give a new value to the work, and make it desirable for all who study comparative anatomy. The puzzle was to find some one who was prepared to draw things of this kind; but I have made the luckiest hit, and am more than satisfied. My former artist continues to draw the fishes, a second draws the skeletons (one who had already been engaged for several years in the same way, for a work 
upon reptiles), while a young physician, who is an admirable draughtsman, makes my anatomical figures. For my share, I direct their work while writing the text, and thus the whole advances with great strides. I do not, however, stop here. Having by permission of the Director of the Museum one of the finest collections of fossils in Germany at my disposition, and being also allowed to take the specimens home as I need them, I have undertaken to publish the ichthyological part of the collection. Since it only makes the difference of one or two people more to direct, I have these specimens also drawn at the same time. Nowhere so well as here, where the Academy of Fine Arts brings together so many draughtsmen, could I have the same facility for completing a similar work; and as it is an entirely new branch, in which no one has as yet done anything of importance, I feel sure of success; the more so because Cuvier, who alone could do it (for the simple reason that every one else has till now neglected the fishes), is not engaged upon it. Add to this that just now there is a real need of this work for the determination of the different geological formations. Once before, at the Heidelberg meeting, it had been proposed to me; the 
Director of the Mines at Strasbourg, M. Voltz, even offered to send me at Munich the whole collection of fossil fishes from their Museum. I did not speak to you of this at the time because it would have been of no use. But now that I have it in my power to carry out the project, I should be a fool to let a chance escape me which certainly will not present itself a second time so favorably. It is therefore my intention to prepare a general work on fossil ichthyology. I hope, if I can command another hundred louis, to complete everything of which I have spoken before the end of the summer, that is to say, in July. I shall then have on hand two works which should surely be worth a thousand louis to me. This is a low estimate, for even ephemeral pieces and literary ventures are paid at this price. You can easily malse the calculation. They allow three louis for each plate with the accompanying text; my fossils will have about two hundred plates, and my fresh-water fishes about one hundred and fifty. This seems to me plausible. ...

This letter evidently made a favorable impression on the business heads of the family at Neuchâtel, for it is forwarded to his par- 
ents, with these words from his brother on the last sheet: "I hasten, dear father, to send you this excellent letter from my brother, which has just reached me. They have read it here with interest, and Uncle François Mayor, especially, sees both stability and a sound basis in his projects and enterprises."

There is something touching and almost amusing in Agassiz's efforts to give a prudential aspect to his large scientific schemes. He was perfectly sincere in this, but to the end of his life he skirted the edge of the precipice, daring all, and finding in himself the power to justify his risks by his successes. $\mathrm{He}$ was of frugal personal habits; at this very time, when he was keeping two or three artists on his slender means, he made his own breakfast in his room, and dined for a few cents a day at the cheapest eating houses. But where science was concerned the only economy he recognized, either in youth or old age, was that of an expenditure as bold as it was carefully considered.

In the above letter to his brother we have the story of his work during the whole winter of 1830. That his medical studies did not suffer from the fact that, in conjunction with them, he was carrying on his two great works 
on the living and the dead world of fishes may be inferred from the following account of his medical theses. It was written after his death, to his son Alexander Agassiz, by Professor von Siebold, now Director of the Museum in the University of Munich. "How earnestly Agassiz devoted himself to the study of medicine is shown by the theses (seventyfour in number), a list of which was printed, according to the prescribed rule and custom, with his 'Einladung.' I am astonished at the great number of these. The subjects are anatomical, pathological, surgical, obstetrical ; they are inquiries into materia medica, medicina forensis, and the relation of botany to these topics. One of them interested me especially. It read as follows. 'Foemina humana superior mare.' I would gladly have known how your father interpreted that sentence. Last fall (1873) I wrote him a letter, the last I ever addressed to him, questioning him about this very subject. That letter, alas! remained unanswered."

In a letter to his brother just before taking his degree, Agassiz says: "I am now determined to pursue medicine and natural history side by side. Thank you, with all my heart, for your disinterested offer, but I shall not 
need it, for I am going on well with my pub. lisher, M. Cotta, of Stuttgart. I have great hope that he will accept my works, since he has desired that they should be forwarded to him for examination. I have sent him the whole, and I feel very sure he will swallow the pill. My conditions would be the only cause of delay, but I hope he will agree to them. For the fresh-water fishes and the fossils together I have asked twenty thousand Swiss francs. Should he not consent to this, I shall apply to another publisher."

On the $3 \mathrm{~d}$ of April he received his degree of Doctor of Medicine. A day or two later he writes to his mother that her great desire for him is accomplished.

TO HIS MOTHER.

Munich, April, 1830.

. . My letter to-day must be to you, for to you I owe it that I have undertaken the work just completed, and I write to thank you for having encouraged my zeal. I am very sure that no letter from me has ever given you greater pleasure than this one will bring; and I can truly say, on my own part, that I have never written one with greater satisfaction. Yesterday I finished my medical ex- 
amination, after having satisfied every require. ment of the Faculty. . . The whole ceremony lasted nine days. At the close, while they considered my case, I was sent out of the room. On my return, the Dean said to me, "The Faculty have been very much" (emphasized) "pleased with your answers; they congratulate themselves on being able to give the diploma to a young man who has already acquired so honorable a reputation. On Saturday, after having argued your thesis, you will receive your degree, in the Academic Hall, from the Rector of the University." The Rector then added that he should look upon it as the brightest moment of his Rectorship when he conferred upon me the title I had so well merited. Next Saturday, then, at the very time you receive this letter, at ten o'clock in the morning, the discussion will have begun, and at twelve I shall have my degree. Dear Mother, dismiss all anxiety about me. You see I am as good as my word. ... Write soon; in a few days I go to Vienna for some months. ... 
FROM HIS MOTHER.

Orbe, April 7, 1830.

I cannot thank you enough, my dear Louis, for the happiness you have given me in completing your medical examinations, and thus securing to yourself a career as safe as it is honorable. It is a laurel added to those you have already won; in my eyes the most precious of all. You have for my sake gone through a long and arduous task; were it in my power I would gladly reward you, but I cannot even say that I love you the more for it, because that is impossible. My anxious solicitude for your future is a proof of my ardent affection for you; only one thing was wanting to make me the happiest of mothers, and this, my Louis, you have just given me. May God reward you by giving you all possible success in the care of your fellow-beings. May the benedictions which honor the memory of a good physician be your portion, as they have been in the highest degree that of your grandfather. Why can he not be here to share my happiness to-day in seeing my Louis a medical graduate!...

Agassiz was recalled from Vienna in less FOI. I. 
than two months by the arrival in Munich of his publisher, M. Cotta, a personal interview with whom seemed to him important. The only letter preserved from the Vienna visit shows that his short stay there was full of interest and instruction.

TO HIS FATHER.

Vienna, May 11, 1830.

... Since my arrival I have seen so much that I hardly know where to begin my narrative, and what I have seen has suggested reflections on many grave subjects, of a kind I had hardly expected to make here. Nowhere have I seen establishments on broader or more stately foundations, nor do I believe that anywhere are foreigners allowed more liberal use of like institutions. I speak of the university, the hospitals, libraries, and collections of all sorts. Neither have I seen anywhere else such fine churches, and I have more than once felt the difference between worshiping within bare walls, and in buildings more worthy of devotional purposes. In one word, I should be enchanted with my stay in Vienna if I could be free from the idea that I am always surrounded by an imperceptible net, ready to close upon me at the slightest signal. With 
this exception, the only discomfort to a foreigner here, if he is unaccustomed to it, is that of being obliged to abstain from all criticism of affairs in public places; still more must he avoid commenting upon persons. I am especially satisfied with my visit from a scientific point of view. I have learned, and am still learning, the care of the eyes and how to operate upon them; as to medicine, the physicians, however good, do not surpass those I have already known; and as I do not believe it important that a young physician should familiarize himself with a great variety of curative methods, I try to observe carefully the patient and his disease rather than to remember the medicaments applied in special cases. Surgery and midwifery are poorly provided, but one has a chance to see many interesting cases.

During the last fortnight I have visited the collection of natural history often, generally in the afternoon. To tell you how I have been expected there from the moment I was known to be here, and how I was received on my first visit, and have been fêted since (as Ichthyologus primus seculi, - so they say), would, perhaps, tire you and might seem egotistical in me, neither of which do I desire. 
But it will not be indifferent to you to know that Cotta is disposed to accept my Fishes. $\mathrm{He}$ has been at Munich for some days, and Schimper has been talking with him, and has advanced matters more by a few words than I had been able to do by much writing. For this reason I intend returning soon to Munich to complete the business, since Cotta is to be there several weeks longer. Thus I shall have reached my aim, and be provided from this autumn onward with an independent maintenance. I was often very anxious this past winter, in my uncertainty about the means of finally making good such large outlays. If, however, Cotta makes no other condition than that of a certain number of subscribers, I shall be sure of them in six months. You may thus regard what I have done as a speculation happily concluded, and one which places me at the summit of my desires, for it leaves me free, at last, to work upon my projects. ...

A letter to his brother, of the 29th of May, just after his return to Munich, gives a retrospect of the Viennese visit, including the personal details which he had hesitated to write to his father. They are important as showing 
the position he already, at twenty-three years of age, held among scientific men. "Everything," he says, "was open to me as a foreigner, and to my great surprise I was received as an associate already known. Was it not gratifying to go to Vienna with no recommendation whatever, and to be welcomed and sought by all the scientific men, and afterwards presented and introduced everywhere? In the Museum, not only were the rooms opened for me when I pleased, but also the cases, and even the jars, so that I could take out whatever I needed for examination. At the hospital several professors carried their kindness so far, as to invite me to accompany them in their private visits. You may fancy whether I profited by all this, and how many things I saw." After some account of his business arrangements with Cotta, he adds: "Meantime, be at ease about me. I have strings enough to my bow, and need not feel anxious about the future. What troubles me is that the thing I most desire seems to me, at least for the present, farthest from my reach, - namely, the direction of a great Museum. When I have finished with Cotta I shall begin to pack my effects, and shall hope to turn my face homeward somewhere about the end of August. I can 
hardly leave earlier, because, for the sake of practice, I have begun to deliver zoölogical lectures, open to all who like to attend, and I want to complete the course before my departure. I lecture without even an outline or headings before me, but this requires preparation. You see I do not lose my time."

The next home letter announces an important change in the family affairs. His father had been called from his parish at Orbe to that of Concise, a small town situated on the southwestern shore of the Lake of Neuchâtel.

FROM HIS MOTHER.

OrBe, July, 1830.

... Since your father wrote you on the 4th of June, dear Louis, we have had no news from you, and therefore infer that you are working with especial zeal to wind up your affairs in Germany and come home as soon as possible. Whatever haste you make, however, you will not find us here. Four days ago your father became pastor of Concise, and yesterday we went to visit our new home. Nothing can be prettier, and by all who know the place it is considered the most desirable position in the canton. There is a vineyard, a fine orchard filled with fruit-trees in full bear. 
ing, and an excellent kitchen garden. A never-failing spring gushes from a grotto, and within fifty steps of the house is a pretty winding stream with a walk along the bank, bordered by shrubbery, and furnished here and there with benches, the whole disposed with much care and taste. The house also is very well arranged. All the rooms look out upon the lake, lying hardly a gunshot from the windows. There are a parlor and a dining-room on the first floor, beside two smaller rooms; and on the same floor two doors lead out into the flower garden. The kitchen is small, and on one side is a pretty ground where we can dine in the open air in summer. The distribution of rooms in the upper story is the same, with a large additional room for the accommodation of your father's catechumens. A jasmine vine drapes the front of the house and climbs to the very roof. ...

To this quiet pretty parsonage Madame Agassiz became much attached. Her tranquil life is well described in a letter written many years afterward by one of her daughters. "Here mama returned to her spinning-wheel with new ardor. It was a work she much liked, and in which she was very skillful. In 
former times at grandpapa's every woman in the house, whether mistress or maid, had her wheel, and the young ladies were accustomed to spin and make up their own trousseaus. Later, mama continued her spinning for her children, and even for her grandchildren. We all preserve as a precious souvenir, table linen of her making. We delighted to see her at her wheel, she was so graceful, and the thread of her thought seemed to follow, so to speak, the fine and delicate thread of her work as it unwound itself under her touch from the distaff."

Agassiz was detained by his publishing arrangements and his work longer than he had expected, and November was already advanced before his preparations for leaving Munich were completed.

TO HIS PARENTS.

Munich, November 9, 1830.

... According to your wish [this refers to a suggestion about a fellow-student in a previous letter] I shall not bring any friend with me. I long to enjoy the pleasure of family life. I shall, however, be accompanied by one person, for whom I should like to make suitable arrangements. He is the 
artist who makes all my drawings. If there is no room for him in the house he can be lodged elsewhere; but I wish you could give me the use of a well-lighted room, where I could work and he could draw at my side through the day. Do not be frightened; he is not at my charge; but it would be a great advantage to me if I could have him in the house. As I do not want to lose time in the mechanical part of my work, I would beg papa to engage for me some handy boy, fifteen years old or so, whom I could employ in cleaning skeletons and the like. Finally, you will receive several boxes for me; leave them unopened till I come, without even paying the freight upon them, - the most unsatisfactory of all expenses; - and I do not wish you to have an unpleasant association with my collections.

My affairs are all in order with Cotta, and I have even concluded the arrangement more advantageously than I had dared to hope, a thousand louis, six hundred payable on the publication of the first number, and four hundred in installments, as the publication goes on. If I had not been in haste to close the matter in order to secure myself against all doubt, I might have done even better. But I 
hope I have reconciled you thereby to Natural History. What remains to be done will be the work of less than half a year, during which I wish also to get together the materials for my second work, on the fossils. Of that I have already spoken with my publisher, and he will take it on more favorable conditions than I could have dictated. Do your best to fund me subscribers, that we may soon make our typographical arrangements. . . .

His father's answer, full of fun as it is, shows, nevertheless, that the prospect of domesticating not only the naturalist and his collections, but artist and assistant also, was rather startling.

\section{FROII HIS FATHER.}

Concise, November 16, 1830.

... You speak of Christmas as the moment of your arrival; let us call it the New Year. You will naturally pass some days at Neuchâtel to be with your brother, to see the Messrs. Coulon, etc.; from there to Cudrefin for a look at your collection; then to Concise, then to Montagny, Orbe, Lausanne, Geneva, etc.: M. le Docteur will be claimed and fêted by all in turn. And during all 
these indispensable excursions, for which, to be within bounds, I allow a month at least, it is as clear as daylight that regular work must be set aside, if, indeed, the time be not wholly lost. Now, for Heaven's sake, what will you do, or rather what shall we do, with your painter, in this interval employed by you elsewhere. Neither is this all. Though the date of Cecile's marriage is not fixed, it is more than likely to take place in January, so that you will be here for the wedding. If you will recollect the overturning of the paternal mansion when your outfit was preparing for Bienne, Zurich, and other places, you can form an idea of the state of our rooms above and below, large and small, when the work of the trousseau begins. Where, in Heaven's name, will you stow away a painter and an assistant in the midst of half a brigade of dress-makers, seamstresses, lace-makers, and milliners, without counting the accompanying train of friends? Where would you, or where could you, put under shelter your possessions (I dare not undertake to enumerate them), among all the taffetas and brocades, linens, muslin, tulles, laces, etc.? But what am I saying? I doubt if these names are still in existence, for quite other appellations are sound- 
ing in my ears, each one of which, to the number of some hundred, signifies at least twenty yards in width, to say nothing of the length. For my part, I have already, notwithstanding the approach of winter, put up a big nail in the garret, on which to hang my bands and surplice. Listen, then, to the conclusion of your father. Give all possible care to your affairs in Munich, put them in perfect order, leave nothing to be done, and leave nothing behind except the painter. You can call him in from here, whenever you think you can make use of him.

\section{TO HIS PARENTS.}

Munici, November 26, 1830.

... When you receive this I shall be no longer in Munich; by means of a last draft on M. Eichthal I have settled with every one, and I hope to leave the day after to-morrow. I fully recognize the justice of your observations, my dear father, but as you start from a mistaken point of view, they do not coincide altogether with existing circumstances. I intend to stay with you until the approach of summer, not only with the aim of working upon the text of my book, but chiefly in order to take advantage of all the fossil collections 
in Switzerland. For that purpose I positively need a draughtsman, who, thanks to my publisher, is not in my pay, and who must accompany me in future wherever I go. Since there is no room at home, please see how he can be lodged in the neighborhood. I have, at the utmost, to glance each day at what he has done. I can even give him work for several weeks in which my presence would be unnecessary. If there is a considerable collection of fossils at Zurich, I shall leave him there till he has finished his work, and then he will rejoin me; all that depends upon circumstances. In any case he must not be a charge to you, still less interfere with our family privacy. That I may spend all my time with you, I shall at present bring with me nothing that is not absolutely necessary. We shall see later where I shall place my museum. As to visits, they are not to be thought of until the spring. I could not bear the idea of interruption before the first number of my "Fishes" is finished.

The artist in question was Mr. Dinkel. His relations with the family became of a truly friendly character. The connection between him and Agassiz, most honorable to both par- 
ties, lasted for sixteen years, and was then only interrupted by the departure of Agassiz for America. During this whole period Mr. Dinkel was occupied as his draughtsman, living sometimes in Paris, sometimes in England, sometimes in Switzerland, wherever, in short, there were specimens to be drawn. In a private letter, written long afterward, he says, in speaking of the break in their intercourse caused by Agassiz's removal to America: "For a long time I felt unhappy at that separation. . . He was a kind, noble-hearted friend; he was very benevolent, and if he had possessed millions of money he would have spent them for his researches in science, and have done good to his fellow-creatures as much as possible."

Some passages from Braun's letters complete the chapter of these years in Munich, so rich in purpose and in experience, the prelude, as it were, to the intellectual life of the two friends who had entered upon them together. These extracts show how seriously, not without a certain sadness, they near the end. 
BRAUN TO HIS FATHER.

Munich, November 7, 1830.

Were I to leave Munich now, I must separate myself from Agassiz and Schimper, which would be neither agreeable nor advantageous for me, nor would it be friendly toward them. We will not shorten the time, already too scantly measured, which we may still spend so quietly, so wholly by ourselves, but rather, as long as it lasts, make the best use of it in a mutual exchange of what we have learned, trying to encourage each other in the right path, and drawing more closely together for our whole life to come. Agassiz is to stay till the end of the month; during this time he will give us lectures in anatomy, and I shall learn a good deal of zoölogy. Beside all this one thing is certain; namely, that we can review our medical work much more quietly and uninterruptedly here than in Carlsruhe. Add to this, the advantage we enjoy here of visiting the hospitals. ... The time passes delightfully with us of late, for Agassiz has received several baskets of books from Cotta, among others, Schiller's and Goethe's complete works, the Conversations-Lexicon, medical works, and works on natural history. How many books 
a man may receive in return for writing only one! They are, of course, deducted from his share of the profits. Yesterday we did nothing but read Goethe the whole day.

A brief account of Agassiz's university life, dictated by himself, may fitly close the record of this period. He was often urged to put together a few reminiscences of his life, but he lived so intensely in the present, every day bringing its full task, that he had little time for retrospect, and this sketch remained a fragment. It includes some facts already told, but is given almost verbatim, because it forms a sort of summary of his intellectual development up to this date.

"I am conscious that at successive periods of my life I have employed very different means and followed very different systems of study. I may, therefore, be allowed to offer the result of my experience as a contribution toward the building up of a sound method for the promotion of the study of nature.

"At first, when a mere boy, twelve years of age, I did what most beginners do. I picked up whatever I could lay my hands on, and tried, by such books and authorities as I had at my command, to find the names of these 
objects. My highest ambition, at that time, was to be able to designate the plants and animals of my native country correctly by a Latin name, and to extend gradually a similar knowledge in its application to the productions of other countries. This seemed to me, in those days, the legitimate aim and proper work of a naturalist. I still possess manuscript volumes in which $I$ entered the names of all the animals and plants with which I became acquainted, and I well remember that I then ardently hoped to acquire the same superficial - familiarity with the whole creation. I did not then know how much more important it is to the naturalist to understand the structure of a few animals, than to command the whole field of scientific nomenclature. Since I have become a teacher, and have watched the progress of students, I have seen that they all begin in the same way; but how many have grown old in the pursuit, without ever rising to any higher conception of the study of nature, spending their life in the determination of species, and in extending scientific terminology! Long before I went to the university, and before I began to study natural history under the guidance of men who were masters in the science during the early part of VOL. I. 
this century, I perceived that while nomenclature and classification, as then understood, formed an important part of the study, being, in fact, its technical language, the study of - living beings in their natural element was of infinitely greater value. At that age, namely, about fifteen, I spent most of the time I could spare from classical and mathematical studies in hunting the neighboring woods and meadows for birds, insects, and land and freshwater shells. My room became a little menagerie, while the stone basin under the fountain in our yard was my reservoir for all the fishes I could catch. Indeed, collecting, fishing, and raising caterpillars, from which I reared fresh, beautiful butterflies, were then my chief pastimes. What I know of the habits of the fresh-water fishes of Central Europe I mostly learned at that time; and I may add, that when afterward I obtained access to a large library and could consult the works of Bloch and Lacépède, the only extensive works on fishes then in existence, I wondered that they contained so little about their habits, natural attitudes, and mode of action with which I was so familiar.

"The first course of lectures on zoölogy I attended was given in Lausanne in 1823. It 
consisted chiefly of extracts from Cuvier's 'Règne Animal,' and from Lamarck's 'Animaux sans Vertèbres.' I now became aware, for the first time, that the learned differ in their classifications. With this discovery, an immense field of study opened before me, and I longed for some knowledge of anatomy, that I might see for myself where the truth was. During two years spent in the Medical School of Zurich, I applied myself exclusively to the study of anatomy, physiology, and zoölogy, under the guidance of Professors Schinz and Hirzel. My inability to buy books was, perhaps, not so great a misfortune as it seemed to me; at least, it saved me from too great dependence on written authority. I spent all my time in dissecting animals and in studying human anatomy, not forgetting my favorite amusements of fishing and collecting. I was - always surrounded with pets, and had at this time some forty birds flying about my study, with no other home than a large pine-tree in the corner. I still remember my grief when a visitor, entering suddenly, caught one of my little favorites between the floor and the door; and he was killed before I could extricate him. Professor Schinz's private collection of birds was my daily resort, and I then described every 
- bird it contained, as I could not afford to buy even a text-book of ornithology. I also copied with my own hand, having no means of purchasing the work, two volumes of Lamarck's 'Animaux sans Vertèbres,' and my dear brother copied another half volume for me. I finally learned that the study of the things - themselves was far more attractive than the books I so much coveted; and when, at last, large libraries became accessible to me, I usually contented myself with turning over the leaves of the volumes on natural history, looking at the illustrations, and recording the titles of the works, that I might readily consult them for identification of such objects as I should have an opportunity of examining in nature.

"After spending in this way two years in Zurich, I was attracted to Heidelberg by the great reputation of its celebrated teachers, Tiedemann, Leuckart, Bronn, and others. It is true that I was still obliged to give up a part of my time to the study of medicine, but while advancing in my professional course by a steady application to anatomy and physiology, $\mathrm{I}$ attended the lectures of Leuckart in zoölogy, and those of Bronn in paleontology. The publication of Goldfuss's great work on the fossils 
of Germany was just then beginning, and it opened a new world to me. Familiar as I was with Cuvier's ' Règne Animal,' I had not then seen his 'Researches on Fossil Remains,' and the study of fossils seemed to me only an extension of the field of zoölogy. I had no idea of its direct connection with geology, or of its bearing on the problem of the successive introduction of animals on the earth. I had never thought of the larger and more philosophical view of nature as one great world, but considered the study of animals only as it was taught by descriptive zoölogy in those days. At about this time, however, I made the acquaintance of two young botanists, Braun and Schimper, both of whom have since become distinguished in the annals of science. Botany had in those days received a new impulse from the great conceptions of Goethe. The metamorphosis of plants was the chief study of my friends, and I could not but feel that descriptive zoölogy had not spoken the last word in our science, and that grand generalizations, such as were opening upon botanists, must be preparing for zoölogists also. Intimate contact with German students made me feel that I had neglected my philosophical education; and when, in the 
year 1827, the new University of Munich opened, with Schelling as professor of philosophy, Oken, Schubert, and Wagler as professors of zoölogy, Döllinger as professor of anatomy and physiology, Martius and Zuccarini as professors of botany, Fuchs and Kobell as professors of mineralogy, I determined to go there with my two friends and drink new draughts of knowledge. During the years I passed at Munich I devoted myself almost exclusively to the different branches of natural science, neglecting more and more my medical studies, because I began to feel an increasing confidence that I could fight my way in the world as a naturalist, and that I was therefore justified in following my strong bent in that direction. My experience in Munich was very varied. With Döllinger I learned to value accuracy of observation. As I was living in his house, he gave me personal instruction in the use of the microscope, and showed me his own methods of embryological investigation. He had already been the teacher of Karl Ernst von Baer; and though the pupil outran the master, and has become the pride of the scientific world, it is but just to remember that he owed to him his first initiation into the processes of embryological research. Döllin. 
ger was a careful, minute, persevering observer, as well as a deep thinker; but he was as indolent with his pen as he was industrious with his brain. He gave his intellectual capital to his pupils without stint or reserve, and nothing delighted him more than to sit down for a quiet talk on scientific matters with a few students, or to take a ramble with them into the fields outside the city, and explain to them as he walked the result of any recent investigation he had made. If he found himself understood by his listeners he was satisfied, and cared for no farther publication of his researches. I could enumerate many works of masters in our science, which had no other foundation at the outset than these inspiriting conversations. No one has borne warmer testimony to the influence Döllinger has had in this indirect way on the progress of our science than the investigator I have already mentioned as his greatest pupil, - von Baer. In the introduction to his work on embryology he gratefully acknowledges his debt to his old teacher.

"Among the most fascinating of our professors was Oken. A master in the art of teaching, he exercised an almost irresistible influence over his students. Constructing the 
universe out of his own brain, deducing from a priori conceptions all the relations of the three kingdoms into which he divided all living beings, classifying the animals as if by magic, in accordance with an analogy based on the dismembered body of man, it seemed to us who listened that the slow laborious process of accumulating precise detailed knowledge could only be the work of drones, while a generous, commanding spirit might build the world out of its own powerful imagina- tion. The temptation to impose one's own ideas upon nature, to explain her mysteries by brilliant theories rather than by patient study of the facts as we find them, still leads us away. With the school of the physio-philosophers began (at least in our day and generation) that overbearing confidence in the abstract conceptions of the human mind as applied to the study of nature, which still impairs the fairness of our classifications and prevents them from interpreting truly the natural relations binding together all living beings. And yet, the young naturalist of that day who did not share, in some degree, the intellectual stimulus given to scientific pursuits by physio-philosophy would have missed a part of his training. There is a great dis- 
tance between the man who, like Oken, attempts to construct the whole system of nature from general premises and the one who, while subordinating his conceptions to the facts, is yet capable of generalizing the facts, of recognizing their most comprehensive relations. No thoughtful naturalist can silence the suggestions, continually arising in the course of his investigations, respecting the origin and deeper connection of all living beings; but he is the truest student of nature who, while seeking the solution of these great problems, admits that the only true scientific system must be one in which the thought, the intellectual structure, rises out of and is based upon facts. The grẹat merit of the physiophilosophers consisted in their suggestiveness. They did much in freeing our age from the low estimation of natural history as a science which prevailed in the last century. They stimulated a spirit of independence among observers; but they also instilled a spirit of daring, which, from its extravagance, has been - fatal to the whole school. He is lost, as an observer, who believes that he can, with impunity, affirm that for which he can adduce no evidence. It was a curious intellectual experience to listen day after day to the lec- 
tures of Oken, while following at the same time Schelling's courses, where he was shifting the whole ground of his philosophy from its negative foundation as an a priori doctrine to a positive basis, as an historical science. He unfolded his views in a succession of exquisite lectures, delivered during four consecutive years.

"Among my fellow-students were many young men who now rank among the highest lights in the various departments of science, and others, of equal promise, whose early death cut short their work in this world. Some of us had already learned at this time to work for ourselves; not merely to attend lectures and study from books. The best spirit of emulation existed among us; we met often to discuss our observations, undertook frequent excursions in the neighborhood, delivered lectures to our fellow-students, and had, not infrequently, the gratification of seeing our university professors among the listeners. These exercises were of the highest value to me as a preparation for speaking, in later years, before larger audiences. My study was usually the lecture-room. It would hold conveniently from fifteen to twenty persons, - and both students and professors used to call 
our quarters "The Little Academy." In that room I made all the skeletons represented on the plates of Wagler's "Natural System of Reptiles;" there I once received the great anatomist, Meckel, sent to me by Döllinger, to examine my anatomical preparations and especially the many fish-skeletons I had made

- from fresh-water fishes. By my side were constantly at work two artists; one engaged in drawing various objects of natural history, the other in drawing fossil fishes. I kept always one and sometimes two artists in my pay; it was not easy, with an allowance of $\$ 250$ a year, but they were even poorer than I, and so we managed to get along together. My microscope I had earned by writing.

"I had hardly finished the publication of the Brazilian Fishes, when I began to study the works of the older naturalists. Professor Döllinger had presented me with a copy of Rondelet, which was my delight for a long time. I was especially struck by the naïveté of his narrative and the minuteness of his descriptions as well as by the fidelity of his woodcuts, some of which are to this day the best figures we have of the species they represent. His learning overwhelmed me; I would gladly have read, as he did, everything that had been written before my time; but there were au- 
thors who wearied me, and I confess that at that age Linnæus was among the number. I found him dry, pedantic, dogmatic, conceited; while I was charmed with Aristotle, whose zoölogy I have read and re-read ever since at intervals of two or three years. I must, however, do myself the justice to add, that after I knew more of the history of our science I learned also duly to reverence Linnæus. But a student, already familiar with the works of Cuvier, and but indifferently acquainted with the earlier progress of zoölogy, could hardly appreciate the merit of the great reformer of natural history. His defects were easily perceived, and it required more familiarity than mine then was with the gradual growth of the science, from Aristotle onward, to understand how great and beneficial an influence Linnæus had exerted upon modern natural history.

"I cannot review my Munich life without deep gratitude. The city teemed with resources for the student in arts, letters, philosophy, and science. It was distinguished at that time for activity in public as well as in academic life. The king seemed liberal; he was the friend of poets and artists, and aimed at concentrating all the glories of Germany in his new university. I thus enjoyed for a 
few years the example of the most brilliant intellects, and that stimulus which is given by competition between men equally eminent in different spheres of human knowledge. Under such circumstances a man either subsides into the position of a follower in the ranks that gather around a master, or he aspires to be a master himself.

"The time had come when even the small allowance I received from borrowed capital must cease. I was now twenty-four years of age. I was Doctor of Philosophy and Medicine, and author of a quarto volume on the fishes of Brazil. I had traveled on foot all over Southern Germany, visited Vienna, and explored extensive tracts of the Alps. I knew every animal, living and fossil, in the $\mathrm{Mu}$ seums of Munich, Stuttgart, Tübingen, Erlangen, Wurzburg, Carlsruhe, and Frankfort; but my prospects were as dark as ever, and I saw no hope of making my way in the world, except by the practical pursuit of my profession as physician. So, at the close of 1830, I left the university and went home, with the intention of applying myself to the practice of medicine, confident that my theoretical information and my training in the art of observing would carry me through the new ordeal I was about to meet." 


\section{CHAPTER V.}

$1830-1832$ : «T. $23-25$.

Year at Home. - Leaves Home for Paris. - Delays on the Road. - Cholera. - Arrival in Paris. - First Visit to Cavier. - Cuvier's Kindness. - His Death. - Poverty in Paris. - Home Letters concerning Embarrassments and about his Work. - Singular Dream.

ON the 4th of December, 1830, Agassiz left Munich, in company with Mr. Dinkel, and after a short stay at St. Gallen and Zurich, spent in looking up fossil fishes and making drawings of them, they reached Concise on the 30th of the same month. Anxiously as his return was awaited at home, we have seen that his father was not without apprehension lest the presence of the naturalist, with artist, specimens, and apparatus, should be an incon-

- venience in the quiet parsonage. But every obstacle yielded to the joy of reunion, and Agassiz was soon established with his "painter," his fossils, and all his scientific outfit, under the paternal roof.

Thus quietly engaged in his ichthyological studies, carrying on his work on the fossil 
fishes, together with that on the fresh-water fishes of Central Europe, he passed nearly a year at home. He was not without patients also in the village and its environs, but had, as yet, no prospect of permanent professional employment. In the mean time it seemed daily more and more necessary that he should carry his work to Paris, to the great centre of scientific life, where he could have the widest field for comparison and research. There, also, he could continue and complete to the best advantage his medical studies. His poverty was the greatest hindrance to any such move. He was not, however, without some slight independent means, especially since his publishing arrangements provided in part for the carrying on of his work. His generous uncle added something to this, and an old friend of his father's, M. Christinat, a Swiss clergyman with whom he had been from boyhood a great favorite, urged upon him his own contribution toward a work in which he felt the liveliest interest. Still the prospect with which he left for Paris in September, 1831, was dark enough, financially speaking, though full of hope in another sense. On the road he made several halts for purposes of study, combining, as usual, professional with scien- 
tific objects, hospitals with museums. He was, perhaps, a little inclined to believe that the most favorable conditions for his medical studies were to be found in conjunction with the best collections. He had, however, a special medical purpose, being earnest to learn everything regarding the treatment and the limitation of cholera, then for the first time making its appearance in Western Europe with frightful virulence. Believing himself likely to continue the practice of medicine for some years at least, he thought his observations upon this scourge would be of great importance to him. His letters of this date to his father are full of the subject, and of his own efforts to ascertain the best means of prevention and defense. The following answer to an appeal from his mother shows, however, that his delays caused anxiety at home, lest the small means he could devote to his studies in Paris should be consumed on the road.

TO HIS MOTHER.

Carlsrune, November, 1831.

... I returned day before yesterday from my trip in Würtemberg, and though I already knew what precautions had been taken everywhere in anticipation of cholera, I do 
not think my journey was a useless one, and am convinced that my observations will not be without interest, - chiefly for myself, of course, but of utility to others also I hope. Your letter being so urgent, I will not, however, delay my departure an instant. Between to-day and to-morrow I shall put in order the specimens lent me by the Museum, and then start at once. . . . In proportion to my previous anxiety is my pleasure in the prospect of going to Paris, now that I am better fitted to present myself there as I could wish. I have collected for my fossil fishes all the materials I still desired to obtain from the museums of Carlsruhe, Heidelberg, and Strasbourg, and have extended my knowledge of geology sufficiently to join, without embarrassment at least, in conversation upon the more recent researches in that department. Moreover, Braun has been kind enough to give me a superb collection, selected by himself, to serve as basis and guide in my researches. I leave it at Carlsruhe, since I no longer need it. . . . I have also been able to avail myself of the Museum of Carlsiuhe, and of the mineralogral collection of Braun's father. Beside the drawings made by Dinkel, I have added to my work one hundred and seventy-one pages VOL. I. 
of manuscript in French ( $\mathrm{I}$ have just counted them), written between my excursions and in the midst of other occupations. . . . I could not have foreseen so rich a harvest.

Thus prepared, he arrived in Paris with his artist on the 16th of December, 1831. On the 18th he writes to his father. . . " Dinkel and I had a very pleasant journey, though the day after our arrival I was so fatigued that I could hardly move hand or foot, - that was yesterday. Nevertheless, I passed the evening very agreeably at the house of M. Cuvier, who sent to invite me, having heard of my arrival. To my surprise, I found myself not quite a stranger, - rather, as it were, among old acquaintances. I have already given you my address, Rue Copeau (Hôtel du Jardin du Roi, No. 4). As it happens, M. Perrotet, a traveling naturalist, lives here also, and has at once put me on the right track about whatever I most need to know. There are in the house other well-known persons besides. I am accommodated very cheaply, and am at the same time within easy reach of many things, the neighborhood of which I can turn to good account. The medical school, for instance, is within ten minutes' walk; the Jardin des 
Plantes not two hundred steps away; while the Hospital (de la Pitié), where Messieurs Andral and Lisfranc teach, is opposite, and nearer still. To-day or to-morrow I shall deliver my letters, and then set to work in good earnest."

Pleased as he was from the beginning with all that concerned his scientific life in Paris, the next letter shows that the young Swiss did not at once find himself at home in the great French capital.

TO HIS SISTER OLYMPE.

PARIS, January 15, 1832.

... My expectations in coming here have been more than fulfilled. In scientific matters I have found all that I knew must exist in Paris (indeed, my anticipations were rather below than above the mark), and beside that I have been met everywhere with courtesy, and have received attentions of all sorts. M. Cuvier and M. Humboldt especially treat me on all occasions as an equal, and facilitate for me the use of the scientific collections so that I can work here as if I were at home. And yet it is not the same thing; this extreme, but formal politeness chills you instead of putting you at your ease; it lacks cordiality, 
and, to tell the truth, I would gladly go away were I not held fast by the wealth of material of which I can avail myself for instruction. In the morning I follow the clinical courses at the Pitié. . . At ten o'clock, or perhaps at eleven, I breakfast, and then go to the Museum of Natural History, where I stay till dark. Between five and six I dine, and after that turn to such medical studies as do not require daylight. So pass my days, one like another, with great regularity. I have made it a rule not to go out after dinner, - I should lose too much time. . . . On Saturday only I spend the evening at $\mathrm{M}$. $\mathrm{Cu}$ vier's. . . .

The homesickness which is easily to be read between the lines of this letter, due, perhaps, to the writer's want of familiarity with society in its conventional aspect, yielded to the influence of an intellectual life, which became daily more engrossing. Cuvier's kind reception was but an earnest of the affectionate interest he seems from the first to have felt in him. After a few days he gave Agassiz and his artist a corner in one of his own laboratories, and often came to encourage them by a glance at their work as it went on. 
This relation continued until Cuvier's death, and Agassiz enjoyed for several months the scientific sympathy and personal friendship of . the great master whom he had honored from childhood, and whose name was ever on his lips till his own work in this world was closed. The following letter, written two months later, to his uncle in Lausanne tells the story in detail.

TO DR. MAYOR.

PARIs, February 16, 1832.

-.. I have also a piece of good news to communicate, which will, I hope, lead to very favorable results for me. I think I told you when I left for Paris that my chief anxiety was lest I might not be allowed to examine, and still less to describe, the fossil fishes and their skeletons in the Museum. Knowing that Cuvier intended to write a work on this subject, I supposed that he would reserve these specimens for himself. I half thought he might, on seeing my work so far advanced, propose to me to finish it jointly with him, - but even this I hardly dared to hope. It was on this account, with the view of increasing my materials and having thereby a better chance of success with M. Cuvier, that I 
desired so earnestly to stop at Strasbourg and Carlsruhe, where I knew specimens were to be seen which would have a direct bearing on my aim. The result has far surpassed my expectation. I hastened to show my material to M. Cuvier the very day after my arrival. He received me with great politeness, though with a certain reserve, and immediately gave me permission to see everything in the galleries of the Museum. But as I knew that he had put together in private collections all that could be of use to himself in writing his book, and as he had never said a word to me of his plan of publication, I remained in a painful state of doubt, since the completion of his work would have destroyed all chance for the sale of mine. Last Saturday I was passing the evening there, and we were talking of science, when he desired his secretary to bring him a certain portfolio of drawings. He showed me the contents; they were drawings of fossil fishes and notes which he had taken in the British Museum and elsewhere. After looking it through with me, he said he had seen with satisfaction the manner in which I had treated this subject; that I had indeed anticipated him, since he had intended at some future time to do the same thing; 
but that as I had given it so much attention, and had done my work so well, he had decided to renounce his project, and to place at my disposition all the materials he had collected and all the preliminary notes he had taken.

You can imagine what new ardor this has given me for my work, the more so because M. Cuvier, M. Humboldt, and several other persons of mark who are interested in it have promised to speak in my behalf to a publisher (to Levrault, who seems disposed to undertake the publication should peace be continued), and to recommend me strongly. To accomplish my end without neglecting other occupations, I work regularly at least fifteen hours a day, sometimes even an hour or two more; but I hope to reach my goal in good time.

This trust from Cuvier proved to be a legacy. Less than three months after the date of this letter Agassiz went, as often happened, to work one morning with him in his study. It was Sunday, and he was employed upon something which Cuvier had asked him to do, saying, "You are young; you have time enough for it, and I have none to spare." They worked together till eleven o'clock, when $\mathrm{Cu}$ vier invited Agassiz to join him at brealzfast. 
After a little time spent over the breakfast table in talk with the ladies of the family, while Cuvier opened his letters, papers, etc., they returned to the working room, and were busily engaged in their separate occupations when Agassiz was surprised to hear the clock strike five, the hour for his dinner. He expressed his regret that he had not quite finished his work, but said that as he belonged to a student's table his dinner would not wait for him, and he would return soon to complete his task. Cuvier answered that he was quite right not to neglect his regular hours for meals, and commended his devotion to study, but added, "Be careful, and remember that work kills." They were the last words he heard from his beloved teacher. The next day, as Cuvier was going up to the tribune in the Chamber of Deputies, he fell, was taken up paralyzed, and carried home. Agassiz never saw him again. ${ }^{1}$

In order to keep intact these few data respecting his personal relations with Cuvier, as told in later years by Agassiz himself, the

1 This warning of Cuvier, "Work kills," strangely recalls Johannes Müller's "Blood clings to work;" the one seems the echo of the other. See Memoir of Johannes Müller, by Rudolf Virchow, p. 38. 
course of the narrative has been anticipated by a month or two. Let us now return to the natural order. The letter to his uncle of course gave great pleasure at home. Just after reading it his father writes (February, 1832), "Now that you are intrusted with the portfolio of M. Cuvier, I suppose your plan is considerably enlarged, and that your work will be of double volume; tell me, then, as much about it as you think I can understand, which will not be a great deal after all." His mother's letter on the same occasion is full of tender sympathy and gratitude.

Meanwhile one daily anxiety embittered his scientific happiness. The small means at his command could hardly be made, even with the strictest economy, to cover the necessary expenses of himself and his artist, in which were included books, drawing materials, fees, etc. He was in constant terror lest he should be obliged to leave Paris, to give up his investigations on the fossil fishes, and to stop work on the costly plates he had begun. The truth about his affairs, which he would gladly have concealed from those at home as long as possible, was drawn from him by an accidental occurrence. His brother had written to him for a certain book, and, failing to receive 
it, inquired with some surprise why his commission was neglected. Agassiz's next letter, about a month later than the one to his uncle, gives the explanation.

TO HIS BROTHER.

Paris, March, 1832.

. . Here is the book for which you asked me, - price, 18 francs. I shall be very sorry if it comes too late, but I could not help it. ... In the first place I had not money enough to pay for it without being left actually penniless. You can imagine that after the fuel bill for the winter is paid, little remains for other expenses out of my 200 francs a month, five louis of which are always due to my companion. Far from having anything in advance, my month's supply is thus taken up at once.... Beside this cause of delay, you can have no idea what it is to hunt for anything in Paris when you are a stranger there. As I go out only in two or three directions leading to my work, and might not otherwise leave my own street for a month at a time, I naturally find myself astray when I am off this beaten track. . . . You have asked me several times how I have been received by those to whom I had introductions. Frankly, after 
having delivered a few of my letters, I have never been again, because I cannot, in my position, spare time for visits. . . Another excellent reason for staying away now is that I have no presentable coat. At M. Cuvier's only am I sufficiently at ease to go in a frock coat. . . . Saturday, a week ago, M. de Férussac offered me the editorship of the zoölogical section of the "Bulletin;" it would be worth to me an additional thousand francs, but would require two or three hours' work daily. Write me soon what you think about it. In the midst of all the encouragements which sustain me and renew my ardor, I am depressed by the reverse side of my position.

This letter drew forth the following one.

FROM HIS MOTHER.

Concise, March, 1832.

... Much as your letter to your uncle delighted us, that to your brother has saddened us. It seems, my dear child, that you are painfully straitened in means. I understand it by personal experience, and in your case I have foreseen it; it is the cloud which has always darkened your prospects to me. I want to talk to you, my dear Louis, of your 
future, which has often made me anxious. You know your mother's heart too well to misunderstand her thought, even should its expression be unacceptable to you. With much knowledge, acquired by assiduous industry, you are still at twenty-five years of age living on brilliant hopes, in relation, it is true, with great people, and known as having distinguished talent. Now, all this would seem to me delightful if you had an income of fifty thousand francs; but, in your position, you must absolutely have an occupation which will enable you to live, and free you from the insupportable weight of dependence on others. From this day forward, my dear child, you must look to this end alone if you would find it possible to pursue honorably the career you have chosen. Otherwise constant embarrassments will so limit your genius, that you will fall below your own capacity. If you follow our advice you will perhaps reach the result of your work in the natural sciences a little later, but all the more surely. Let us see how you can combine the work to which you have already consecrated so much time, with the possibility of self-support. It appears from your letter to your brother that you see no one in Paris; the reason seems to me a sad one, but it 
is unanswerable, and since you cannot change it, you must change your place of abode and return to your own country. You have already seen in Paris all those persons whom you thought it essential to see; unless you are strangely mistaken in their good-will, you will be no less sure of it in Switzerland than in Paris, and since you cannot take part in their society, your relations with them will be the same at the distance of a hundred leagues as they are now. You must therefore leave Paris for Geneva, Lausanne, or Neuchâtel, or any city where you can support yourself by teaching. . . . This seems to me the most advantageous course for you. If before fixing yourself permanently you like to take your place at the parsonage again, you will always find us ready to facilitate, as far as we can, any arrangements for your convenience. Here you can live in perfect tranquillity and without expense.

There are two other subjects which I want to discuss with you, though perhaps I shall not make myself so easily understood. You have seen the handsome public building in process of construction at Neuchâtel. It will be finished this year, and I am told that the Museum will be placed there. I believe the 
collections are very incomplete, and the city of Neuchâtel is rich enough to expend something in filling the blanks. It has occurred to me, my dear, that this would be an excellent opportunity for disposing of your alcoholic specimens. They form, at present, a capital yielding no interest, requiring care, and to be enjoyed only at the cost of endless outlay in glass jars, alcohol, and transportation, to say nothing of the rent of a room in which to keep them. All this, beside attracting many visitors, is too heavy a burden for you, from which you may free yourself by taking advantage of this rare chance. To this end you must have an immediate understanding with M. Coulon, lest he should make a choice elsewhere. Your brother, being on the spot, might negotiate for you. . . Finally, my last topic is Mr. Dinkel. You are very fortunate to have found in your artist such a thoroughly nice fellow; nevertheless, in view of the expense, you must make it possible to do without him. I see you look at me aghast; but where a sacrifice is to be made we must not do it by halves; we must pull up the tree by the roots. It is a great evil to be spending more than one earns. . . 
TO HIS MOTHER.

PARIS, March 25, 1832.

... It is true, dear mother, that I am greatly straitened; that I have much less money to spend than I could wish, or even than I need; on the other hand, this makes me work the harder, and keeps me away from distractions which might otherwise tempt me. ... With reference to my work, however, things are not quite as you suppose, as regards either my stay here or my relations with M. Cuvier. Certainly, I hope that I should lose neither his good-will nor his protection on leaving here; on the contrary, I am sure that he would be the first to advise me to accept any professorship, or any place which might be advantageous for me, however removed from my present occupations, and that his counsels would follow me there. But what cannot follow me, and what I owe quite as much to him, is the privilege of examining all the collections. These I can have nowhere but in Paris, since even if he would consent to it I could not carry away with me a hundred quintals of fossil fish, which, for the sake of comparison, I must have before my eyes, nor thousands of fish-skeletons, which would alone 
fill some fifty great cases. It is this which compels me to stay here till I have finished my work. I should add that M. Elie de Beaumont has also been kind enough to place at my disposition the fossil fishes from the collection at the Mining School, and that M. Brongniart has made me the same offer regarding his collection, which is one of the finest among those owned by individuals in Paris. ...

As to my collections, I had already thought of asking either the Vaudois government or the city of Neuchâtel to receive them into the Museum, merely on condition that they should provide for the expenses of exhibition and preservation, making use of them, meanwhile, for the instruction of the public. I should be sorry to lose all right to them, because I hope they may have another final destination. I do not despair of seeing the different parts of Switzerland united at some future day by a closer tie, and in case of such a union a truly Helvetic university would become a necessity; then, my aim would be to make my collection the basis of that which they would be obliged to found for their courses of lectures. It is really a shame that Switzerland, richer and more extensive than 
many a small kingdom, should have no university, when some states of not half its size have even two; for instance, the grand duchy of Baden, one of whose universities, that of Heidelberg, ranks among the first in all Germany. If ever I attain a position allowing me so to do, I shall make every effort in my power to procure for my country the greatest of benefits: namely, that of an intellectual unity, which can arise only from a high degree of civilization, and from the radiation of knowledge from one central point.

I, too, have considered the question about Dinkel, and if, when I have finished my work here, my position is not changed, and I have no definite prospect, such as would justify me in keeping him with me, - well! then we must part! I have long been preparing myself for this, by employing him only upon what is indispensable to the publication of my first numbers, hoping that these may procure me the means of paying for such illustrations as I shall further need. As my justification for having engaged him in the first instance, and continued this expense till now, I can truly say that it is in a great degree through his drawings that M. Cuvier has been able to judge of my work, and so has been led to vor $\mathrm{I}$. 
make a surrender of all his materials in my favor. I foresaw clearly that this was my only chance of competing with him, and it was not without reason that I insisted so strongly on having Dinkel with me in passing through Strasbourg and subsequently at Carlsruhe. Had I not done so, M. Cuvier might still be in advance of me. Now my mind is at rest on this score; I have already written you all about his kindness in offering me the work. Could I only be equally fortunate in its publication!

M. Cuvier urges me strongly to present my book to the Academy, in order to obtain a report upon its contents. I must first finish it, however, and the task is not a light one. For this reason, above all, I regret my want of means; but for that I could have the drawings made at once, and the Academy report, considered as a recommendation, would certainly help on the publication greatly. But in this respect I have long been straitened; Auguste knows that I had at Munich an artist who was to complete what I had left there for execution, and that I stopped his work on leaving Concise. If the stagnation of the book-trade continues I shall, perhaps, be forced to give up Dinkel also; for if I cannot be- 
gin the publication, which will, I hope, bring me some return, I must cease to accumulate material in advance. Should business revive soon, however, I may yet have the pleasure of seeing all completed before I leave Paris.

I think I forgot to mention the arrival of Braun six weeks after me. I had a double pleasure in his coming, for he brought with him his younger brother, a charming fellow, and a distinguished pupil of the polytechnic school of Carlsruhe. He means to be a mining engineer, and comes to study such collections at Paris as are connected with this branch. You cannot imagine what happiness and comfort I have in my relations with Alexander; he is so good, so cultivated and highminded, that his friendship is a real blessing to me. We both feel very much our separation from the elder Schimper, who, spite of his great desire to join us at Carlsruhe and accompany us to Paris, was not able to leave Munich.

P. S. My love to Auguste. To-day (Sunday) I went again to see M. Humboldt about Auguste's ${ }^{1}$ plan, but did not find him.

Then follow several pages, addressed to his 2 Concerning a business undertaking in Mexico. 
father, in answer to the request contained in one of his last letters that Louis would tell him as much as he thinks he can understand of his work. There is something touching in this little lesson given by the son to the father, as showing with what delight Louis responded to the least touch of parental affection respecting his favorite studies, so long looked upon at home with a certain doubt and suspicion. The whole letter is not given here, as it is simply an elementary treatise on geology; but the close is not without interest as relating to the special investigations on which he was now employed.

"The aim of our researches upon fossil animals is to ascertain what beings have lived at each one of these (geological) epochs of creation, and to trace their characters and their relations with those now living; in one word, to make them live again in our thought. It is especially the fishes that I try to restore for the eyes of the curious, by showing them which ones have lived in each epoch, what were their forms, and, if possible, by drawing some conclusions as to their probable modes of life. You will better understand the difficulty of my work when I tell you that in many species I have only a single tooth, a 
scale, a spine, as my guide in the reconstruction of all these characters, although sometimes we are fortunate enough to find species with the fins and the skeletons complete. . . .

"I ask pardon if I have tired you with my long talk, but you know how pleasant it is to ramble on about what interests us, and the pleasure of being questioned by you upon subjects of this kind has been such a rare one for me, that I have wished to present the matter in its full light, that you may understand the zeal and the enthusiasm which such researches can excite."

To this period belongs a curious dream mentioned by Agassiz in his work on the fossil fishes. ${ }^{1}$ It is interesting both as a psychological fact and as showing how, sleeping and waking, his work was ever present with him. He had been for two weeks striving to decipher the somewhat obscure impression of a fossil fish on the stone slab in which it was preserved. Weary and perplexed he put his work aside at last, and tried to dismiss it from his mind. Shortly after, he waked one night persuaded that while asleep he had seen his fish with all the missing features perfectly restored.

1 Recherches sur les Poissons Fossiles. Cyclopoma spinosum Agassiz. Vol. iv. tab. 1, pp. 20, 21. 
But when he tried to hold and make fast the image, it escaped him. Nevertheless, he went early to the Jardin des Plantes, thinking that on looking anew at the impression he should see something which would put him on the track of his vision. In vain, - the blurred record was as blank as ever. The next night he saw the fish again, but with no more satisfactory result. When he awoke it disappeared from his memory as before. Hoping that the same experience might be repeated, on the third night he placed a pencil and paper beside his bed before going to sleep. Accordingly toward morning the fish reappeared in his dream, confusedly at first, but at last with such distinctness that he had no longer any doubt as to its zoölogical characters. Still half dreaming, in perfect darkness, he traced these characters on the sheet of paper at the bedside. In the morning he was surprised to see in his nocturnal sketch features which he thought it impossible the fossil itself should reveal. He hastened to the Jardin des Plantes, and, with his drawing as a guide, succeeded in chiseling away the surface of the stone under which portions of the fish proved to be hidden. When wholly exposed it corresponded with his dream and his drawing, and he suc- 
ceeded in classifying it with ease. $\mathrm{He}$ often spoke of this as a good illustration of the well-known fact, that when the body is at rest the tired brain will do the work it refused before. 


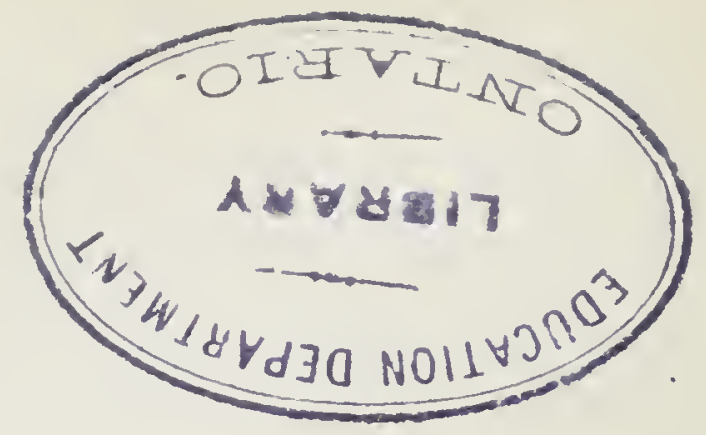

\section{CHAPTER VI.}

1832 : ЖTT. 25.

Unexpected Relief from Difficulties. - Correspondence with Humboldt. - Excursion to the Coast of Normandy. - First Sight of the Sea. - Correspondence concerning Professorship at Neuchâtel. - Birthday Fête. - Invitation to Chair of Natural History at Neuchâtel. - Acceptance. - Letter to Humboldt.

Agassiz was not called upon to make the sacrifice of giving up his artist and leaving Paris, although he was, or at least thought himself, prepared for it. The darkest hour is before the dawn, and the letter next given announces an unexpected relief from pressing distress and anxiety.

TO HIS FATHER AND MOTHER.

PARIS, March, 1832.

... I am still so agitated and so surprised at what has just happened that I scarcely believe what my eyes tell me.

I mentioned in a postscript to my last letter that I had called yesterday on M. de Hum- 
boldt, whom I had not seen for a long time, in order to speak to him concerning Auguste's affair, but that I did not find him. In former visits I had spoken to him about my position, and told him that I did not well know what course to take with my publisher. He offered to write to him, and did so more than two months ago. Thus far, neither he nor I have had any answer. This morning, just as I was going out, a letter came from M. de Humboldt, who writes me that he is very uneasy at receiving no reply from Cotta, that he fears lest the uncertainty and anxiety of mind resulting from this may be injurious to my work, and begs me to accept the inclosed credit of a thousand francs..... Oh! if my mother would forget for one moment that this is the celebrated M. de Humboldt, and find courage to write him only a few lines, how grateful I should be to her. I think it would come better from her than from papa, who would do it more correctly, no doubt, but perhaps not quite as I should like. Humboldt is so good, so indulgent, that you should not hesitate, dear mother, to write him a few lines. He Iives Rue du Colombier, No. 22; address, quite simply, M. de Humboldt. . . . 
In the agitation of the moment the letter was not even signed.

The following note from Humboldt to Mme. Agassiz, kept by her as a precious possession, shows that in answer to her son's appeal his mother took her courage, as the French saying is, "with both hands," and wrote as she was desired.

FROM HUMBOLDT TO MME. AGASSIZ.

PARIS, April 11, 1832.

I should scold your son, Madame, for having spoken to you of the slight mark of interest I have been able to show him; and yet, how can I complain of a letter so touching, so noble in sentiment, as the one I have just received from your hand. Accept my warmest thanks for it. How happy you are to have a son so distinguished by his talents, by the variety and solidity of his acquirements, and, withal, as modest as if he knew nothing, in these days, too, when youth is generally characterized by a cold and scornful amourpropre. One might well despair of the world if a person like your son, with information so substantial and manners so sweet and prepossessing, should fail to make his way. I approve highly the Neuchâtel plan, and hope, 
in case of need, to contribute to its success. One must aim at a settled position in life.

Pray excuse, Madame, the brevity of these lines, and accept the assurance of my respectful regard.

Humboldt.

The letter which lifted such a load of care from Louis and his parents was as follows :-

HUMBOLDT TO LOUIS AGASSIZ.

PARIS, March 27, 1832.

I am very uneasy, my dearest M. Agassiz, at being still without any letter from Cotta. Has he been prevented from writing by business, or illness perhaps? You know how tardy he always is about writing. Yesterday (Monday) I wrote him earnestly again concerning your affair (an undertaking of such moment for science), and urged upon him the issuing of the fossil and fresh-water fishes in alternate numbers. In the mean time, I fear that the protracted delay may weigh heavily on you and your friends. A man so laborious, so gifted, and so deserving of affection as you are should not be left in a position where lack of serenity disturbs his power of work. You will then surely pardon my friendly goodwill toward you, my dear M. Agassiz, if I en- 
treat you to make use of the accompanying small credit. You would do more for me I am sure. Consider it an advance which need not be paid for years, and which I will gladly increase when I go away or even earlier. It would pain me deeply should the urgency of my request made in the closest confidence, in short, a transaction as between two friends of unequal age, - be disagreeable to you. I should wish to be pleasantly remembered by a young man of your character.

Yours, with the most affectionate respect,

\section{Alexander Humboldt.}

With this letter was found the following note of acknowledgment, scrawled in almost illegible pencil marks. Whether sent exactly as it stands or not, it is evidently the first outburst of Agassiz's gratitude.

My benefactor and friend, - it is too much; I cannot find words to tell you how deeply your letter of to-day has moved me. I have just been at your house that I might thank you in person with all my heart; but now I must wait to do so until I have the good fortune to meet you. At what a moment does your help come to me! I inclose a letter from 
my dear mother that you may understand my whole position. My parents will now readily consent that I should devote myself entirely to science, and I am freed from the distressing thought that I may be acting contrary to their wishes and their will. But they have not the means to help me, and had proposed that I should return to Switzerland and give lessons either in Geneva or Lausanne. I had already resolved to follow this suggestion in the course of next summer, and had also decided to part with Mr. Dinkel, my faithful companion, as soon as he should have finished the most indispensable drawings of the fossils on which he is now engaged here. I meant to tell you of this on Sunday, and now to-day comes your letter. Imagine what must have been my feeling, after having resolved on renouncing what till now had seemed to me noblest and most desirable in life, to find myself unexpectedly rescued by a kind, helpful hand, and to have again the hope of devoting my whole powers to science, - you can judge of the state into which your letter has thrown me. . . .

Soon after this event Agassiz made a short excursion with Braun and Dinkel to the coast of Normandy; worth noting, because he now 
saw the sea for the first time. He wrote home: "For five days we skirted the coast from Havre to Dieppe; at last I have looked upon the sea and its riches. From this excursion of a few days, which I had almost despaired of making, I bring back new ideas, more comprehensive views, and a more accurate knowledge of the great phenomena presented by the ocean in its vast expanse."

Meanwhile the hope he had always entertained of finding a professorship of natural history in his own country was ripening into a definite project. His first letter on this subject to M. Louis Coulon, himself a wellknown naturalist, and afterward one of his warmest friends in Neuchâtel, must have been written just before he received from Humboldt the note of the same date, which extricated him from his pecuniary embarrassment.

AGASSIZ TO LOUIS COULON.

PARIs, March 27, 1832.

... When I had the pleasure of seeing you last summer I several times expressed my strong desire to establish myself near you, and my intention of taking some steps toward obtaining the professorship of natural history to be founded in your Lyceum. The matter 
must be more advanced now than it was last year, and you would oblige me greatly by giving me some information concerning it. I have spoken of my project to M. de Humboldt, whom I often see, and who kindly interests himself about my prospects and helps me with his advice. He thinks that under the circumstances, and especially in my position, measures should be taken in advance. There is another point of great importance for me about which I wished also to speak to you. Though you have seen but a small part of it, you nevertheless know that in my different journeys, partly through my relations with other naturalists, partly by exchange, I have made a very fair collection of natural history, especially rich in just those classes which are less fully represented in your museum. My collection might, therefore, fill the gaps in that of the city of Neuchâtel, and make the latter more than adequate for the illustration of a full course of natural history. Should an increase of your zoölogical collection make part of your plans for the Lyceum, I venture to believe that mine would fully answer your purpose. In that case I would offer it to you, since the expense of arranging it, the rent of a room in which to keep it, and, in short, its 
support in general, is beyond my means. I must find some way of relieving myself from this burden, although it will be hard to part with these companions of my study, upon which I have based almost all my investigations. I have spoken of this also to $\mathrm{M}$. de Humboldt, who is good enough to show an interest in the matter, and will even take all necessary steps with the government to facilitate this purchase. You would render me the greatest service by giving me your directions about all this, and especially by telling me: 1. On whom the nomination to the professorship depends? 2. With whom the purchase of the collection would rest? 3. What you think I should do with reference to both? Of course you will easily understand that I cannot give up my collections except under the condition that I should be allowed the free use of them. . . .

The answer was not only courteous, but kind, although some time elapsed before the final arrangements were made. Meanwhile the following letter shows us the doubts and temptations which for a moment embarrassed Agassiz in his decision. The death of Cuvier had intervened. 
AGASSIZ TO HUMBOLDT.

Paris, May, 1832.

-. I would not write you until I had definite news from Neuchâtel. Two days ago I received a very delightiful letter from $M$. Coulon, which I hasten to share with you. I will not copy the whole, but extract the essential part. He tells me that he has proposed to the Board of Education the establishment of a professorship of natural history, to be offered to me. The proposition met with a cordial hearing. The need of such a professorship was unanimously recognized, but the President explained that neither would the condition of the treasury allow its establishment in the present year, nor could the proposition be brought before the Council of State until the opening of the new Lyceum.

Monsieur Coulon was commissioned to thank me, and to request me in the name of the board to keep the place in mind; should I prefer it, however, he doubts not that whatever the city could not do might be made good by subscription before next autumn, in which case I could enter upon office at once. He requests a prompt answer in order that he may make all needful preparations. Only too VOL. I. 
gladly would I have consulted you about various propositions made to me here in the last few days, and have submitted my course to your approval, had it not been that here, as in Neuchâtel, a prompt answer was urged. Although guided rather by instinct than by anything else, I think, nevertheless, that I have chosen rightly. In such moments, when one cannot see far enough in advance to form an accurate judgment upon deliberation, feeling is, after all, the best adviser; that inner impulse, which is a safe guide if other considerations do not confuse the judgment. This says to me, "Go to Neuchâtel; do not stay in Paris." But I speak in riddles; I must explain myself more clearly. Last Monday Levrault sent for me in order to propose that Valenciennes and I should jointly undertake the publication of the Cuvierian fishes. . . . I was to give a positive answer this week. I have carefully considered it, and have decided that an unconditional engagement would lead me away from my nearest aim, and from what I look upon as the task of my life. The already published volumes of the System of Ichthyology lie too far from the road on which I intend to pursue my researches. Finally, it seems to me that in a quiet retired place 
like Neuchâtel, whatever may be growing up within me will have a more independent and individual development than in this restless Paris, where obstacles or difficulties may not perhaps divert me from a given purpose, but may disturb or delay its accomplishment. I will therefore so shape my answer to Levrault as to undertake only single portions of the work, the choice of these, on account of my interest in the fossil and the fresh-water fishes, being allowed me, with the understanding, also, that I should be permitted to have these collections in Switzerland and work them up there. From Paris, also, it would not be so easy to transfer myself to Germany, whereas I could consider Neuchâtel as a provisional position from which I might be called to a German university. ...

In the mean time, while waiting hopefully the result of his negotiations with Neuchâtel, Agassiz had organized with his friends, the two Brauns, a bachelor life very like the one he and Alexander had led with their classmates in Munich. The little hotel where they lodged had filled up with young German doctors, who had come to visit the hospitals in Paris and study the cholera. Some of these young men 
had been their fellow-students at the university, and at their request Agassiz and Braun resumed the practice of giving private lectures on zoölogy and botany, the whole being conducted in the most informal manner, admitting absolute freedom of discussion, as among intimate companions of the same age. Such an interchange naturally led to very genial relations between the amateur professors and their class, and on the eve of Agassiz's birthday (28th of May) his usual audience prepared for him a very pleasant surprise. Returning from a walk after dusk he found Braun in his room. Continuing his stroll within four walls, he and his friend paced the floor together in earnest talk, when, at a signal, Braun suddenly drew him to the window, threw it open, and on the pavement below stood their companions, singing a part song, composed in honor of Agassiz. Deeply moved, he withdrew from the window in time to receive them as they trooped up the stairway to offer their good wishes. They presently led the way to another room which they had dressed with flowers, Agassiz's name, among other decorations, being braided in roses beneath two federal flags crossed on the wall. Here supper was laid, and the rest of the evening passed gayly with songs and 
toasts, not only for the hero of the feast and for friends far and near, but for the progress of science, the liberty of the people, and the independence of nations. There could be no meeting of ardent young Germans and Swiss in those days without some mingling of patriotic aspirations with the sentiment of the hour.

The friendly correspondence between Agassiz and M. Coulon regarding the professorship at Neuchâtel was now rapidly bringing the matter to a happy conclusion.

\section{AGASSIZ TO LOUIS COULON.}

Paris, June 4, 1832.

I have received your kind letter with great pleasure and hasten to reply. What you write gives me the more satisfaction because it opens to me in the near future the hope of establishing myself in your neighborhood and devoting to my country the fruits of my labor. It is true, as you suppose, that the death of M. Cuvier has sensibly changed my position; indeed, I have already been asked to continue his work on fishes in connection with M. Valenciennes, who made me this proposition the day after your letter reached me. The conditions offered me are, indeed, very tempting, 
but I am too little French by character, and too anxious to live in Switzerland, not to prefer the place you can offer me, however small the appointments, if they do but keep me above actual embarrassment. I say thus much only in order to answer that clause in your letter where you touch upon this question. I would add that I leave the field quite free in this respect, and that I am yours without reserve, if, indeed, within the fortnight, the urgency of the Parisians does not carry the day, or, rather, as soon as I write you that I have been able finally to withdraw. You easily understand that I cannot bluntly decline offers which seem to those who make them so brilliant. But I shall hold out against them to the utmost. My course with reference to my own publications will have shown you that I do not care for a lucrative position from personal interest; that, on the contrary, I should always be ready to use such means as I may have at my disposition for the advancement of the institution confided to my care.

My work will still detain me for four or five months at Paris, - my time being after that completely at my disposal. The period at which I should like to begin my lectures is therefore very near, and I think if your people 
are favorably disposed toward the creation of a new professorship we must not let them grow cold. But you have shown me so much kindness that I may well leave to your care, in concert with your friends, the decision of this point; the more so since you are willing to take charge of my interests, until you see the success of what you are pleased to look upon as an advantage to your institution, while for me it is the realization of a sincere desire to do what I can for the advancement of science, and the instruction of our youth. . .

The next letter from M. Coulon (June 18, 1832) announces that the sum of eighty louis having been guaranteed for three years, chiefly by private individuals, but partly also by the city, they were now able to offer a chair of natural history at once to their young countryman. In conclusion, he adds:-

"I can easily understand that the brilliant offers made you in Paris strongly counterbalance a poor little professorship of natural history at Neuchâtel, and may well cause you to hesitate; especially since your scientific career there is so well begun. On the other hand, you cannot doubt our pleasure in the prospect of having you at Neuchâtel, not only 
because of the friendship felt for you by many persons here, but also on account of the lustre which a chair of natural history so filled would shed upon our institution. Of this our subscribers are well aware, and it accounts for the rapid filling of the list. I am very anxious, as are all these gentlemen, to know your decision, and beg you therefore to let us hear from you as soon as possible."

A letter from Humboldt to M. Coulon, about this time, is an earnest of his watchful care over the interests of Agassiz.

\section{HUMBOLDT TO LOUIS COULON.}

Potsdam, July 25, 1832.

... I do not write to ask a favor, but only to express my warm gratitude for your noble and generous dealings with the young savant, M. Agassiz, who is well worthy your encouragement and the protection of your government. $\mathrm{He}$ is distinguished by his talents, by the variety and substantial character of his attainments, and by that which has a special value in these troubled times, his natural sweetness of disposition.

Through our common friend, M. von Buch, I have known for many years that you study natural history with a success equal to your 
zeal, and that you have brought together fine collections, which you place at the disposal of others with a noble liberality. It gratifies me to see your kindness toward a young man to whom I am so warmly attached; whom the illustrious Cuvier, also, whose loss we must ever deplore, would have recommended with the same heartiness, for his faith, like mine, was based on those admirable works of Agassiz which are now nearly completed. . . .

I have strongly advised M. Agassiz not to accept the offers made to him at Paris since M. Cuvier's death, and his decision has anticipated my advice. How happy it would be for him, and for the completion of the excellent works on which he is engaged, could he this very year be established on the shores of your lake! I have no doubt that he will receive the powerful protection of your worthy governor, to whom I shall repeat my requests, and who honors me, as well as my brother, with a friendship I warmly appreciate. M. von Buch also has promised me, before leaving Berlin for Bonn and Vienna, to add his entreaty to mine. . . He is almost as much interested as myself in M. Agassiz and his work on fossil fishes, the most important ever undertaken, and equally exact in its relation 
to zoölogical characters and to geological deposits. . . .

The next letter from Agassiz to his influential friend is written after his final acceptance of the Neuchâtel professorship.

AGASSIZ TO HUMBOLDT.

PARIS, July, 1832.

... I would most gladly have answered your delightful letter at once, and have told you how smoothly all has gone at Neuchâtel. Your letters to M. de Coulon and to General von Pfuiel have wrought marvels; but they are now inclined to look upon me there as a wonder from the deep, ${ }^{1}$ and I must exert myself to the utmost lest my actual presence should give the lie to fame. It is all right. I shall be the less likely to relax in devotion to my work.

The real reason of my silence has been that I was unwilling to acknowledge so many evidences of efficient sympathy and friendly encouragement by an empty letter. I wished especially to share with you the final result of my investigations on the fossil fishes, and for that purpose it was necessary to revise my

1 Ein blaues Meerwunder. 
manuscripts and take an account of my tables in order to condense the whole in a few phrases. I have already told you that the investigation of the living fishes had suggested to me a new classification, in which families as at present circumscribed respectively received new, and to my thinking more natural positions, based upon other considerations than those hitherto brought forward. I did not at first lay any special stress on my classification. ... My object was only to utilize certain structural characters which frequently recur among fossil forms, and which might therefore enable me to determine remains hitherto considered of little value.... Absorbed in the special investigation, I paid no heed to the edifice which was meanwhile unconsciously building itself up. Having however completed the comparison of the fossil species in Paris, I wanted, for the sake of an easy revision of the same, to make a list according to their succession in geological formations, with a view of determining the characteristics more exactly and bringing them by their enumeration into bolder relief. What was my joy and surprise to find that the simplest enumeration of the fossil fishes according to their geological succession was also a complete statement 
of the natural relations of the families among themselves; that one might therefore read the genetic development of the whole class in the history of creation, the representation of the genera and species in the several families being therein determined; in one word, that the genetic succession of the fishes corresponds perfectly with their zoölogical classification, and with just that classification proposed by me. The question therefore in characterizing formations is no longer that of the numerical preponderance of certain genera and species, but of distinct structural relations, carried through all these formations according to a definite direction, following each other in an appointed order, and recognizable in the organisms as they are brought forth. ... If my conclusions are not overturned or modified through some later discovery, they will form a new basis for the study of fossils. Should you communicate my discovery to others I shall be especially pleased, because it may be long before I can begin to publish it myself, and many may be interested in it. This seems to me the most important of my results, though I have also, partly from perfect specimens, partly from fragments, identified some five hundred extinct species, and 
more than fifty extinct genera, beside reëstablishing three families no longer represented.

Cotta has written me in very polite terms that he could not undertake anything new at present; he would rather pay, without regard to profit, for what has been done thus far, and lets me have fifteen hundred francs. This makes it possible for me to leave Dinkel in Paris to complete the drawings. Although it often seems to me hard, I must reconcile myself to the thought of leaving investigations which are actually completed, locked up in my desk. ... 


\section{CHAPTER VII.}

$1832-1834$ : ET. $25-27$.

Enters upon his Professorship at Neuchâtel. - First Lecture. - Success as a Teacher. - Love of Teaching. - Influence upon the Scientific Life of Neuchâtel. — Proposal from University of Heidelberg. - Proposal declined. - Threatened Blindness. - Correspondence with Humboldt. - Marriage. - Invitation from Charpentier. - Invitation to visit England. - Wollaston Prize. - First Number of "Poissons Fossiles." - Review of the Work.

The following autumn Agassiz assumed the duties of his professorship at Neuchâtel. His opening lecture "Upon the Relations between the different branches of Natural History and the then prevailing tendencies of all the Sciences" was given on the 12th of November, 1832, at the Hotel de Ville. Judged by the impression made upon the listeners as recorded at the time, this introductory discourse must have been characterized by the same broad spirit of generalization which marked Agassiz's later teaching. Facts in his hands fell into their orderly relation as parts of a connected whole, and were never presented 
merely as special or isolated phenomena. From the beginning his success as an instructor was undoubted. He had, indeed, now entered upon the occupation which was to be from youth to old age the delight of his life. Teaching was a passion with him, and his power over his pupils might be measured by his own enthusiasm. $\mathrm{He}$ was intellectually, as well as socially, a democrat, in the best sense. He delighted to scatter broadcast the highest results of thought and research, and to adapt them even to the youngest and most

- uninformed minds. In his later American travels he would talk of glacial phenomena to the driver of a country stage-coach among the mountains, or to some workman, splitting rock at the road-side, with as much earnestness as if he had been discussing problems with a brother geologist; he would take the - common fisherman into his scientific confidence, telling him the intimate secrets of fishstructure or fish-embryology, till the man in his turn grew enthusiastic, and began to pour out information from the stores of his own rough and untaught habits of observation. Agassiz's general faith in the susceptibility of the popular intelligence, however untrained, to the highest truths of nature, was 
contagious, and he created or developed that in which he believed.

In Neuchâtel the presence of the young professor was felt at once as a new and stimulating influence. The little town suddenly became a centre of scientific activity. A society for the pursuit of the natural sciences, of which he was the first secretary, sprang into life. The scientific collections, which had already attained, under the care of M. Louis Coulon, considerable value, presently assumed the character and proportions of a well-ordered museum. In M. Coulon Agassiz found a generous friend and a scientific colleague who sympathized with his noblest aspirations, and was ever ready to sustain all his efforts in behalf of scientific progress. Together they worked in arranging, enlarging, and building up a museum of natural history which soon became known as one of the best local institutions of the kind in Europe.

Beside his classes at the gymnasium, Agassiz collected about him, by invitation, a small audience of friends and neighbors, to whom he lectured during the winter on botany, on zoölogy, on the philosophy of nature. The instruction was of the most familiar and informal character, and was continued in later 
years for his own children and the children of his friends. In the latter case the subjects were chiefly geology and geography in connection with botany, and in favorable weather the lessons were usually given in the open air. One can easily imagine what joy it must have been for a party of little playmates, boys and girls, to be taken out for long walks in the country over the hills about Neuchâtel, and especially to Chaumont, the mountain which rises behind it, and thus to have their lessons, for which the facts and scenes about them furnished subject and illustration, combined with pleasant rambles. From some high ground affording a wide panoramic view Agassiz would explain to them the formation of lakes, islands, rivers, springs, water-sheds, hills, and valleys. He always insisted that physical geography could be better taught to children in the vicinity of their own homes than by books or maps, or even globes. Nor did he think a varied landscape essential to such instruction. Undulations of the ground, some contrast of hill and plain, some sheet of water with the streams that feed it, some ridge of rocky soil acting as a water-shed, may be found everywhere, and the relation of facts shown perhaps as well on a small as on a large scale. 
When it was impossible to give the lessons out of doors, the children were gathered around a large table, where each one had before him or her the specimens of the day, sometimes stones and fossils, sometimes flowers, fruits, or dried plants. To each child in succession was explained separately what had first been told to all collectively. When the talk was of tropical or distant countries pains were taken to procure characteristic specimens, and the children were introduced to dates, bananas, cocoa-nuts, and other fruits, not easily to be obtained in those days in a small inland town. They, of course, concluded the lesson by eating the specimens, a practical illustration which they greatly enjoyed. A very large wooden globe, on the surface of which the various features of the earth as they came up for discussion could be shown, served to make them more clear and vivid. The children took their own share in the instruction, and were themselves made to point out and describe that which had just been explained to them. They took home their collections, and as a preparation for the next lesson were often called upon to classify and describe some unusual specimen by their own unaided efforts. There was no tedium in the class. Agassiz's 
lively, clear, and attractive method of teaching awakened their own powers of observation in his little pupils, and to some at least opened permanent sources of enjoyment.

His instructions to his older pupils were based on the same methods, and were no less acceptable to them than to the children. In winter his professional courses to the students were chiefly upon zoölogy and kindred topics; in the summer he taught them botany and geology, availing himself of the fine days for excursions and practical instruction in the field. Professor Louis Favre, speaking of these excursions, which led them sometimes into the gorges of the Seyon, sometimes into the forests of Chaumont, says: "They were fête days for the young people, who found in their professor an active companion, full of spirits, vigor, and gayety, whose enthusiasm kindled in them the sacred fire of science."

It was not long before his growing reputation brought him invitations from elsewhere. One of the first of these was from Heidelberg.

PROFESSOR TIEDEMANN TO LOUIS AGASSIZ.

Heideliberg, December 4, 1832.

. . L Last autumn, when I had the pleasure of meeting you in Carlsruhe, I proposed to 
you to give some lectures on Natural History at this university. Professor Leuckart, who till now represented zoölogy here, is called to Freiburg, and you would therefore be the only teacher in that department. The university being so frequented, a numerous audience may be counted upon. The zoölogical collection, by no means an insignificant one, is open to your use. Professor Leuckart received a salary of five hundred florins. This is now unappropriated, and I do not doubt that the government, conformably to the proposition of the medical faculty, would give you the appointment on the same terms. By your knowledge you are prepared for the work of an able academical teacher. My advice is, therefore, that you should not bind yourself to any lyceum or gymnasium, as a permanent position; such a place would not suit a cultivated scientific man, nor does it offer a field for an accomplished scholar. Consider carefully, therefore, a question which concerns the efficiency of your life, and give me the result of your deliberation as soon as possible. Should it be favorable to the acceptance of my proposition, I hope you will find yourself here at Easter as full professor, with a salary of five hundred florins, and a fitting field of ac- 
tivity for your knowledge. The fees for lectures and literary work might bring you in an additional fifteen hundred gulden yearly. If you accede to this offer send me your inaugural dissertation, and make me acquainted with your literary work, that I may take the necessary steps with the Curatorio. Consider this proposition as a proof of my high appreciation of your literary efforts and of my regard for you personally.

Agassiz's next letter to Humboldt is to consult him with respect to the call from Heidelberg, while it is also full of pleasure at the warm welcome extended to him in Neuchâtel.

AGASSIZ TO HUMBOLDT.

December, 1832.

... At last I am in Neuchâtel, having, indeed, begun my lectures some weeks ago. I have been received in a way $I$ could never have anticipated, and which can only be due to your good-will on my behalf and your friendly recommendation. You have my warmest thanks for the trouble you have taken about me, and for your continued sympathy. Let me show you by my work in the years to come, rather than by words, that I am in earnest 
about science, and that my spirit is not irresponsive to a noble encouragement such as you have given me.

You will have received my letter from Carlsruhe. Could I only tell you all that I have since thought and observed about the history of our earth's development, the succession of the animal populations, and their genetic classification! It cannot easily be compressed within letter limits; I will, nevertheless, attempt it when my lectures make less urgent claim upon me, and my eyes are less fatigued. I should defer writing till then were it not that to-day I have something of at least outside interest to announce. It concerns the inclosed letter received to-day. (The offer of a professorship at Heidelberg.) Should you think that I need not take it into consideration, and you have no time to answer me, let me know your opinion by your silence. I will tell you the reasons which would induce me to remain for the present in Neuchâtel, and I think you will approve them. First, as my lectures do not claim a great part of my time I shall have the more to bestow on other work; add to this the position of Neuchâtel, so favorable for observations such as I propose making on the history of development in several classes 
of animals; then the hope of freeing myself from the burden of my collections; and next, the quiet of my life here with reference to my somewhat overstrained health. Beside my wish to remain, these favorable circumstances furnish a powerful motive, and then I am satisfied that people here would assist me with the greatest readiness should my publications not succeed otherwise. As to the publication of my fishes, I can, after all, better direct the lithographing of the plates here. I have just written to Cotta concerning this, proposing also that he should advance the cost of the lithographs. I shall attend to it all carefully, and be content for the present with my small means. From the gradual sale he can, little by little, repay my expenses, and I shall ask no profit until the success of the work warrants it. I await his answer. This proposal seems to me the best and the most likely to advance the publication of this work.

Since I arrived here some scientific efforts have been made with the help of M. Coulon. We have already founded a society of Natural History, ${ }^{1}$ and I hope, should you make your promised visit next year, you will find this germ between foliage and flower at

1 Société des Sciences Naturelles de Neuchâtel. 
least, though perhaps not yet ripened into seed. . . .

M. Coulon told me the day before yesterday that he had spoken with M. de Montmollin, the Treasurer, who would write to M. Ancillon concerning the purchase of my collection. ... Will you have the kindness, when occasion offers, to say a word to M. Ancillon about it? . . . Not only would this collection be of the greatest value to the museum here, but its sale would also advance my farther investigations. With the sum of eighty louis, which is all that is subscribed for my professorship, I cannot continue them on any large scale.

I await now with anxiety Cotta's answer to my last proposition; but whatever it be, I shall begin the lithographing of the plates immediately after the New Year, as they must be carried on under my own eye and direction. This I can well do since my uncle, Dr. Mayor in Lausanne, gives me fifty louis toward it, the amount of one year's pay to Weber, my former lithographer in Munich. I have therefore written him to come, and expect him after New Year. With my salary I can also henceforth keep Dinkel, who is now in Paris, drawing the last fossils which I described. . . . 
No answer to this letter has been found beyond such as is implied in the following to M. Coulon.

HUMBOLDT TO M. COULON, FUS.

Berlin, January 21, 1833.

.. . It gives me great pleasure to acknowledge the flattering welcome offered by you and your fellow-citizens to M. Agassiz, who stands so high in science, and whose intellectual qualities are enhanced by his amiable character. They write me from Heidelberg that they intend the place of M. Leuckart in zoölogy for my young friend. The choice is proposed by M. Tiedemann, and certainly nothing could be more honorable to M. Agassiz. Nevertheless, I hope that he will refuse it. $\mathrm{He}$ should remain for some years in your country, where a generous encouragement facilitates the publication of his work, which is of equal importance to zoölogy and geology.

I have spoken with M. Ancillon, and have left with him an official notice respecting the purchase of the Agassiz collection. The difficulty will be found, as in all human affairs, in the prose of life, in money. M. Ancillon writes me this morning: "Your paper in favor of M. Agassiz is a scientific letter of credit 
which we shall try to honor. The acquisition of a superior man and a superior collection at the same time would be a double conquest for the principality of Neuchâtel. I have requested a report from the Council of State on the means of accomplishing this, and I hope that private individuals may do something toward it." Thus you see the affair is at least on the right road. I do not think, however, that the royal treasury will give at present more than a thousand Prussian crowns toward it. ...

Regarding the invitation to Heidelberg, Agassiz's decision was already made. A letter to his brother toward the close of December mentions that he is offered a professorship at the University of Heidelberg, but that, although his answer has not actually gone, he has resolved to decline it; adding that the larger salary is counterbalanced in his mind by the hope of selling his collection at Neuchâtel, and thus freeing himself from a heavy burden.

Agassiz was now threatened with a great misfortune. Already, in Paris, his eyes had begun to suffer from the strain of microscopic work. They now became seriously impaired; 
and for some months he was obliged to abate his activity, and to refrain even from writing a letter. During this time, while he was shut up in a darkened room, he practiced the study of fossils by touch alone, using even the tip of the tongue to feel out the impression, when the fingers were not sufficiently sensitive. $\mathrm{He}$ said he was sure at the time that he could bring himself in this way to such delicacy of touch that the loss of sight would not oblige him to abandon his work. After some months his eyes improved, and though at times threatened with a return of the same malady, he was able, throughout life, to use his eyes more uninterruptedly than most persons. His lectures, always delivered extemporaneously, do not seem to have been suspended for any length of time.

The following letter from Agassiz to Humboldt is taken from a rough and incomplete draught, which was evidently put aside (perhaps on account of the trouble in his eyes), and only completed in the following May. Although imperfect, it explains Humboldt's answer, which is not only interesting in itself, but throws light on Agassiz's work at this period. 
AGASSIZ TO HUMBOLDT.

NeuChâtel, January 27, 1833.

... A thousand thanks for your last most welcome letter. I can hardly tell you what pleasure it gave me, or how I am cheered and stimulated to new activity by intercourse with you on so intimate a footing. Since I wrote you, some things have become more clear to me, as, for instance, my purpose of publishing the "Fossil Fishes" here. Certain doubts remain in my mind, however, about which, as well as about other matters, I would ask your advice. Now that Cotta is dead, I cannot wait till I have made an arrangement with his successor. I therefore allow the "Fresh-Water Fishes" to lie by and drive on the others. Upon careful examination I have found, to my astonishment, that all necessary means for the publication of such a work are to be had here: two good lithographers and two printing establishments, both of which have excellent type. I have sent for Weber to engrave the plates, or draw them on stone; he will be here at the end of the month. Then I shall begin at once, and hope in May to send out the first number. The great difficulty remains now in the distribution of the numbers, and in finding a suff- 
cient sale so that they may follow each other with regularity. I think it better to begin the publication as a whole than to send out an abridgment in advance. The species can be characterized only by good illustrations. A summary always requires farther demonstration, whereas, if I give the plates at once I can shorten the text and present the general results as an introduction to the first number. With twelve numbers, of twenty plates each, followed by about ten pages of text, I can tell all that I have to say. The cost of one hundred and fifty copies printed here would, according to careful inquiry, be covered by seventy subscriptions if the price were put at one louis-d'or the number.

Now comes the question whether I should print more than one hundred and fifty copies. On account of the expense I shall not preserve the stones. For the distribution of the copies and the collecting of the money could you, perhaps, recommend me to some house in Berlin or Leipzig, who would take the work for sale in Germany on commission under reasonable conditions? For England, I wrote yesterday to Lyell, and to-morrow I shall write to Levrault and Bossange.

Both the magistrates and private individ- 
uals here are now much interested in public instruction, and I am satisfied that sooner or later my collection will be purchased, though nothing has been said about it lately. ${ }^{1}$

For a closer description of my family of Lepidostei, to which belong all the ante-chalk bony fishes, I am anxious to have for dissection a Polypterus Bichir and a Lepidosteus osseus, or any other species belonging exclusively to the present creation. Hitherto, I have only been able to examine and describe the skeleton and external parts. If you could obtain a specimen of both for me you would do me the greatest service. If necessary, I will engage to return the preparations. I beg for this most earnestly. Forgive the many requests contained in this letter, and see in it only my ardent desire to reach my aim, in which you have already helped me so often and so kindly.

\section{HUMBOLDT TO AGASSIZ.}

Sans Souci, July 4, 1833.

... I am happy in your success, my dear Agassiz, happy in your charming letter of May 22d, happy in the hope of having been

1 His collection was finally purchased by the city of Neuchâtel in the spring of 1833 . 
able to do something that may be useful to you for the subscription. The Prince Royal's name seemed to me rather important for you. I have delayed writing, not because I am one of the most persecuted men in Europe (the persecution goes on crescendo; there is not a scholar in Prussia or Germany having anything to ask of the King, or of M. d'Altenstein, who does not think it necessary to make me his agent, with power of attorney), but because it was necessary to await the Prince Royal's return from his military circuit, and the opportunity of speaking to him alone, which does not occur when I am with the King.

Your prospectus is full of interest, and does ample justice to those who have provided you with materials. To name me among them was an affectionate deceit, the ruse of a noble soul like yours; I am a little vexed with you about it. ${ }^{1}$

1 The few words which called forth this protest from Humboldt were as follows. After naming all those from whom he had received help in specimens or otherwise, Agassiz concludes : -

"Finally, I owe to M. de Humboldt not only important notes on fossil fishes, but so many kindnesses in connection with my work that in enumerating them I should fear to wound the delicacy of the giver." This will hardly seem an exaggeration to those who know the facts of the case. 
Here is the beginning of a list. I think the Department of the Mines de Province will take three or four more copies. We have not their answer yet. Do not be frightened at the brevity of the list. . . I I am, however, the least apt of all men in collecting subscriptions, seeing no one but the court, and forced to be out of town three or four days in the week. On account of this same inaptitude, I beg you to send me, through the publisher, only my own three copies, and to address the others, through the publisher also, to the individuals named on the list, merely writing on each copy that the person has subscribed on the list of M. de Humboldt.

With all my affection for you, my dear friend, it would be impossible for me to take charge of the distribution of your numbers or the returns. The publishing houses of Duimmler or of Humblot and Dunker would be useful to you at Berlin. I find it difficult to believe that you will navigate successfully among these literary corsairs! I have had a short eulogium of your work inserted in the Berliner Staats-Zeitung. You see that I do not neglect your interests, and that, for love of you, I even turn journalist. You have omitted to state in your prospectus whether 
your plates are lithographed, as I fear they are, and also whether they are colored, which seems to me unnecessary. Have your superb original drawings remained in your possession, or are they included in the sale of your collection?

I could not make use of your letter to the King, and I have suppressed it. You have been ill-advised as to the forms. "Erhabener" König" has too poetical a turn; we have here the most prosaic and the most degrading official expressions. M. de Pfüel must have some Arch-Prussian with him, who would arrange the formula of a letter for you. At the head there must be "Most enlightened, most powerful King, - all gracious sovereign and lord." Then you begin, "Your Royal Majesty, deeply moved, I venture to lay at your feet most humbly my warmest thanks for the support so graciously granted to the purchase of my collection for the Gymnasium in Neuchâtel. Did I know how to write," etc. The rest of your letter was very good; put only "so much grace as to answer" instead of "so much kindness." You should end with the words, "I remain till death, in deepest reverence, the most humble and faithful servant of your Royal Majesty." The whole on small folio, 
sealed, addressed outside, "To the King's Majesty, Berlin." Send the letter, not through me, but officially, through M. de Pfüel. ${ }^{1}$

The letter to the King is not absolutely necessary, but it will give pleasure, for the King likes any affectionate demonstration from the country that has now become yours. ${ }^{2}$ It will be useful, also, with reference to our request for the purchase of some copies, which we will make to the King as soon as the first number has appeared. Had I obtained the King's name for you to-day (which would have been difficult, since the King detests subscriptions), we should have spoiled the sequence. It seems to me that a letter of acknowledg-

1 At the head there must be "Allerdurchlauchtigster, grossmächtigster König, - allerguädigster König und Herr." Then you begin, "Euer königlichen Majestät, wage ich meinen lebhaftesten Dank für die allergnädigst bewilligte Unterstützung zum Ankauf meiner Sammlung für das Gymnasium in Neuchâtel tief gerührt allerunterthänigst zu Füssen zu legen. Wüsste ich zu schreiben," etc. The rest of your letter was very good, - put only, "so vieler Gnade zu entsprechen "instead of "so vieler Güte." You should end with the words, "Ich ersterbe in tiefster Ehrfurcht Euer königlicher Majestät aller unter thänigsten getreuester." The whole on small folio, sealed, addressed outside, "An des König's Majestät, Berlin."

These forms are no longer in use. They belong to a past generation.

2 It may not be known to all readers that Neuchâtel was then under Prussian sovereignty. 
ment from you to M. Ancillon would be very suitable also. Do not think it is too late. One addresses him as "Monsieur et plus votre Excellence." I am writing tlie most pedantic letter in the world in answer to yours, so full of charm. It must seem to you absurd that I write you in French, when you, French by origin, or rather by language, prefer to write me in German. Pray tell me, did you learn German, which you write with such purity, as a child?

I am happy to see that you publish the whole together. The parceling out of such a work would have led to endless delays; but, for mercy's sake, take care of your eyes; they are ours. I have not neglected the subscriptions in Russia, but I have, as yet, no answer. At a venture, I have placed the name of $M$. von Buch on my list. He is absent; it is said that he will go to Greece this summer. Pray make it a rule not to give away copies of your work. If you follow that inclination you will be pecuniarily ruined.

I wish I could have been present at your course of lectures. What you tell me of them delights me, though I am ready to do battle with you about those metamorphoses of our globe which have even slipped into your title. 
I see by your letter that you cling to the idea of internal vital processes of the earth, that you regard the successive formations as different phases of life, the rocks as products of metamorphosis. I think this symbolical language should be employed with great reserve. I know that point of view of the old "Naturphilosophie;" I have examined it without prejudice, but nothing seems to me more dissimilar than the vital action of the metamorphosis of a plant in order to form the calyx or the flower, and the successive formation of beds of conglomerate. There is order, it is true, in the superposed beds, sometimes an alternation of the same substance, an interior cause, - sometimes even a successive development, starting from a central heat; but can the term life be applied to this kind of movement? Limestone does not generate sandstone. I do not know that there exists what physiologists call a vital force, different from, or opposed to, the physical forces which we recognize in all matter; I think the vital process is only a particular mode of action, of limitation of those physical forces; action, the nature of which we have not yet fully sounded. I believe there are nervous storms (electric) like those which set fire to the atmosphere, 
but that special action which we call organic, in which every part becomes cause or effect, seems to me distinct from the changes which our planet has undergone. I pause here, for I feel that I must annoy you, and I care for you too much to run that risk. Moreover, a superior man like yourself, my dear friend, floats above material things and leaves a margin for philosophic doubt.

Farewell; count on the little of life that remains to me, and on my affectionate devotion. At twenty-six years of age, and possessed of so much knowledge, you are only entering upon life, while I am preparing to depart; leaving this world far different from what I hoped it would be in my youth. I will not forget the Bichir and the Lepidosteus. Remember always that your letters give me the greatest pleasure. . . .

[P. S.] Look carefully at the new number of Poggendorf, in which you will find beautiful discoveries of Ehrenberg (microscopical) on the difference of structure between the brain and the nerves of motion, also upon the crystals forming the silvered portion of the peritoneum of Esox lucius. 
In October, 1833, Agassiz's marriage to Cecile Braun, the sister of his life-long friend, Alexander Braun, took place. He brought his wife home to a small apartment in Neuchâtel, where they began their housekeeping after the simplest fashion, with such economy as their very limited means enforced. Her rare artistic talent, hitherto devoted to her brother's botanical pursuits, now found a new field. Trained to accuracy in drawing objects of Natural History, she had an artist's eye for form and color. Some of the best drawings in the Fossil Fishes and the Fresh-Water Fishes are from her hand. Throughout the summer, notwithstanding the trouble in his eyes, Agassiz had been still pressing on these works. His two artists, Mr. Dinkel and Mr. Weber, the former in Paris, the latter in Neuchatel, were constantly busy on his plates. - Although Agassiz was at this time only twenty-six years of age, his correspondence already shows that the interest of scientific men, all over Europe, was attracted to him and to his work. From investigators of note in his own country, from those of France, Italy, and Germany, from England, and even from America, the distant El Dorado of naturalists in those days, came offers of coöpera- 
tion, accompanied by fossil fishes or by the drawings of rare or unique specimens. $\mathrm{He}$ was known in all the museums of Europe as an indefatigable worker and collector, seeking everywhere materials for comparison.

Among the letters of this date is one from Charpentier, one of the pioneers of glacial investigation, under whose auspices, two years later, Agassiz began his inquiries into glacial phenomena. He writes him from the neighborhood of Bex, his home in the valley of the Rhone, the classic land of glacial work; but he writes of Agassiz's special subjects, inviting him to come and see such fossils as were to be found in his neighborhood, and to investigate certain phenomena of upheaval and of plutonic action in the same region, little dreaming that the young zoölogist was presently to join him in his own chosen field of research.

Agassiz now began also to receive pressing invitations from the English naturalists, from Buckland, Lyell, Murchison, and others, to visit England, and examine their wonderful collections of fossil remains. 
FROM PROFESSOR BUCKLAND TO AGASSIZ.

Oxford, December 25, 1833.

... I should very much like to put into your hands what few materials I possess in the Oxford Museum relating to fossil fishes, and am also desirous that you should see the fossil fish in the various provincial museums of England, as well as in London. Sir Philip Egerton has a very large collection of fishes from Engi and Oeningen, which he wishes to place at your disposition. Like myself, he would willingly send you drawings, but drawings made without knowledge of the anatomical details which you require, cannot well represent what the artist himself does not perceive. I would willingly lend you my specimens, if I could secure them against the barbarous hands of the custom-house officials. What I would propose to you as a means of seeing all the collections of England, and gaining at the same time additional subscriptions for your work, is, that you should come to England and attend the British Association for the Advancement of Science in September next. There you will meet all the naturalists of England, and I do not doubt that among them you will find a good many 
subscribers. You will likewise see a new mine of fossil fishes in the clayey schist of the coal formation at Newhaven, on the banks of the Forth, near Edinburgh. You can also make arrangements to visit the museums of York, Whitby, Scarborough, and Leeds, as well as the museum of Sir Philip Egerton, on your way to and from Edinburgh. You may, likewise, visit the museums of London, Cambridge, and Oxford; everywhere there are fossil fishes; and traveling by coach in England is so rapid, easy, and cheap, that in six weeks or less you can accomplish all that I have proposed. As I seriously hope that you will come to England for the months of August and September, I say nothing at present of any other means of putting into your hands the drawings or specimens of our English fossil fishes. I forgot to mention the very rich collection of fossil fishes in the Museum of Mr. Mantell, at Brighton, where, I think, you could take the weekly steam-packet for Rotterdam as easily as in London, and thus arrive in Neuchâtel from London in a very few days.... 
AGASSIZ TO PROFESSOR BUCKLAND.

.. I I thank you most warmly for the very important information you have so kindly given me respecting the rich collections of England; I will, if possible, make arrangements to visit them this year, and in that case I will beg you to let me have a few letters of recommendation to facilitate my examination of them in detail. Not that I question for a moment the liberality of the English naturalists. All the continental savants who have visited your museums have praised the kindness shown in intrusting to them the rarest objects, and I well know that the English rival other nations in this respect, and even leave them far behind. But one must have merited such favors by scientific labors; to a beginner they are always a free gift, wholly undeserved. . . .

A few months later Agassiz received a very gratifying and substantial mark of the interest felt by English naturalists in his work.

CHARLES LYELL TO LOUIS AGASSIZ.

Somerset House, London, February 4, 1834.

... It is with the greatest pleasure that I announce to you good news. The Geolog- 
ical Society of London desires me to inform you that it has this year conferred upon you the prize bequeathed by Dr. Wollaston. He has given us the sum of one thousand pounds sterling, begging us to expend the interest, or about seven hundred and fifty francs every year, for the encouragement of the science of geology. Your work on fishes has been considered by the Council and the officers of the Geological Society worthy of this prize, Dr. Wollaston having said that it could be given for unfinished works. The sum of thirty guineas, or $£ 3110$ s. sterling, has been placed in my hands, but I would not send you the money before knowing exactly where you were and learning from you where you wish it to be paid. You will probably like an order on some Swiss banker.

I cannot yet give you the extract from the address of the President in which your work is mentioned, but I shall have it soon. In the mean time $I$ am desired to tell you that the Society declines to receive your magnificent work as a gift, but wishes to subscribe for it, and has already ordered a copy from the publishers. . . . 


\section{AGASSIZ TO LYELL.}

Neuchâtel, March 25, 1834.

... You cannot imagine the joy your letter has given me. The prize awarded to me is at once so unexpected an honor and so welcome an aid that I could hardly believe my eyes when, with tears of relief and gratitude, I read your letter. In the presence of a savant, I need not be ashamed of my penury, since I have spent the little I had, wholly in scientific researches. I do not, therefore, hesitate to confess to you that at no time could your gift have given me greater pleasure. Generous friends have helped me to bring out the first number of my "Fossil Fishes;" the plates of the second are finished, but I was greatly embarrassed to know how to print a sufficient number of copies before the returns from the first should be paid in. The text is ready also, so that now, in a fortnight, I can begin the distribution, and, the rotation once established, I hope that preceding numbers will always enable me to publish the next in succession without interruption. I even count upon this resource as affording me the means of making a journey to England before long. If no obstacle arises I hope to accomplish this 
during the coming summer, and to be present at the next meeting of the English naturalists.

I do not live the less happily on account of my anxieties, but I am sometimes obliged to work more than I well can, or ought in reason to do. . . The second number of my "Fossil Fishes" contains the beginning of the anatomy of the fishes, but only such portions as are to be found in the fossil state. I have begun with the scales; later, I treat of the bones and the teeth. Then comes the continuation of the description of the Ganoids and the Scomberoids, and an additional sheet contains a sketch of my ichthyological classification. The plates are even more successful than those of the first number. If all goes well the third number will appear next July. I long to visit your rich collections; I hope that whenever it becomes possible for me to do so, I shall have the good fortune to find you in London. . . .

I have thought a letter addressed to the President of the Society in particular, and to the members in general, would be fitting. Will you have the kindness to deliver it for me to Mr. Murchison? 
The first number of the "Fossil Fishes" had already appeared, and had been greeted with enthusiasm by scientific men. Elie de Beaumont writes Agassiz in June, 1834: "I have read with great pleasure your first number; it promises us a work as important for science as it is remarkable in execution. Do not let yourself be discouraged by obstacles of any kind; they will give way before the concert of approbation which so excellent a work will awaken. I shall always be glad to aid in overcoming any one of them."

Perhaps it is as well to give here a slight sketch of this work, the execution of which was carried on during the next ten years (1833-1843). The inscription tells, in few words, the author's reverence for Humboldt and his personal gratitude to him. "These pages owe to you their existence; accept their dedication." The title gives in a broad outline the comprehensive purpose of the work:

"Researches on the Fossil Fishes: comprising an Introduction to the Study of these Animals; the Comparative Anatomy of Organic Systems which may contribute to facilitate the Determination of Fossil Species ; a New Classification of Fishes expressing their Relations to the Series of Formations; the Explanation of 
the Laws of their Succession and Development during all the Changes of the Terrestrial Globe, accompanied by General Geological Considerations; finally, the Description of about a thousand Species which no longer exist, and whose Characters have been restored from Remains contained in the Strata of the Earth."

The most novel results comprised in this work were : first, the remodeling of the classification of the whole type of fishes, fossil and living, and especially the separation of the Ganoids from all other fishes, under the rank of a distinct order; second, the recognition of those combinations of reptilian and birdlike characters in the earlier geological fishes, which led the author to call them prophetic types; and third, his discovery of an analogy between the embryological phases of the higher present fishes and the gradual introduction of the whole type on earth, the series in growth and the series in time revealing a certain mutual correspondence. As these comprehensive laws have thrown light upon other types of the animal kingdom beside that of fishes, their discovery may be said to have advanced general zoölogy as well as ichthyology. 
The Introduction presents, as it were, the prelude to this vast chapter of natural history in the simultaneous appearance of the four great types of the animal kingdom: Radiates, Mollusks, Articulates, and Vertebrates. Then comes the orderly development of the class by which the vertebrate plan was first expressed, namely, the fishes. Underlying all its divisions and subdivisions, is the average expression of the type in the past and present; the Placoids and Ganoids, with their combination of reptilian and fishlike features, characterizing the earlier geological epochs, while in the later the simple bony fishes, the Cycloids and Ctenoids, take the ascendency. Here, for the first time, Agassiz presents his "synthetic or prophetic types," namely, early types embracing, as it were, in one large outline, features afterward individualized in special groups, and never again reunited. No less striking than these general views of structural relations are the clearness and simplicity with which the distribution of the whole class of fishes in relation to the geological formations, or, in other words, to the physical history of the earth, is shown. In reading this introductory chapter, one familiar with Agassiz as a public teacher will almost hear his voice marshaling the long 
procession of living beings, as he was wont to do, in their gradual introduction upon the earth. Indeed, his whole future work in ichthyology, and one might almost say in general zoölogy, was here sketched.

The technicalities of this work, at once so comprehensive in its combinations and so minute in its details, could interest only the professional reader, but its generalizations may well have a certain attraction for every thoughtful mind. It treats of the relations, anatomical, zoölogical, and geological, between the whole class of fishes, fossil and living, illustrated by numerous plates, while additional light is thrown on the whole by the revelations of embryology.

"Notwithstanding these striking differences," says the author in the opening of the fifth chapter on the relations of fishes in general, "it is none the less evident to the attentive observer that one single idea has presided over the development of the whole class, and that all the deviations lead back to a primary plan, so that even if the thread seem broken in the present creation, one can reunite it on reaching the domain of fossil ichthyology." 1

Having shown how the present creation has 1 Vol. i. chapter v. pp. 92, 93.

VOL. I. 
given him the key to past creations, how the complete skeleton of the living fishes has explained the scattered fragments of the ancient ones, especially those of which the soft cartilaginous structure was liable to decay, he presents two modes of studying the type as a whole; either in its comparative anatomy, including in the comparison the whole history of the type, fossil and living, or in its comparative embryology. "The results," he adds, "of these two methods of study complete and control each other." In all his subsequent researches indeed, the history of the individual in its successive phases went hand in hand with the history of the type. He constantly tested his zoölogical results by his embryological investigations.

After a careful description of the dorsal chord in its embryological development, he shows that a certain parallelism exists between the comparative degrees of development of the vertebral column in the different groups of fishes, and the phases of its embryonic development in the higher fishes. Farther on he shows a like coincidence between the development of the system of fins in the different groups of fishes, and the gradual growth and differentiation of the fins in the embryo of the 
higher living fishes." "There is, then," he concludes, "as we have said above, a certain analogy, or rather a certain parallelism, to be established between the embryological development of the Cycloids and Ctenoids, and the genetic or paleontological development of the whole class. Considered from this point of view, no one will dispute that the form of the caudal fin is of high importance for zoölogical and paleontological considerations, since it shows that the same thought, the same plan, which presides to-day over the formation of the embryo, is also manifested in the successive development of the numerous creation which have formerly peopled the earth." Agassiz says himself in his Preface: "I have succeeded in expressing the laws of succession and of the organic development of fishes during all geological epochs; and science may henceforth, in seeing the changes of this class from formation to formation, follow the progress of organization in one great division of the animal kingdom, through a complete series of the ages of the earth." This is not inconsistent with his position as the leading opponent of the development or Darwinian

1 Recherches sur les Poissons Fossiles, vol i. chapter v. p. 102. 
theories. To him, development meant development of plan as expressed in structure, not the change of one structure into another. To his apprehension the change was based upon intellectual, not upon material causes. $\mathrm{He}$ sums up his own conviction with reference to this question as follows: ${ }^{1}$ "Such facts proclaim aloud principles not yet discussed in science, but which paleontological researches place before the eyes of the observer with an ever-increasing persistency. I speak of the relations of the creation with the creator. Phenomena closely allied in the order of their succession, and yet without sufficient cause in themselves for their appearance; an infinite diversity of species without any common material bond, so grouping themselves as to present the most admirable progressive development to which our own species is linked, are these not incontestable proofs of the existence of a superior intelligence whose power alone could have established such an order of things? ...

"More than fifteen hundred species of fossil fishes, which I have learned to know, tell me that species do not pass insensibly one into

${ }^{1}$ Recherches sur les Poissons Fossiles, vol. i. chapter vi. pp. 171, 172. "Essay on the Classification of Fishes." 
another, but that they appear and disappear unexpectedly, without direct relations with their precursors; for I think no one will seriously pretend that the numerous types of $\mathrm{Cy}-$ cloids and Ctenoids, almost all of which are contemporaneous with one another, have descended from the Placoids and Ganoids. As well might one affirm that the Mammalia, and man with them, have descended directly from fishes. All these species have a fixed epoch of appearance and disappearance; their existence is even limited to an appointed time. And yet they present, as a whole, numerous affinities more or less close, a definite coördination in a given system of organization which has intimate relations with the mode of existence of each type, and even of each species. An invisible thread unwinds itself throughout all time, across this immense diversity, and presents to us as a definite result, a continual progress in the development of which man is the term, of which the four classes of vertebrates are intermediate forms, and the totality of invertebrate animals the constant accessory accompaniment."

The difficulty of carrying out comparisons so rigorous and extensive as were needed in order to reconstruct the organic relations be- 
tween the fossil fishes of all geological formations and those of the present world, is best told by the author." "Possessing no fossil fishes myself, and renouncing forever the acquisition of collections so precious, I have been forced to seek the materials for my work in all the collections of Europe containing such remains; I have, therefore, made frequent journeys in Germany, in France, and in England, in order to examine, describe, and illustrate the objects of my researches. But notwithstanding the cordiality with which even the most precious specimens have been placed at my disposition, a serious inconvenience has resulted from this mode of working, namely, that I have rarely been able to compare directly the various specimens of the same species from different collections, and that I have often been obliged to make my identification from memory, or from simple notes, or, in the more fortunate cases, from my drawings only. It is impossible to imagine the fatigue, the exhaustion of all the faculties, involved in such a method. The hurry of traveling, joined to the lack of the most ordinary facilities for observation, has not rendered my task more

1 Recherches sur les Poissons Fossiles, vol. i. Addition à la Préface. 
easy. I therefore claim indulgence for such of my identifications as a later examination, made at leisure, may modify, and for descriptions which sometimes bear the stamp of the precipitation with which they have been prepared."

It was, perhaps, this experience of Agassiz's earlier life which made him so anxious to establish a museum of comparative zoölogy in this country, - a museum so abundant and comprehensive in material, that the student should not only find all classes of the animal kingdom represented within its walls, but preserved also in such numbers as to allow the sacrifice of many specimens for purposes of comparison and study. He was resolved that no student should stand there baffled at the door of knowledge, as he had often done himself, when shown the one precious specimen, which could not be removed, or even examined on the spot, because unique. 


\section{CHAPTER VIII.}

1834-1837 : ET. $27-30$.

First Visit to England. - Reception by Scientific Men.Work on Fossil Fishes there. - Liberality of English Naturalists. - First Relations with American Science. Farther Correspondence with Humboldt. - Second Visit to England. - Continuation of "Fossil Fishes." - Other Scientific Publications. - Attention drawn to Glacial Phenomena. - Summer at Bex with Charpentier. - Sale of Original Drawings for "Fossil Fishes." - Meeting of Helvetic Society. - Address on Ice-Period. - Letters from Humboldt and Von Buch.

IN August, 1834, according to his cherished hope, Agassiz went to England, and was received by the scientific men with a cordial sympathy which left not a day or an hour of his short sojourn there unoccupied. The following letter from Buckland is one of many proffering hospitality and friendly advice on his arrival.

DR. BUCKLAND TO LOUIS AGASSIZ.

Oxford, August 26, 1834.

... I am rejoiced to hear of your safe arrival in London, and write to say that $\mathrm{I}$ am 
in Oxford, and that I shall be most happy to receive you and give you a bed in my house if you can come here immediately. I expect M. Arago and Mr. Pentland from Paris tomorrow (Wednesday) afternoon. I shall be most happy to show you our Oxford Museum on Thursday or Friday, and to proceed with you toward Edinburgh. Sir Philip Egerton has a fine collection of fossil fishes near Chester, which you should visit on your road. I have partly engaged myself to be with him on Monday, September 1st, but I think it would be desirable for you to go to him Saturday, that you may have time to take drawings of his fossil fishes.

I cannot tell certainly what day I shall leave Oxford until I see M. Arago, whom I hope you will meet at my house, on your arrival in Oxford. I shall hope to see you Wednesday evening or Thursday morning. Pray come to my house in Christ Church, with your baggage, the moment you reach Oxford. ...

Agassiz always looked back with delight on this first visit to Great Britain. It was the beginning of his life-long friendship with Buckland, Sedgwick, Murchison, Lyell, and 
others of like pursuits and interests. Miade welcome in many homes, he could scarcely respond to all the numerous invitations, social and scientific, which followed the Edinburgh meeting.

Guided by Dr. Buckland, to whom not only every public and private collection, but every rare specimen in the United Kingdom, seems to have been known, he wandered from treasure to treasure. Every day brought its revelation, until, under the accumulation of new facts, he almost felt himself forced to begin afresh the work he had believed well advanced. He might have been discouraged by a wealth of resources which seemed to open countless paths, leading he knew not whither, but for the generosity of the English naturalists who allowed him to cull, out of sixty or more collections, two thousand specimens of fossil fishes, and to send them to London, where, by the kindness of the Geological Society, he was permitted to deposit them in a room in Somerset House. The mass of materials once sifted and arranged, the work of comparison and identification became comparatively easy. He sent at once for his faithful artist, Mr. Dinkel, who began, without delay, to copy all such specimens as 
threw new light on the history of fossil fishes, a work which detained him in England for several years.

Agassiz made at this time two friends, whose sympathy and coöperation in his scientific work were invaluable to him for the rest of his life. Sir Philip Egerton and Lord Cole (Earl of Enniskillen) owned two of the most valuable collections of fossil fishes in Great Britain. ${ }^{1}$ To aid him in his researches, their most precious specimens were placed at Agassiz's disposition; his artist was allowed to work for months on their collections, and even after Agassiz came to America, they never failed to share with him, as far as possible, the advantages arising from the increase of their museums. From this time his correspondence with them, and especially with Sir Philip Egerton, is closely connected with the ever-growing interest as well as with the diffculties of his scientific career. Reluctantly, and with many a backward look, he left England in October, and returned to his lectures in Neuchâtel, taking with him such specimens as were indispensable to the progress of his work. Every hour of the following winter which could be spared from his lectures was devoted to his fossil fishes.

1 Now the property of the British Museum. 
A letter of this date from Professor Silliman, of New Haven, Connecticut, marks the beginning of his relations with his future New England home, and announces his first New England subscribers.

Yale College New Haven,

United States of N. America, April 22, 1835. $\}$

... From Boston, March 6th, I had the honor to thank you for your letter of January 5 th, and for your splendid present of your great work on fossil fishes - livraison 1-22 - received, with the plates. I also gave a notice of the work in the April number of the Journal ${ }^{1}$ (this present month), and republished Mr. Bakewell's account of your visit to Mr. Mantell's museum.

In Boston I made some little efforts in behalf of your work, and have the pleasure of naming as follows:-

Harvard University, Cambridge (Cambridge is only four miles from Boston), by Hon. Josiah Quincy, President.

Boston Athenæum, by its Librarian.

Benjamin Green, Esq., President of the Boston Natural History Society.

I shall make application to some other insti-

1 The American Journal of Science and Arts. 
tutions or individuals, but do not venture to promise anything more than my best exertions....

Agassiz little dreamed, as he read this letter, how familiar these far-off localities would become to him, or how often, in after years, he would traverse by day and by night the four miles which lay between Boston and his home in Cambridge.

Agassiz still sought and received, as we see by the following letter, Humboldt's sympathy in every step of his work.

\section{HUMBOLDT TO LOUIS AGASSIZ.}

Berlin, May, 1835.

I am to blame for my neglect of you, my dear friend, but when you consider the grief which depresses me, ${ }^{1}$ and renders me unfit to keep up my scientific connections, you will not be so unkind as to bear me any ill-will for my long silence. You are too well aware of my high esteem for your talents and your character - you know too well the affectionate friendship I bear you - to fear for a moment that you could be forgotten.

I have seen the being I loved most, and 1 Owing to the death of his brother, William von Humboldt. 
who alone gave me some interest in this arid land, slowly decline. For four long years my brother had suffered from a weakness of all the muscles, which made me always fear that the seat of the trouble was the medulla oblongata. Yet his step was firm; his head was entirely clear. The higher intellectual faculties retained all their energy. He was engaged from twelve to thirteen hours a day on his works, reading or rather dictating, for a nervous trembling of the hand prevented him from using a pen. Surrounded by a numerous family; living on a spot created, so to speak, by himself, and in a house which he had adorned with antique statues; withdrawn also from affairs, he was still attached to life. The illness which carried him off in ten days - an inflammation of the chest - was but a secondary symptom of his disease. He died without pain, with a strength of character and a serenity of mind worthy of the greatest admiration. It is cruel to see so noble an intelligence struggle during ten long days against - physical destruction. We are told that in great grief we should turn with redoubled energy to the study of nature. The advice is easy to give; but for a long time even the wish for distraction is wanting. 
My brother leaves two works which we intend to publish: one upon the languages and ancient Indian civilization of the Asiatic archipelago, and the other upon the structure of languages in general, and the influence of that structure upon the intellectual development of nations. This last work has great beauty of style. We shall soon begin the publication of it. My brother's extensive correspondence with all those countries over which his philological studies extended brings upon me just at present, such a multiplicity of occupations and duties that I can only write you these few lines, my dear friend, as a pledge of my constant affection, and, I may also add, my admiration of your eminent works. It is a pleasure to watch the growing renown of those who are dear to us; and who should merit success more than you, whose elevation of character is proof against the temptations of literary self-love? I thank you for the little you have told me of your home life. It is not enough to be praised and recognized as a great and profound naturalist; to this one must add domestic happiness as well. . .

I am about finishing my long and wearisome work of (illegible); a critical examination into the geography of the Middle Ages, of 
which fifty sheets are already printed. I will send you the volumes as soon as they appear, in octavo. I devoured your fourth number; the plates are almost finer than the previous ones; and the text, though I have only looked it through hastily, interested me deeply, especially the analytical catalogue of Bolca, and the more general and very philosophical views of fishes in general, pp. 57-64. The latter is also remarkable in point of style. . . .

M. von Buch, who has just left me, sends you a warm greeting. None the less does he consider the method of issuing your text in fragments from different volumes, altogether diabolical. I also complain a little, though in all humility; but I suppose it to be connected with the difficulty of concluding any one family, when new materials are daily accumulating on your hands. Continue then as before. In my judgment, M. Agassiz never does wrong. ...

The above letter, though written in May, did not reach Agassiz until the end of July, when he was again on his way to England, where his answer is dated. 
AGASSIZ TO HUMBOLDT.

(London), October - 1835.

- I cannot express to you my pleasure in reading your letter of May 10th (which was, unhappily, only delivered to me on my passage through Carlsruhe, at the end of July). . . To know that I have occupied your thoughts a moment, especially in days of trial and sorrow such as you have had to bear, raises me in my own eyes, and redoubles my hope for the future. And just now such encouragement is particularly cheering under the difficulties which I meet in completing my task in England. I have now been here nearly two months, and I hope before leaving to finish the description of all that I brought together at the Geological Society last year. Knowing that you are in Paris, however, I cannot resist the temptation of going to see you; indeed, should your stay be prolonged for some weeks, it would be my most direct path for home. I should like to tell you a little of what I have done, and how the world has gone with me since we last met. . . I have certainly committed an imprudence in throwing myself into an enterprise so vast in proportion to my means as my "Fossil voL. I. 
Fishes." But, having begun it, I have no alternative; my only safety is in success. I have a firm conviction that I shall bring my work to a happy issue, though often in the evening I hardly know how the mill is to be turned to-morrow. . . .

By a great good fortune for me, the British Association, at the suggestion of Buckland, Sedgwick, and Murchison, has renewed, for the present year, its vote of one hundred guineas toward the facilitating of researches upon the fossil fishes of England, and I hope that a considerable part of this sum may be awarded to me, in which case I may be able to complete the greater number of the drawings I need. If I had obtained in France only half the subscriptions I have had in England, I should be afloat; but thus far M. Baillière has only disposed of some fifteen copies. . . . My work advances fairly; I shall soon have described all the species I know, numbering now about nine hundred. I need some weeks in Paris for the comparison of several tertiary species with living ones in order to satisfy myself of their specific identity, and then my task will be accomplished. Next comes the putting in order of all my notes. My long vacations will give me time to do this with the greatest care. ... 
His second visit to England, during which the above letter was written, was chiefly spent in reviewing the work of his artist, whom he now reinforced with a second draughtsman, M. Weber, the same who had formerly worked with him in Munich. He also attended the meeting of the British Association in Dublin, stayed a few days at Oulton Park for another look at the collections of Sir Philip Egerton, made a second grand tour among the other fossil fishes of England and Ireland, and returned to Neuchâtel, leaving his two artists in London with their hands more than full.

While Agassiz thus pursued his work on fossil fishes with ardor and an almost perilous audacity, in view of his small means, he found also time for various other investigations. During the year 1836, though pushing forward constantly the publication of the "Poissons Fossiles," his "Prodromus of the Class of Echinodermata" appeared in the Memoirs of the Natural History Society of Neuchâtel, as well as his paper on the fossil Echini belonging to the Neocomien group of the Neuchâtel Jura, accompanied by figures. Not long after, he published in the Memoirs of the Helvetic Society his descriptions of fossil Echini peculiar to Switzerland, and issued also the first 
number of a more extensive work, "Monographie d'Echinodermes." During this year he received a new evidence of the sympathy of the English naturalists, in the Wollaston medal awarded to him by the London Geological Society.

The summer of 1836 was an eventful one for Agassiz, - the opening, indeed, of a new and brilliant chapter in his life. The attention of the ignorant and the learned had alike been called to the singular glacial phenomena of movement and transportation in " the Alpine valleys. The peasant had told his strange story of boulders carried on the back of the ice, of the alternate retreat and advance of glaciers, now shrinking to narrower limits, now plunging forward into adjoining fields, by some unexplained power of expansion and contraction. Scientific men were awake to the interest of these facts, but had considered them only as local phenomena. Venetz and Charpentier were the first to detect their wider significance. The former traced the ancient limits of the Alpine glaciers as defined by the frame-work of débris or loose material they had left behind them; and Charpentier went farther, and affirmed that all the erratic boulders scattered over the plain of Switzer- 
land and on the sides of the Jura had been thus distributed by ice and not by water, as had been supposed.

Agassiz was among those who received this hypothesis as improbable and untenable. Still, he was anxious to see the facts in place, and Charpentier was glad to be his guide. $\mathrm{He}$ therefore passed his vacation, during this summer of 1836, at the pretty town of Bex, in the valley of the Rhone. Here he spent a number of weeks in explorations, which served at the same time as a relaxation from his more sedentary work. He went expecting to confirm his own doubts, and to disabuse his friend Charpentier of his errors. But after visiting with him the glaciers of the Diablerets, those of the valley of Chamounix, and the moraines of the great valley of the Rhone and its principal lateral valleys, he came away satisfied that a too narrow interpretation of the phenomena was Charpentier's only mistake.

During this otherwise delightful summer, he was not without renewed anxiety lest he should be obliged to suspend the publication of the Fossil Fishes for want of means to carry it on. On this account he writes from Bex to Sir Philip Egerton in relation to the sale of his original drawings, the only property he pos- 
sessed. "It is absolutely impossible," he says, "for me to issue even another number until this sale is effected. . . . I shall consider myself more than repaid if I receive, in exchange for the whole collection of drawings, simply what I have expended upon them, provided I may keep those which have yet to be lithographed until that be done."

Sir Philip made every effort to effect a sale to the British Museum. He failed at the moment, but the collection was finally purchased and presented to the British Museum by a generous relative of his own, Lord Francis Egerton. In the mean time, Sir Philip and Lord Cole, in order to make it possible for Agassiz to retain the services of Mr. Dinkel, proposed to pay his expenses while he was drawing such specimens from their own collections as were needed for the work. These drawings were, of course, finally to remain their own property.

During his sojourn at Bex, Agassiz's intellect and imagination had been deeply stirred by the glacial phenomena. In the winter of 1837, on his return to Neuchâtel, he investigated anew the slopes of the Jura, and found that the facts there told the same story. Although he resumed with unabated ardor his 
various works on fishes, radiates, and mollusks, a new chapter of nature was all the while unfolding itself in his fertile brain. When the Helvetic Association assembled at Neuchâtel in the following summer, the young president, from whom the members had expected to hear new tidings of fossil fishes, startled them by the presentation of a glacial theory, in which the local erratic phenomena of the Swiss valleys assumed a cosmic sig- nificance. It is worthy of remark here that the first large outlines in which Agassiz, when a young man, planned his intellectual work gave the key-note to all that followed. As the generalizations on which all his future zoölogical researches were based, are sketched in the Preface to his "Poissons Fossiles," so his opening address to the Helvetic Society in 1837 unfolds the glacial period as a whole,

- much as he saw it at the close of his life, after he had studied the phenomena on three continents. In this address he announced his conviction that a great ice-period, due to a temporary oscillation of the temperature of the globe, had covered the surface of the earth with a sheet of ice, extending at least from the north pole to Central Europe and Asia. "Siberian winter," he says, "established itself 
for a time over a world previously covered with a rich vegetation and peopled with large mammalia, similar to those now inhabiting the warm regions of India and Africa. Death enveloped all nature in a shroud, and the cold, having reached its highest degree, gave to this mass of ice, at the maximum of tension, the greatest possible hardness." In this novel presentation the distribution of erratic boul-

* ders, instead of being classed among local phenomena, was considered "as one of the accidents accompanying the vast change occasioned by the fall of the temperature of our globe before the commencement of our epoch."

This was, indeed, throwing the gauntlet down to the old expounders of erratic phenomena upon the principle of floods, freshets, and floating ice. Many well-known geologists were present at the meeting, among them Leopold von Buch, who could hardly contain his indignation, mingled with contempt, for what seemed to him the view of a youthful and inexperienced observer. One would have liked to hear the discussion which followed, in special section, between Von Buch, Charpentier, and Agassiz. Elie de Beaumont, who should have made the fourth, did not arrive till later. Difference of opinion, however, never dis- 
turbed the cordial relation which existed between Von Buch and his young opponent. Indeed, Agassiz's reverence and admiration for Von Buch was then, and continued throughout his life, deep and loyal.

Not alone from the men who had made these subjects their special study, did Agassiz meet with discouragements. The letters of his beloved mentor, Humboldt, in 1837, show how much he regretted that any part of his young friend's energy should be diverted from zoölogy, to a field of investigation which he then believed to be one of theory rather than of precise demonstration. He was, perhaps, partly influenced by the fact that he - saw through the prejudiced eyes of his friend Von Buch. "Over your and Charpentier's moraines," he says, in one of his letters, "Leopold von Buch rages, as you may already know, considering the subject, as he does, his exclusive property. But I too, though by no means so bitterly opposed to new views, and ready to believe that the boulders have not all been moved by the same means, am yet inclined to think the moraines due to more local causes."

The next letter shows that Humboldt was seriously anxious lest this new field of activ- 
ity, with its fascinating speculations, should draw Agassiz away from his ichthyological researches.

HUMBOLDT TO AGASSIZ.

Berlin, December 2, 1837.

I have this moment received, my dear friend, by the hand of M. de Werther, the cabinet minister, your eighth and ninth numbers, with a fine pamphlet of text. I hasten to express my warm thanks, and I congratulate the public on your somewhat tardy resolution to give a larger proportion of text. One should flatter neither the king, nor the people, nor one's dearest friend. I maintain, therefore, that no one has told you forcibly enough how the very persons who justly admire your work, constantly complain of this fragmentary style of publication, which is the despair of those who have not the leisure to place your scattered sheets where they belong and disentangle the skein. ${ }^{1}$

I think you would do well to publish for a while more text than plates. You could do

1 Owing to the irregularity with which he received and was forced to work up his material, Agassiz was often either in advance or in arrears with certain parts of his subject, so that his plates and his text did not keep pace with each other, thus causing his readers much annoyance. 
this the better because your text is excellent, full of new and important ideas, expressed with admirable clearness. The charming letter (again without a date) which preceded your package impressed me painfully. I see you are ill again; you complain of congestion of the head and eyes. For mercy's sake take care of your health which is so dear to us. I am afraid you work too much, and (shall I say it frankly?) that you spread your intellect over too many subjects at once. I think that you should concentrate your moral and also your pecuniary strength upon this beautiful work on fossil fishes. In so doing you will render a greater service to positive geology, than by these general considerations (a little icy withal) on the revolutions of the primitive world; considerations which, as you well know, convince only those who give them birth. In accepting considerable sums from England, you have, so to speak, contracted obligations to be met only by completing a work which will be at once a monument to your own glory and a landmark in the history of science. Admirable and exact as your researches on other fossils are, your contemporaries claim from you the fishes above all. You will say that this is making you the slave 
of others; perfectly true, but such is the pleasing position of affairs here below. Have I not been driven for thirty-three years to busy myself with that tiresome America, and am I not, even yet, daily insulted because, after publishing thirty-two volumes of the great edition in folio and in quarto, and twelve hundred plates, one volume of the historical section is wanting? We men of letters are the servants of an arbitrary master, whom we have imprudently chosen, who flatters and pets us first, and then tyrannizes over us if we do not work to his liking. You see, my dear friend, I play the grumbling old man, and, at the risk of deeply displeasing you, place myself on the side of the despotic public. ...

With reference to the general or periodical lowering of the temperature of the globe, I have never thought it necessary, on account of the elephant of the Lena, to admit that sudden frost of which Cuvier used to speak. What I have seen in Siberia, and what has been observed in Captain Beechey's expedition on the northwest coast of America, simply proves that there exists a layer of frozen drift, in the fissures of which (even now) the muscular flesh of any animal which should accidentally fall into them would be preserved intact. 
It is a slight local phenomenon. To me, the ensemble of geological phenomena seems to prove, not the prevalence of this glacial surface on which you would carry along your boulders, but a very high temperature spreading almost to the poles, a temperature favorable to organizations resembling those now living in the tropics. Your ice frightens me, and gladly as I would welcome you here, my dear friend, I think, perhaps, for the sake of your health, and also that you may not see this country, always so hideous, under a sheet of snow and ice (in February), you would do better to come two months later, with the first verdure. This is suggested by a letter received yesterday by M. d'O_—, which alarmed me a little, because the state of your eyes obliged you to write by another hand. Pray do not think of traveling before you are quite well. I close this letter, feeling sure that it does not contain a line which is not an expression of friendship and of the high esteem I bear you. The magnificence of your last numbers, eight and nine, cannot be told. How admirably executed are your Macropoma, the Ophiopris procerus, Mantell's great beast, the minute details of the Dercetis, Psammodus, ... the skeletons. . . There is nothing 
like it in all that we possess upon vertebrates. I have also begun to study your text, so rich in well arranged facts; the monograph of the Lepidostei, the passage upon the bony rays, and, dear Agassiz, I could hardly believe my eyes, sixty-five continuous pages of the third volume, without interruption! You will spoil the public. But, my good friend, you have already information upon a thousand species; "claudite jam rivos!" You say your work can go on if you have two hundred subscribers; but if you continue to support two traveling draughtsmen, I predict, as a practical man, that it cannot go on. You cannot even publish what you have gathered in the last five years. Consider that in attempting to give a review of all the fossil fishes which now exist ' in collections, you pursue a phantom which ever flies before you. Such a work would not be finished in less than fifteen years, and besides, this now is an uncertain element. Cannot you conquer yourself so far as to finish what you have in your possession at present? Recall your artists. With the reputation you enjoy in Europe, whatever might essentially change your opinion on certain organisms would willingly be sent to you. If you continue to keep two ambassadors in for- 
eign lands, the means you destine for the engraving and printing will soon be absorbed. You will struggle with domestic difficulties, and at sixty years of age (tremble at the sight of this number!) you will be as uncertain as you are to-day, whether you possess, even in your collection of drawings, all that is to be found among amateurs. How exhaust an ocean in which the species are indefinitely increasing? Finish, first, what you have this December, 1837, and then, if the subject does not weary you, publish the supplements in 1847. You must not forget that these supplements will be of two kinds: 1st. Ideas which modify some of your old views. 2d. New species. Only the first kind of supplement would be really desirable. Furthermore, you must regain your intellectual independence and not let yourself be scolded any more by M. de Humboldt. Little will it avail you should I vanish from the scene of this world with your fourteenth number! When I am a fossil in my turn I shall still appear to you as a ghost, having under my arm the pages you have failed to interpolate and the volume of that eternal America which I owe to the public. I close with a touch of fun, in order that my letter may seem a little less 
like preaching. A thousand affectionate remembrances. No more ice, not much of echinoderms, plenty of fish, recall of ambassadors in partibus, and great severity toward the book-sellers, an infernal race, two or three of whom have been killed under me.

\section{A. de Humboldt.}

I sigh to think of the trouble my horrible writing will give you.

A letter of about the same date from Von Buch shows that, however he might storm at Agassiz's heterodox geology, he was in full sympathy with his work in general.

LEOPOLD VON BUCH TO LOUIS AGASSIZ.

December 22, 1837.

... Pray reinstate me in the good graces of my unknown benefactor among you. By a great mistake the reports of the Society forwarded to me from Neuchâtel have been sent back. As it is well known at the post-office that I do not keep the piles of educational journals sent to me from France, the postage on them being much too heavy for my means, they took it for granted that this journal, the charges on which amounted to several crowns, was of the number. I am very sorry. I do 
not even know the contents of the journal, but I suppose it contained papers of yours, full of genius and ardor. I like your way of looking at nature, and I think you render great service to science by your observations. A right spirit will readily lead you to see that this is the true road to glory, far preferable to the one which leads to vain analogies and speculations, the time for which is long past. I am grieved to hear that you are not well, and that your eyes refuse their service. M. de Humboldt tells me that you are seeking a better climate here, in the month of February. You may find it, perhaps, thanks to our stoves. But as we shall still have plenty of ice in the streets, your glacial opinions will not find a marlzet at that season. I should like to present you with a memoir or monograph of mine, just published, on Spirifer and Orthis, but I will take good care to let no one pay postage on a work which, by its nature, can have but a very limited interest. . . . I will await your arrival to give you these descriptions. I am expecting the numbers of your Fossil Fishes, which have not yet come. Humboldt often speaks of them to me. Ah! how much I prefer you in a field which is wholly your own than in one where you break in VOL. I. 
upon the measured and cautious tread, introduced by Saussure in geology. You, too, will reconsider all this, and will yet treat the views of Saussure and Escher with more respect. Everything here turns to infusoria. Ehrenberg has just discovered that an apparently sandy deposit, twenty feet in thickness, under the "Luneburgerheyde," is composed entirely of infusoria of a kind still living in the neighborhood of Berlin. This layer rests upon a brown deposit known to be ten feet in thickness. The latter consists, for one fifth of the depth, of pine pollen, which burns. The rest is of infusoria. Thus these animals, which the naked eye has not power to discern, have themselves the power to build up mountain chains.... 


\section{CHAPTER IX.}

1837-1839 : ÆT. 30-32.

Invitation to Professorships at Geneva and Lausanne. -

Death of his Father. - Establishment of Lithographic Press at Neuchâtel. - Researches upon Structure of Mollusks. - Internal Casts of Shells. - Glacial Explorations. - Views of Buckland. - Relations with Arnold Guyot. Their Work together in the Alps. - Letter to Sir Philip Egerton concerning Glacial Work. - Summer of 1839. Publication of "Etudes sur les Glaciers."

Although Agassiz's daring treatment of the glacial phenomena had excited much opposition and angry comment, it had also made a powerful impression by its eloquence and originality. To this may be partly due the fact that about this time he was strongly urged from various quarter's to leave Neuchâtel for some larger field. One of the most seductive of these invitations, owing to the affectionate spirit in which it was offered, came through Monsieur de la Rive, in Geneva. 
M. AUGUSTE DE LA RIVE TO LOUIS AGASSIZ.

Geneva, May 12, 1836.

... I have not yet received your address. I hope you will send it to me without delay, for I am anxious to bring it before our readers. I hope also that you will not forget what you have promised me for the "Bibliothèque Universelle." I am exceedingly anxious to have your coöperation; the more so that it will reinforce that of several distinguished savants whose assistance I have recently secured.

If I weary you with a second letter, however, it is not only to remind you of your promise about the "Bibliothèque Universelle," but for another object still more important and urgent. The matter stands thus. Our academic courses have just opened under favorable auspices. The number of students is much increased, and, especially, we have a good many from Germany and England. This circumstance makes us feel more strongly the importance of completing our organization, and of doing this wisely and quickly. I will not play the diplomat with you, but will frankly say, without circumlocution, that you seem to me the one essential, the one indis- 
pensable man. After having talked with some influential persons here, I feel sure that if you say to me, "I will come," I can obtain for you the following conditions: 1st. A regular salary of three thousand francs, beside the student fees, which, in view of the character of your instruction, your reputation, and the novelty of your course, I place too low at a thousand francs; of this I am convinced. $2 \mathrm{~d}$. The vacant professorship is one of geology and mineralogy, but should you wish it De la Planche will continue to teach the mineralogy, and you will replace it by paleontology, or any other subject which may suit you.... Add to this resource that of a popular course for the world outside, ladies and others, which you might give in the winter, as at Neuchâtel. The custom here is to pay fifty francs for the course of from twenty-five to thirty lectures. You will easily see that for such a course you would have at least as large an audience here as at Neuchâtel. This is the more likely because there is a demand for these courses, Pictet being dead, and M. Rossi and M. de Castella having ceased to give them. No one has come forward as their heir, fine as the inheritance is; some are too busy, others have not the kind of talent 
needed, and none have attempted to replace these gentlemen in this especial line, one in which you excel, both by your gifts and your fortunate choice of a subject more in vogue just now than any other. Come then, to work in this rich vein before others present themselves for the same purpose. Finally, since I must make up your budget, the "Bibliothèque Universelle," which pays fifty francs a sheet, would be always open to you; there you could bring the fruits of your productive leisure. Certainly it would be easy for you to make in this way an additional thousand francs.

Here, then, is a statement, precise and full, of the condition of things, and of what you may hope to find here. The moment is propitious; there is a movement among us just now in favor of the sciences, and this winter the plan of a large building for our museum and library will be presented to our common council. The work should begin next summer; you well know how much we should value your ideas and your advice on this subject. There may also be question of a director for the museum, and of an apartment for him in the new edifice; you will not doubt to whom such a place would be offered. But let 
us not draw upon the future ; let us limit ourselves to the present, and see whether what I propose suits you. ... Come! let yourself be persuaded. Sacrifice the capital to a provincial town. At Berlin, no doubt, you would be happy and honored; at Geneva, you would be the happiest, the most honored. Look at - , who shone as a star of the first magnitude at Geneva, and who is but a star of second or third rank in Paris. This, to be sure, would not be your case; nevertheless, I am satisfied that at Geneva, where you would be a second de Saussure, your position would be still more brilliant. I know that these motives of scientific self-love have little weight with you; nevertheless, wishing to omit nothing, I give them for what they are worth. But my hope rests far more on the arguments I have first presented; they come from the heart, and with you the heart responds as readily as the genius. But enough! I will not fatigue you with farther considerations. I think I have given you all the points necessary for your decision. Be so kind as to let me know as soon as possible what you intend to do. Have the kindness also not to speak of the contents of this letter, and remember that it is not the Rector of the Academy of Geneva, but the 
Professor Auguste de la Rive, who writes in his own private person. Promptitude and silence, then, are the two recommendations which I make to you while we await the Yes we so greatly desire. ..

More tempting still must have been the official invitation received a few months later to a professorship at Lausanne, strengthened as it was by the affectionate entreaties of relations and friends, urging him for the sake of family ties and patriotism to return to the canton where he had passed his earlier years. But he had cast in his lot with the Neuchâtelois and was proof against all arguments. He remained faithful to the post he had chosen until he left it, temporarily as he then believed, to come to America. The citizens of his adopted town expressed their appreciation of his loyalty to them in a warm letter of thanks, begging, at the same time, his acceptance of the sum of six thousand francs, payable by installments during three years.

The summer of 1837 was a sad one to Agassiz and to his whole family; his father died at Concise, carried off by a fever while still a comparatively young man. The pretty parsonage, to which they were so much at. 
tached, passed into other hands, and thenceforward the home of Madame Agassiz was with her children, among whom she divided her time.

In 1838 Agassiz founded a lithographic printing establishment in Neuchâtel, which was carried on for many years under his direction. Thus far his plates had been lithographed in Munich. Their execution at such a distance involved constant annoyance, and sometimes great waste of time and money, in sending the proofs to and fro for correction. The scheme of establishing a lithographic press, to be in a great degree at his charge, was certainly an imprudent one for a poor man; but Agassiz hoped not only to facilitate his own publications by this means, but also to raise the standard of execution in works of a purely scientific character. Supported partly by his own exertions, partly by the generosity of others, the establishment was almost exclusively dependent upon him for its unceasing activity. He was fortunate in securing for its head M. Hercule Nicolet, a very able lithographic artist, who had had much experience in engraving objects of natural history, and was specially versed in the recently invented art of chromatic lithography. 
Agassiz was now driving all his steeds abreast. Beside his duties as professor, he was printing at the same time his "Fossil Fishes," his "Fresh-Water Fishes," and his investigations on fossil Echinoderms and Mollusks, - the illustrations for all these various works being under his daily supervision. The execution of these plates, under M. Nicolet's care, was admirable for the period. Professor Arnold Guyot, in his memoir of Agassiz, says of the plates for the "Fresh-Water Fishes": "We wonder at their beauty, and at their perfection of color and outline, when we remember that they were almost the first essays of the newly-invented art of lithochromy, produced at a time when France and Belgium were showering rewards on very inferior work of the kind, as the foremost specimens of progress in the art."

All this work could hardly be carried on single handed. In 1837 M. Edouard Desor joined Agassiz in Neuchâtel, and became for many years his intimate associate in scientific labors. A year or two later M. Charles Vogt also united himself to the band of investigators and artists who had clustered about Agassiz as their central force. M. Ernest Favre says of this period of his life: "He displayed 
during these years an incredible energy, of which the history of science offers, perhaps, no other example."

Among his most important zoölogical researches at this time were those upon mollusks. His method of studying this class was too original and too characteristic to be passed by without notice The science of conchology had heretofore been based almost wholly upon the study of the empty shells. To Agassiz this seemed superficial. Longing to know more of the relation between the animal and its outer covering, he bethought himself that the inner moulding of the shell would give at least the form of its old inhabitant. For the practical work he engaged an admirable moulder, M. Stahl, who continued to be one of his staff at the lithographic establishment until he became permanently employed at the Jardin des Plantes. With his help and that of M. Henri Ladame, professor of physics and chemistry at Neuchâtel, who prepared the delicate metal alloys in which the first mould was taken, Agassiz obtained casts in which the form of the animals belonging to the shells was perfectly reproduced. This method has since passed into universal use. By its aid he obtained a new means of ascertaining the re- 
lations between fossil and living mollusks. It was of vast service to him in preparing his "Etudes critiques sur les Mollusques fossiles," - a quarto volume with nearly one hundred plates.

The following letter to Sir Philip Egerton gives some account of his undertakings at this time, and of the difficulties entailed upon him by their number and variety.

LOUIS AGASSIZ TO SIR PHILIP EGERTON.

Neuchâtel, August 10, 1838.

... These last months have been a time of trial to me, and I have been forced to give up my correspondence completely in order to meet the ever-increasing demands of my work. You know how difficult it is to find a quiet moment and an easy mind for writing, when one is pursued by printing or lithographic proofs, and forced besides to prepare unceasing occupation for numerous employés. Add to this the close research required by the work of editing, and you surely will find an excuse for my delay. I think I have already written you that in order to have everything under my own eye, I had founded a lithographic establishment at Neuchâtel in the hope of avoiding in future the procrastinations to which 
my proofs were liable when the work was done at Munich. . . . I hope that my new publications will be sufficiently well received to justify me in supporting an establishment unique of its kind, which I have founded solely in the interest of science and at the risk of my peace and my health. If I give you all these details, it is simply to explain my silence, which was caused not by pure negligence, but by the demands of an undertaking in the success of which my very existence is involved.... This week I shall forward to the Secretary of the British Association for the Advancement of Science all that I have been able to do thus far, being unable to bring it myself, as I had hoped. You would oblige me greatly if you would give a look at these different works, which may, I hope, have various claims on your interest. First, there is the tenth number of the "Fossil Fishes," though the whole supply of publisher's copies will only be sent a few weeks later. Then there are the seven first plates of my sea-urchins, engraved with much care and with many details. A third series of plates relates to critical studies on fossil mollusks, little or erroneously known, and on their internal casts. This is a quite novel side of the study of shells, and 
will throw light on the organization of animals known hitherto only by the shell. I have made a plaster collection of them for the Geological Society. They have been packed some time, but my late journey to Paris has prevented me from forwarding them till now. As soon as I have a moment, I shall make out the catalogue and send it on. When you go to London, do not fail to examine them; the result is curious enough. Finally, the plates for the first number of my "Fresh-Water Fishes" are in great part finished, and also included in my package for Newcastle... . The plates are executed by a new process, and printed in various tints on different stones, resulting in a remarkable uniformity of coloring in all the impressions....

Such are the new credentials with which I present myself, as I bring my thanks for the honor paid to me by my nomination for the vacancy in the Royal Society of London. If unbounded devotion to the interests of science constituted a sufficient title to such a distinction, I should be the less surprised at the announcement contained in your last letter. The action of the Royal Society, so flattering to the candidate of your choice, has satisfied a desire which I should hardly have dared to 
form for many a year, - that of becoming a member of a body so illustrious as the Royal Society of London. ...

Each time I write I wish I could close with the hope of seeing you soon; but I must work incessantly; that is my lot, and the happiness I find in it gives a charm to my occupations however numerous they may be. . . .

While Agassiz's various zoölogical works were thus pressed with unceasing activity, the glaciers and their attendant phenomena, which had so captivated his imagination, were ever present to his thought. In August of the year 1838, a year after he had announced at the meeting of the Helvetic Society his comprehensive theory respecting the action of ice over the whole northern hemisphere, he made two important excursions in the Alps. The first was to the valley of Hassli, the second to the glaciers of Mont Blanc. In both he was accompanied by his scientific collaborator, M. Desor, whose intrepidity and ardor hardly fell short of his own; by $\mathrm{Mr}$. Dinkel as artist, and by one or two students and friends. These excursions were a kind of prelude to his more prolonged sojourns on the Alps, and to the series of obsorvations car- 
ried on by him and his companions, which attracted so much attention in later years. But though Agassiz carried with him, on these first explorations, only the simplest means of investigation and experiment, they were no amateur excursions. On these first Alpine journeys he had in his mind the sketch he meant to fill out. The significance of the phenomena was already clear to him. What he sought was the connection. Following the same comparative method, he intended to track the footsteps of the ice as he had gathered and put together the fragments of his fossil fishes, till the scattered facts should fall into their natural order once more and tell their story from beginning to end.

In his explorations of 1838 he found everywhere the same phenomena; the grooved and polished and graven surfaces and the rounded and modeled rocks, often lying far above and beyond the present limits of the glaciers; the old moraines, long deserted by the ice, but defining its ancient frontiers; the erratic blocks, transported far from their place of origin and disposed in an order and position unexplained by the agency of water.

These excursions, though not without their dangers and fatigues, were full of charm for 
men who, however serious their aims, were still young enough to enter like boys into the spirit of adventure. Agassiz himself was but thirty-one; an ardent pedestrian, he delighted in feats of walking and climbing. His friend Dinkel relates that one day, while pausing at Grindelwald for refreshment, they met an elderly traveler who asked him, after listening awhile to their gay talk, in which appeals were constantly made to "Agassiz," if that was perhaps the son of the celebrated professor of Neuchâtel. The answer amazed him; he could hardly believe that the young man before him was the naturalist of European reputation. In connection with this journey occurs the first attempt at an English letter found among Agassiz's papers. It is addressed to Buckland, and contains this passage: "Since I saw the glaciers I am quite of a snowy humor, and will have the whole surface of the earth covered with ice, and the whole prior creation dead by cold. In fact, I am quite satisfied that ice must be taken [included] in every complete explanation of the last changes which occurred at the surface of Europe." Considered in connection with their subsequent work together in the ancient ice-beds and moraines of England, Scotland, Ireland, VOL $I$. 
and Wales, it is curious to find Buckland answering: "I am sorry that I cannot entirely adopt the new theory you advocate to explain transported blocks by moraines; for supposing it adequate to explain the phenomena of Switzerland, it would not apply to the granite blocks and transported gravel of England, which I can only explain by referring to currents of water." During the same summer Mrs. Buckland writes from Interlaken, in the course of a journey in Switzerland with her husband. ... "We have made a good tour of the Oberland and have seen glaciers, etc., but Dr. Buckland is as far as ever from agreeing with you." We shall see hereafter how completely he became a convert to Agassiz's glacial theory in its widest acceptation.

One friend, scarcely mentioned thus far in this biography, was yet, from the beginning, the close associate of Agassiz's glacier work. Arnold Guyot and he had been friends from boyhood. Their university life separated them for a time, Guyot being at Berlin while Agassiz was at Munich, and they became colleagues at Neuchâtel only after Agassiz had been for some years established there. From that time forward there was hardly any break in their intercourse; they came to America at about 
the same time, and finally settled as professors, the one at Harvard College, in Cambridge, Massachusetts, and the other at the College of New Jersey, in Princeton. They shared all their scientific interests; and when they were both old men, Guyot brought to Agassiz's final undertaking, the establishment of a summer school at Penilzese, a coöperation as active and affectionate as that he had given in his youth to his friend's scheme for establishing a permanent scientific summer station in the high Alps.

In a short visit made by Agassiz to Paris in the spring of 1838 he unfolded his whole plan to Guyot, then residing there, and persuaded him to undertake a certain part of the investigation. During this very summer of 1838, therefore, while Agassiz was tracing the ancient limits of the ice in the Bernese Oberland and the Haut Valais, and later, in the valley of Chamounix, Guyot was studying the structure and movement of the ice during a six weeks' tour in the central Alps. At the conclusion of their respective joumeys they met to compare notes, at the session of the Geological Society of France, at Porrentruy, where Agassiz made a report upon the general results of his summer's work; while Guyot 
read a paper, the contents of which have never been fully published, upon the movement of glaciers and upon their internal features, including the laminated structure of the ice, the so-called blue bands, deep down in the mass of the glacier. ${ }^{1}$ In the succeeding years of their glacial researches together, Guyot took for his share the more special geological problems, the distribution of erratic boulders and of the glacial drift, as connected with the ancient extension of the glaciers. This led him away from the central station of observation to remoter valleys on the northern and southern slopes of the Alps, where he followed the descent of the glacial phenomena to the plains of central Europe on the one side and to those of northern Italy on the other. We therefore seldom hear of him with the band of workers who finally settled on the glacier of the Aar, because his share of the undertaking became a more isolated one. It was nevertheless an integral part of the original scheme, which was carried on connectedly to the end, the results of the work in the different departments being constantly reported and compared. So much was this the case, that the intention of Agas-

1 See Memoir of Louis Agassiz, by Arnold Guyot, written for the United States National Academy of Sciences, p. 38. 
siz had been to embody the whole in a publication, the first part of which should contain the glacial system of Agassiz; the second the Alpine erratics, by Guyot; while the third and final portion, by E. Desor, should treat of the erratic phenomena outside of Switzerland. The first volume alone was completed. Unlooked for circumstances made the continuation of the work impossible, and the five thousand specimens of the erratic rocks of Switzerland collected by Professor Guyot, in preparation for his part of the publication, are now deposited in the College of New Jersey, at Princeton.

In the following summer of 1839 Agassiz took the chain of Monte Rosa and Matterhorn as the field of a larger and more systematic observation. On this occasion, the usual party consisting of Agassiz, Desor, M. Bettanier, an artist, and two or three other friends, was joined by the geologist Studer. Up to this time he had been a powerful opponent of Agassiz's views, and his conversion to the glacial theory during this excursion was looked upon by them all as a victory greater than any gained over the regions of ice and snow. Some account of this journey occurs in the following letter. 
LOUIS AGASSIZ TO SIR PHILIP EGERTON.

NeUChâtel, September 10, 1839.

Under these circumstances, I thought I could not do better than to pass some weeks in the solitude of the high Alps; I lived about a fortnight in the region of the glaciers, ascending some new field of ice every day, and trying to scale the sides of our highest peaks. I thus examined in succession all the glaciers descending from the majestic summits of Monte Rosa and the Matterhorn, whose numerous crests form a most gigantic amphitheatre, which lifts itself above the everlasting snow. Afterward I visited the sea of ice which, under the name of the glacier of Aletsch, flows from the Jungfrau, the Mönch, and the Eiger toward Brieg; thence I went to the glacier of the Rhône, and from there, establishing my headquarters at the Hospice of the Grimsel, I followed the glacier of the Aar to the foot of the Finsteraarhorn. There I ascertained the most important fact that I now know concerning the advance of glaciers, namely, that the cabin constructed by Hugi in 1827, at the foot of the Abschwung, is now four thousand feet lower down. Slight as is the inclination of the glacier, this 
cabin has been carried on by the ice with as. tonishing rapidity, and still more important is it that this rapidity has been on the increase; for in 1830 the cabin was only some hundred feet from the rock, in 1836 it had already passed over a distance from [word torn away] of two thousand feet, and in the last three years it has again doubled that distance. Not only have I confirmed my views upon glaciers and their attendant phenomena, on this new ground, but I have completed my examination of a number of details, and have had besides the satisfaction of convincing one of my most severe opponents of the exactness of my observations, namely, M. Studer, who accompanied me on a part of these excursions. ...

The winter of 1840 was fully occupied by the preparation for the publication of the "Etudes sur les Glaciers," which appeared before the year was out, accompanied by an atlas of thirty-two plates. The volume of text consisted of an historical résumé of all that had previously been done in the study of glaciers, followed by an account of the observations of Agassiz and his companions during the last three or four years upon the glaciers of the Alps. Their structure, external aspect, 
needles, tables, perched blocks, gravel cones, rifts, and crevasses, as well as their movements, mode of formation, and internal temperature, were treated in succession. But the most interesting chapters, from the author's own point of view, and those which were most novel for his readers, were the concluding ones upon the ancient extension of the Swiss glaciers, and upon the former existence of an immense, unbroken sheet of ice, which had once covered the whole northern hemisphere. No one before had drawn such vast conclusions from the local phenomena of the Alpine valleys. "The surface of Europe," says Agassiz, "adorned before by a tropical vegetation and inhabited by troops of large elephants, enormous hippopotami, and gigantic carnivora, was suddenly buried under a vast mantle of ice, covering alike plains, lakes, seas and plateaus. Upon the life and movement of a powerful creation fell the silence of death. Springs paused, rivers ceased to flow, the rays of the sun, rising upon this frozen shore (if, indeed, it was reached by them), were met only by the breath of the winter from the north and the thunders of the crevasses as they opened across the surface of this icy sea." 1 The author goes on to state that on 1 Études sur les Glaciers. Chapter xviii. p. 315. 
the breaking up of this universal shroud the ice must have lingered longest in mountainous strongholds, and that all these fastnesses of retreat became, as the Alps are now, centres of distribution for the broken débris and rocky fragments which are found scattered with a kind of regularity along certain lines, and over given areas in northern and central Europe. How he followed out this idea in his subsequent investigations will be seen hereafter. 


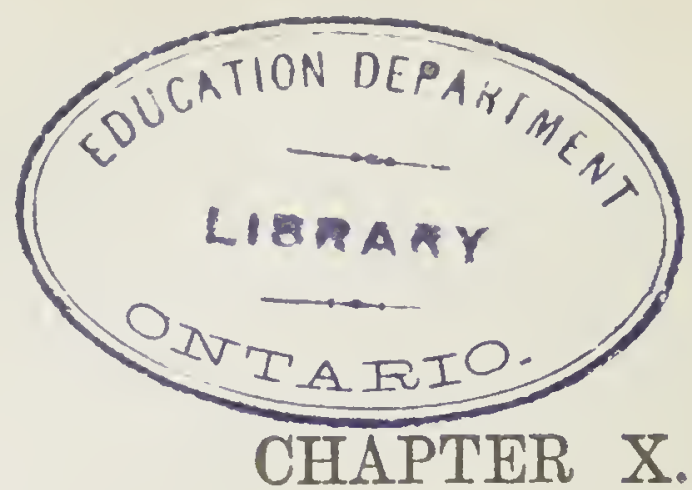

1840-1842 : ÆT. 33-35.

Summer Station on the Glacier of the Aar. - Hôtel des Neuchâtelois. - Members of the Party. - Work on the Glacier. - Ascent of the Strahleck and the Siedelhorn. Visit to England. - Search for Glacial Remains in Great Britain. - Roads of Glen Roy. - Views of English Naturalists concerning Agassiz's Glacial Theory. - Letter from Humboldt. - Winter Visit to Glacier. - Summer of 1841 ou the Glacier. - Descent into the Glacier. - Ascent of the Jungfrau.

IN the summer of 1840 Agassiz made his first permanent station on the Alps. Hitherto the external phenomena, the relation of the ice to its surroundings, and its influence upon them, had been the chief study. Now the glacier itself was to be the main subject of investigation, and he took with him a variety of instruments for testing temperatures : barometers, thermometers, hygrometers, and psychometers; beside a boring apparatus, by means of which self-registering thermometers might be lowered into the heart of the glacier. To these were added microscopes for the study of 
such insects and plants as might be found in these ice-bound regions. The Hospice of the Grimsel was selected as his base of supplies, and as guides Jacob Leuthold and Johann Währen were chosen. Both of these had accompanied Hugi in his ascension of the Finsteraarhorn in 1828, and both were therefore thoroughly familiar with all the dangers of Alpine climbing. The lower Aar glacier was to be the scene of their continuous work, and the centre from which their ascents of the neighboring summits would be made. Here, on the great median moraine, stood a huge boulder of micaceous schist. Its upper surface projected so as to form a roof, and by closing it in on one side with a stone wall, leveling the floor by a judicious arrangement of flat slabs, and rigging a blanket in front to serve as a curtain across the entrance, the whole was presently transformed into a rude hut, where six persons could find sleepingroom. A recess, sheltered by the rock outside, served as kitchen and dining-room; while an empty space. under another large boulder was utilized as a cellar for the keeping of provisions. This was the abode so.well known afterward as the Hôtel des Neuchâtelois. Its first occupants were Louis Agassiz, Edouard 
Desor, Charles Vogt, François de Pourtalès, Célestin Nicolet, and Henri Coulon. It afforded, perhaps, as good a shelter as they could have found in the old cabin of Hugi, where they had hoped to make their temporary home. In this they were disappointed, for the cabin had crumbled on its last glacial journey. The wreck was lying two hundred feet below the spot where they had seen the walls still standing the year before.

The work was at once distributed among the different members of the party, - Agassiz himself, assisted by his young friend and favorite pupil, François de Pourtalès, retaining for his own share the meteorological observations, and especially those upon the internal temperature of the glaciers. ${ }^{1}$ To M. Vogt fell the microscopic study of the red snow and the organic life contained in it; to $\mathrm{M}$. Nicolet, the flora of the glaciers and the surrounding rocks; to M. Desor, the glacial phenomena proper, including those of the moraines. He had the companionship and assist-

1 See "Tables of Temperature, Measurements," etc., in Agassiz's Système Glaciaire. These results are also recorded in a volume entitled Séjours dans les Glaciers, by Edonard Desor, a collection of very bright and entertaining articles upon the excursions and sojourns made in the Alps, during successive summers, by Agassiz and his scientific staff. 
ance of M. Henri Coulon in the long and laborious excursions required for this part of the work.

This is not the place for scientific details. For the results of Agassiz's researches on the Alpine glaciers, to which he devoted much of his time and energy during ten years, from 1836 to 1846 , the reader is referred to his two larger works on this subject, the "Etudes sur les Glaciers," and the "Système Glaciaire." Of the work accomplished by him and his companions during these years this slight summary is given by his friend Guyot." "The position of eighteen of the most prominent rocks on the glacier was determined by careful triangulation by a skillful engineer, and measured year after year to establish the rate of motion of every part. The differences in the rate of motion in the upper and lower part of the glacier, as well as in different seasons of the year, was ascertained; the amount of the annual melting was computed, and all the phenomena connected with it studied. All the surrounding peaks, - the Jungfrau, the Schreckhorn, the Finsteraarhorn, most of them

1 See Biographical Sketch, published by Professor A. Guyot, under the auspices of the United States National Academy. 
until then reputed unscalable, - were ascended, and the limit of glacial action discovered; in short all the physical laws of the glacier were brought to light."

We now return to the personal narrative. After a number of days spent in the study of the local phenomena, the band of workers turned their attention to the second part of their programme, namely, the ascent of the Strahleck, by crossing which and descending on the other side, they intended to reach Grindelwald. One morning, then, toward the end of August, their guides, according to agreement, aroused them at three o'clock, - an hour earlier than their usual roll-call. The first glance outside spread a general chill of disappointment over the party, for they found themselves beleaguered by a wall of fog on every side. But Leuthold, as he lighted the fire and prepared breakfast, bade them not despair, - the sun might make all right. In a few moments, one by one, the summits of the Schreckhorn, the Finsteraarhorn, the Oberaarhorn, the Altmaner, the Scheuchzerhorn, lighted by the first rays of the sun, came out like islands above the ocean of mist, which softly broke away and vanished with the advancing light. In about three hours they 
reached the base of the Strahleck. Their two guides, Leuthold and Währen, had engaged three additional men for this excursion, so that they now had five guides, none of whom were superfluous, since they carried with them various barometric instruments which required careful handling. They began the ascent in single file, but the slopes soon became so steep and the light snow (in which they floundered to the knees at every step) so deep, that the guides resorted to the usual method in such cases of tying them all together. The two head guides alone, Leuthold and Währen, remained detached, clearing the snow in front of them, cutting steps in the ice, and giving warning, by cry and gesture, of any hidden danger in the path. At nine o'clock, after an hour's climbing, they stepped upon the small plateau, evenly covered with unbroken snow, formed by the summit of the Strahleck.

The day had proved magnificent. With a clear sky above them, they looked down upon the valley of Grindelwald at their feet, while around and below them gathered the Scheideck and the Faulhorn, the pyramidal outline of the Niesen, and the chain of the Stockhorn. In front lay the great masses of the Eiger and the Mönch, while to the southwest 
the Jungfrau rose above the long chain of the Viescherhörner. The first pause of silent wonder and delight, while they released themselves from their cords and arranged their instruments, seems to have been succeeded by an outburst of spirits; for in the journal of the youngest of the party, François de Pourtalès, then a lad of seventeen, we read: "The guides began to wrestle and we to dance, when suddenly we saw a female chamois, followed by her young, ascending a neighboring slope, and presently four or five more stretched their necks over a rock, as if to see what was going on. Breathless the wrestlers and the dancers paused, fearing to disturb by the slightest movement creatures so shy of human approach. They drew nearer until within easy gunshot distance, and then galloping along the opposite ridge disappeared over the summit."

The party passed more than an hour on the top of the Strahleck, making observations and taking measurements. Then having rested and broken their fast with such provisions as they had brought, they prepared for a descent, which proved the more rapid, since much of it was a long slide. Tied together once more, they slid, wherever they found it possible to exchange the painful and difficult walling 


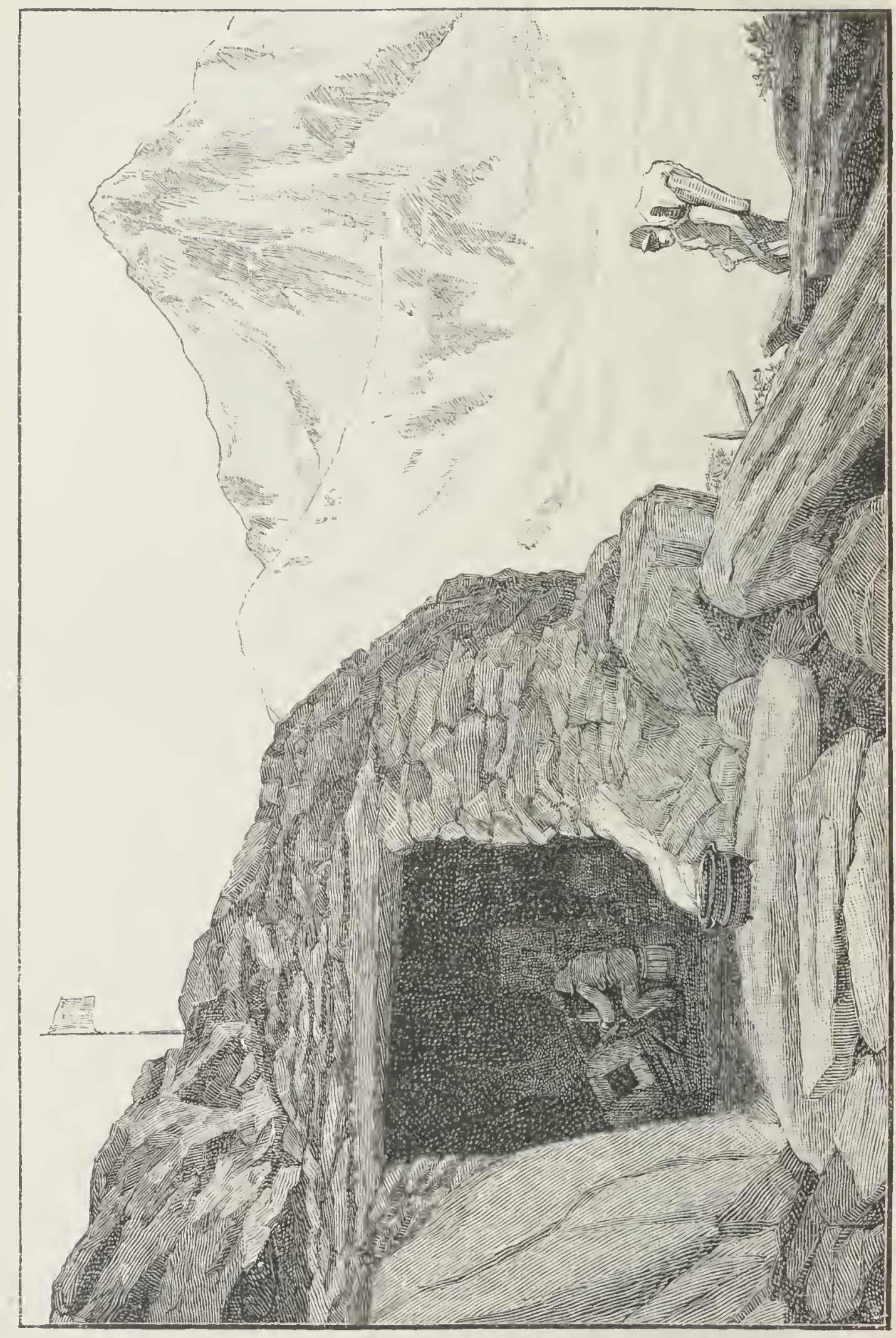

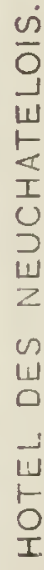


for this simpler process. "Once below these slopes of snow," says the journal of young de Pourtalès again, "rocks almost vertical, or narrow ledges covered with grass, served us as a road and brought us to the glacier of the Grindelwald. To reach the glacier itself we traversed a crevasse of great depth, and some twenty feet wide, on a bridge of ice, one or two feet in width, and broken toward the end, where we were obliged to spring across. Once on the glacier the rest was nothing. The race was to the fastest, and we were soon on the path of the tourists." Reaching the village of Grindelwald at three o'clock in the afternoon, they found it difficult to persuade the people at the inn that they had left the glacier of the Aar that morning. From Grindelwald they returned by the Scheideck to the Grimsel, visiting on their way the upper glacier of Grindelwald, the glacier of Schwartzwald, and that of Rosenlaui, in order to see how far these had advanced since their last visit to them. After a short rest at the Hospice of the Grimsel, Agassiz returned with two or three of his companions to their hut on the Aar glacier for the purpose of driving stakes into the holes previously bored in the ice. He hoped by means of these stakes to learn the followvoL. I. 
ing year what had been the rate of movement of the glacier. The summer's work closed with the ascent of the Siedelhorn. In all these ascents, the utmost pains was taken to ascertain how far the action of the ice might be traced upon these mountain peaks and the limits determined at which the polished surfaces ceased, giving place to the rough, angular rock which had never been modeled by the ice.

Agassiz had hardly returned from the Alps when he started for England. He had long believed that the Highlands of Scotland, the hilly Lake Country of England, and the mountains of Wales and Ireland, would present the same phenomena as the valleys of the Alps. Dr. Buckland had offered to be his guide in this search after glacier tracks, as he had formerly been in the hunt after fossil fishes in Great Britain. When, therefore, the meeting of the British Association at Glasgow, at which they were both present, was over, they started together for the Highlands. In a lecture delivered by Agassiz, at his summer school at Penikese, a few months before his death, he recurred to this journey with the enthusiasm of a young man. Recalling the scientific isolation in which he then stood, op- 
posed as he was to all the prominent geologists of the day, he said: "Among the older naturalists, only one stood by me. Dr. Buckland, Dean of Westminster, who had come to Switzerland at my urgent request for the express purpose of seeing my evidence, and who had been fully convinced of the ancient extension of ice there, consented to accompany me on my glacier hunt in Great Britain. We went first to the Highlands of Scotland, and it is one of the delightful recollections of my life that as we approached the castle of the Duke of Argyll, standing in a valley not unlike some of the Swiss valleys, I said to Buckland: "Here we shall find our first traces of glaciers;' and, as the stage entered the valley, we actually drove over an ancient terminal moraine, which spanned the opening of the valley." In short, Agassiz found, as he had anticipated, that in the mountains of Scotland, Wales, and the north of England, the valleys were in many instances traversed by terminal moraines and bordered by lateral ones, as in Switzerland. Nor were any of the accompanying phenomena wanting. The characteristic traces left by the ice, as well known to him now as the track of the game to the hunter; the peculiar lines, furrows, 
and grooves; the polished surfaces, the roches moutonnées; the rocks, whether hard or soft, cut to one level, as by a rigid instrument; the unstratified drift and the distribution of loose material in relation to the ancient glacierbeds, - all agreed with what he already knew of glacial action. $\mathrm{He}$ visited the famous "roads of Glen Roy" in the Grampian Hills, where so many geologists had broken a lance in defense of their theories of subsidence and upheaval, of ancient ocean-levels and seabeaches, formed at a time when they believed Glen Roy and the adjoining valleys to have been so many fiords and estuaries. To Agassiz, these parallel terraces explained themselves as the shores of a glacial lake, held back in its bed for a time by neighboring glaciers descending from more sheltered valleys. The terraces marked the successively lower levels at which the water stood, as these barriers yielded, and allowed its gradual escape. ${ }^{1}$ The glacial action in the whole neighborhood was such as to leave no doubt in the mind of

1 For details, see a paper by Agassiz on "The Glacial Theory and its Recent Progress" in the Edinburgh New Philosophical Journal, October, 1842, accompanied by a map of the Glen Roy region, and also an article entitled "Parallel Roads of Glen Roy, in Scotland," in the second volume of Agassiz's Geological Sketches. 
Agassiz that Glen Roy and the adjoining glens, or valleys, had been the drainage-bed for the many glaciers formerly occupying the western ranges of the Grampian Hills. He returned from his tour satisfied that the moun- tainous districts of Great Britain had all been centres of glacial distribution, and that the drift material and the erratic boulders, scattered over the whole country, were due to exactly the same causes as the like phenomena in Switzerland. On the 4th of November, 1840, he read a paper before the Geological Society of London, giving a summary of the scientific results of their excursion, followed by one from Dr. Buckland, who had become an ardent convert to his views. Apropos of this meeting, Dr. Buckland writes in advance as follows:-

Taymouth Castle, October $15,1840$.

... Lyell has adopted your theory in toto!!! On my showing him a beautiful cluster of moraines, within two miles of his father's house, he instantly accepted it, as solving a host of difficulties that have all his life embarrassed him. And not these only, but similar moraines and detritus of moraines, that cover half of the adjoining counties are 
explicable on your theory, and he has consented to my proposal that he should immediately lay them all down on a map of the county and describe them in a paper to be read the day after yours at the Geological Society. I propose to give in my adhesion by reading, the same day with yours, as a sequel to your paper, a list of localities where I have observed similar glacial detritus in Scotland, since I left you, and in various parts of England.

There are great reefs of gravel in the limestone valleys of the central bog district of Ireland. They have a distinct name, which I forget. No doubt they are moraines; if you have not, ere you get this, seen one of them, pray do so. ${ }^{1}$ But it wili not be worth while to go out of your way to see more than one; all the rest must follow as a corollary. I trust you will not fail to be at Edinboro' on the 20th, and at Sir W. Trevelyan's on the 24 th. ...

A letter of later date in the same month

1 Agassiz was then staying at Florence Court, the seat of the Earl of Enniskillen, in County Fermanagh, Ireland. While there he had an opportunity of studying most interesting glacial phenomena. 
LETTER TO SIR PHILIP EGERTON. 311

shows that Agassiz felt his views to be slowly gaining ground among his English friends.

LOUIS AGASSIZ TO SIR PHILIP EGERTON.

London, November 24, 1840.

... Our meeting on Wednesday passed off very well; none of my facts were disturbed, though Whewell and Murchison attempted an opposition; but as their objections were far-fetched, they did not produce much effect. I was, however, delighted to have some appearance of serious opposition, because it gave me a chance to insist upon the exactness of my observations, and upon the want of solidity in the objections brought against them. Dr. Buckland was truly eloquent. He has now full possession of this subject; is, indeed, completely master of it.

I am happy to tell you that everything is definitely arranged with Lord Francis, ${ }^{1}$ and that I now feel within myself a courage which doubles my strength. I have just written to thank him. To-morrow I shall devote to the fossils sent me by Lord Enniskillen, a list of which I will forward to you. . . .

${ }^{1}$ Apropos of the sale of his original drawings of fossil fishes to Lord Francis Egerton. 
We append here, a little out of the regular course, a letter from Humboldt, which shows that he too was begining to look more leniently upon Agassiz's glacial conclusions.

HUMBOLDT TO LOUIS AGASSIZ.

Berlin, August 15, 1840.

I am the most guilty of mortals, my dear friend. There are not three persons in the world whose remembrance and affection I value more than yours, or for whom I have a warmer love and admiration, and yet I allow half the year to pass without giving you a sign of life, without any expression of my warm gratitude for the magnificent gifts I owe to you. ${ }^{1}$

I am a little like my republican friend who no longer answers any letters because he does not know where to begin. I receive on an average fifteen hundred letters a year. I never dictate. I hold that resort in horror. How dictate a letter to a scholar for whom one has a real regard? I allow myself to be drawn into answering the persons I know least, whose wrath is the most menacing. My nearer friends (and none are more dear to me

1 Probably the plates of the Fresh-Water Fishes and other illustrated prolications. 
than yourself) suffer from my silence. I count with reason upon their indulgence. The tone of your excellent letters shows that I am right. You spoil me. Your letters continue to be always warm and affectionate. I receive few like them. Since two thirds of the letter's addressed to me (partly copies of letters written to the king or the ministers) remain unanswered, I am blamed, charged with being a parvenu courtier, an apostate from science. This bitterness of individual claims does not diminish my ardent desire to be useful. I act - oftener than I answer. I know that I like to do good, and this consciousness gives me tranquillity in spite of my over burdened life. You are happy, my dear Agassiz, in the more simple and yet truly proud position which you have created for yourself. You ought to take satisfaction in it as the father of a family, as an illustrious savant, as the originator and source of so many new ideas, of so many great and noble conceptions.

Your admirable work on the fossil fishes draws to a close. The last number, so rich in discoveries, and the prospectus, explaining the true state of this vast publication, have soothed all irritation regarding it. It is because $I$ am so attached to you that I rejoice in the calmer 
atmosphere you have thus established about you. The approaching completion of the fossil fishes delivers me also from the fear that a too great ardor might cause you irreparable losses. You have shown not only what a talent like yours can accomplish, but also how a noble courage can triumph over seemingly insurmountable obstacles.

In what words shall I tell you how greatly our admiration is increased by this new work of yours on the Fresh-Water Fishes? Nothing has appeared more admirable, more perfect in drawing and color. This chromatic lithography resembles nothing we have had thus far. What taste has directed the publication! Then the short descriptions accompanying each plate add singularly to the charm and the enjoyment of this kind of study. Accept my warm thanks, my dear friend. I not only delivered your letter and the copy with it to the king, but I added a short note on the merit of such an undertaking. The counselor of the Royal Cabinet writes me officially that the king has ordered the same number of copies of the Fresh-Water Fishes as of the Fossil Fishes; that is to say, ten copies. M. de Werther has already received the order. This is, to be sure, but a slight help; still, 
it is all that I have been able to obtain, and these few copies, with the king's name as subscriber, will always be useful to you.

I cannot close this letter without asking your pardon for some expressions, too sharp, perhaps, in my former letters, about your vast geological conceptions. The very exaggeration of my expressions must have shown you how little weight I attached to my objections. .... My desire is always to listen and to learn. Taught from my youth to believe that the organization of past times was somewhat tropical in character, and startled therefore at these glacial interruptions, I cried "Heresy!" at first. But should we not always listen to a friendly voice like yours? I am interested in whatever is printed on these topics; so, if you have published anything at all complete lately on the ensemble of your geological ideas, have the great kindness to send it to me through a book-seller. ...

Shall I tell you anything of my own poor and superannuated works? The sixth volume is wanting to my "Geography of the Fifteenth Century" (Examen Critique). It will appear this summer. I am also printing the second volume of a new work to be entitled "Central Asia." It is not a second edition of "Asiatic 
Fragments," but a new and wholly different work. The thirty-five sheets of the last volume are printed, but the two volumes will only be issued together. You can judge of the difficulty of printing at Paris and correcting proofs here, - at Poretz or at Töplitz. I am just now beginning to print the first number of my physics of the world, under the title of "Cosmos:" in German, "Ideen zur einer physischen Weltbeschreibung." It is in no sense a reproduction of the lectures I gave here. The subject is the same, but the presentation does not at all recall the form of a popular course. As a book, it has a somewhat graver and more elevated style. A "spoken book" is always a poor book, just as lectures read are poor however well prepared. Published courses of lectures are my detestation. Cotta is also printing a volume of mine in German, "Physikalische geographische Erinnerungen." Many unpublished things concerning the volcanoes of the Andes, about currents, etc. And all this at the age when one begins to petrify! It is very rash! May this letter prove to you and to Madame Agassiz that I am petrifying only at the extremities, - the heart is still warm. Retain for me the affection which I hold so dear. 
In the following winter, or, rather, in the early days of March, 1841, Agassiz visited, in company with M. Desor, the glacier of the Aar and that of Rosenlaui. He wished to examine the stakes planted the summer before on the glacier of the Aar, and to compare the winter and summer temperature within as well as without the mass of ice. But his chief object was to ascertain whether water still flowed from beneath the glaciers during the frosts of winter. This fact would have a direct bearing upon the theory which referred the melting and movement of the glaciers chiefly to their lower surface, explaining them by the central heat of the earth as their main cause. Satisfied as he was of the fallacy of this notion, Agassiz still wished to have the evidence of the glacier itself. The journey was, of course, a difficult one at such a season, but the weather was beautiful, and they accomplished it in safety, though not "without much suffering. They found no water except the pure and limpid water from springs that never freeze. The glacier lay dead in the grasp of winter. The results of this journey, tables of temperature, etc., are recorded in the "Système Glaciaire."

In E. Desor's "Séjours dans les Glaciers" 
is found an interesting description of the incidents of this excursion and the appearance of the glaciers in winter. In ascending the course of the Aar they frequently crossed the shrunken river on natural snow bridges, and approaching the Handeck over fearfully steep slopes of snow they had some difficulty in finding the thread of water which was all that remained of the beautiful summer cascade. On the glacier of the Aar they found the Hôtel des Neuchâtelois buried in snow, while the whole surface of the glacier as well as the surrounding peaks, from base to summit, wore the same spotless mantle. The Finsteraarhorn alone stood out in bold relief, black against a white world, its abrupt slopes affording no foothold for the snow. The scene was far more monotonous than in summer. Crevasses, with their blue depths of ice, were closed; the many-voiced streams were still; the moraines and boulders were only here and there visible through the universal shroud. The sky was without a cloud, the air transparent, but the glitter of the uniform white surface was exquisitely painful to the eyes and skin, and the travelers were obliged to wrap their heads in double veils. They found the glacier of Rosenlaui less enveloped in 
snow than that of the Aar; and though the magnificent ice-cave, so well known to travelers for its azure tints, was inaccessible, they could look into the vault and see that the habitual bed of the torrent was dry. The journey was accomplished in a week without any untoward accident.

In the summer of 1841 Agassiz made a longer Alpine sojourn than ever before. The special objects of the season's work were the internal structure of these vast moving fields of ice, the essential conditions of their origin and continued existence, the action of water within them as influencing their movement, and their own agency in direct contact with the beds and walls of the valleys they occupied. The fact of their former extension and their present oscillations might be considered as established. It remained to explain these facts with reference to the conditions prevailing within the mass itself. In short, the investigation was passing from the domain of geology to that of physics. Agassiz, who was as he often said of himself no physicist, was the more anxious to have the coöperation of the ablest men in that department, and to share with them such facilities for observation and such results as he had thus far accumu- 
lated. In addition to his usual collaborators, M. Desor and M. Vogt, he had, therefore, invited as his guest, during part of the season, the distinguished physicist, Professor James D. Forbes, of Edinburgh, who brought with him his friend, Mr. Heath, of Cambridge. ${ }^{1}$ M. Escher de la Linth took also an active part in the work of the later summer. To his working corps Agassiz had added the foreman of M. Kahli, an engineer at Bienne, to whom he had confided his plans for the summer, and who furnished him with a skilled workman to direct the boring operations, assist in measurements, etc. The artist of this year was $\mathbf{M}$. Jaques Burkhardt, a personal friend of Agassiz, and his fellow-student at Munich, where he had spent some time at the school of art. As a draughtsman he was subsequently associated with Agassiz in his work at various times, and when they both settled in America Mr. Burkhardt became a permanent member of Agassiz's household, accompanied him on his journeys, and remained with him in relations of uninterrupted and affectionate regard till his own death in 1867. He was a loyal friend

1 As the impressions of Mr. Forbes were only made known in connection with his own later and independent researehes it is unnecessary to refer to them here. 
- and a warm-hearted man, with a thread of humor running through his dry good sense, which made him a very amusing and attractive companion.

As it was necessary, in view of his special programme of work, to penetrate below the surface of the glacier, and reach, if possible, its point of contact with the valley bottom, Agassiz had caused a larger boring apparatus than had been used before, to be transported to the old site on the Aar glacier. The results of these experiments are incorporated in the "Système Glaciaire," published in 1846, with twenty-four folio plates and two maps. They were of the highest interest with reference to the internal structure and temperature of the ice and the penetrability of its mass, pervious throughout, as it proved, to air and water. On one occasion the boring-rod, having been driven to a depth of one hundred and ten feet, dropped suddenly two feet lower, showing that it had passed through an open space hidden in the depth of the ice. The release of air-bubbles at the same time gave evidence that this glacial cave, so suddenly broken in upon, was not hermetically sealed to atmospheric influences from without.

VOL. I. 
Agassiz was not satisfied with the report of his instruments from these unknown regions. He determined to be lowered into one of the so-called wells in the glacier, and thus to visit its interior in person. For this purpose he was obliged to turn aside the stream which flowed into the well into a new bed which he caused to be dug for it. This done, he had a strong tripod erected over the opening, and, seated upon a board firmly attached by ropes, he was then let down into the well, his friend Escher lying flat on the edge of the precipice, to direct the descent and listen for any warning cry. Agassiz especially desired to ascertain how far the laminated or ribboned structure of the ice (the so-called blue bands) penetrated the mass of the glacier. This feature of the glacier had been observed and described by M. Guyot (see p. 292), but Mr. Forbes had called especial attention to it, as in his belief connected with the internal conditions of the glacier. It was agreed, as Agassiz bade farewell to his friends on this curious voyage of discovery, that he should be allowed to descend until he called out that they were to lift him. He was lowered successfully and without accident to a depth of eighty feet. There he encountered 
an unforeseen difficulty in a wall of ice which divided the well into two compartments. He tried first the larger one, but finding it split again into several narrow tumnels, he caused himself to be raised sufficiently to enter the smaller, and again proceeded on his downward course without meeting any obstacle. Wholly engrossed in watching the blue bands, still visible in the glittering walls of ice, he was only aroused to the presence of approaching danger by the sudden plunge of his feet into water. His first shout of distress was misunderstood, and his friends lowered him into the ice-cold gulf instead of raising him. The second cry was effectual, and he was drawn up, though not without great difficulty, from a depth of one hundred and twenty-five feet. The most serious peril of the ascent was caused by the huge stalactites of ice, between the points of which he had to steer his way. Any one of them, if detached by the friction of the rope, might have caused his death. He afterward said: "Had I known all its dangers, perhaps I should not have started on such an adventure. Certainly, unless induced by some powerful scientific motive, I should not advise any one to follow my example." On this perilous journey he traced the laminated structure 
to a depth of eighty feet, and even beyond, though with less distinctness.

The summer closed with their famous ascent of the Jungfrau. The party consisted of twelve persons: Agassiz, Desor, Forbes, Heath, and two travelers who had begged to join them, - M. de Chatelier, of Nantes, and M. de Pury, of Neuchâtel, a former pupil of Agassiz. The other six were guides; four beside their old and tried friends, Jacob Leuthold and Johann Währen. They left the hospice of the Grimsel on the 27th of August, at four o'clock in the morning. Crossing the $\mathrm{Col}$ of the Oberaar they descended to the snowy plateau which feeds the Viescher glacier. In this grand amphitheatre, walled in by the peaks of the Viescherhörner, they rested for their midday meal. In crossing these fields of snow, while walking with perfect security upon what seemed a solid mass, they observed certain window-like openings in the snow. Stooping to examine one of them, they looked into an immense open space, filled with soft blue light. They were, in fact, walking on a hollow crust, and the small window was, as they afterward found, opposite a large crevasse on the other side of this icecavern, through which the light entered, flood- 
ing the whole vault and receiving from its icy walls its exquisite reflected color. ${ }^{1}$

Once across the fields of snow and névé, a fatiguing walk of five hours brought them to the chalets of Méril, ${ }^{2}$ where they expected to sleep. The night which should have prepared them for the fatigue of the next day was, however, disturbed by an untoward accident. The ladder left by Jacob Leuthold when last here with Hugi in 1832, nine years before, and upon which he depended, had been taken away by a peasant of Viesch. Two messengers were sent in the course of the night to the village to demand its restoration. The first returned unsuccessful; the second was the bearer of such threats of summary punishment from the whole party that he carried his point, and appeared at last with the recovered treasure on his back. They had, in the mean while, lost two hours. They should have been on their road at three o'clock; it was now five. Jacob warned them therefore that they must make all speed, and that any one who felt himself unequal to a forced

1 The effect is admirably described by M. Desor in his account of this excursion, Séjours dans les Glaciers, p. 367.

${ }^{2}$ Sometimes Möril, but $I$ have retained the spelling of $M$. Desor. - E. C. A. 
march should stay behind. No one responded to his suggestion, and they were presently on the road.

Passing Lake Méril, with its miniature icebergs, they reached the glacier of the Aletsch and its snow-fields, where the real difficulties and dangers of the ascent were to begin. In this great semicircular space, inclosed by the Jungfrau, the Mönch, and the lesser peaks of this mountain group, lies the Aletsch reservoir of snow or névé. As this spot presented a natural pause between the laborious ascent already accomplished and the immense declivities which lay before them yet to be climbed, they named it Le Repos, and halted there for a short rest. Here they left also every needless incumbrance, taking only a little bread and wine, in case of exhaustion, some meteorological instruments, and the inevitable ladder, axe, and ropes of the Alpine climber. On their left, to the west of the amphitheatre, a vast passage opened between the Jungfrau and the Kranzberg, and in this could be distinguished a series of terraces, one above the other. The story is the usual one, of more or less steep slopes, where they sank in the softer snow or cut their steps in the icy surfaces; of open crevasses, crossed by the lad- 
der, or the more dangerous ones, masked by snow, over which they trod cautiously, tied together by the rope. But there was nothing to appall the experienced mountaineer with firm foot and a steady head, until they reached a height where the summit of the Jungfrau detached itself in apparently inaccessible isolation from all beneath or around it. To all but the guides their farther advance seemed blocked by a chaos of precipices, either of snow and ice or of rock. Leuthold remained however quietly confident, telling them he clearly saw the course he meant to follow. It began by an open gulf of unknown depth, though not too wide to be spanned by their ladder twenty-three feet in length. On the other side of this crevasse, and immediately above it, rose an abrupt wall of icy snow. Up this wall Leuthold and another guide led the way, cutting steps as they went. When half way up they lowered the rope, holding one end, while their companions fastened the other to the ladder, so that it served them as a kind or hand-rail, by which to follow. At the top they found themselves on a terrace, beyond which a far more moderate slope led to the Col of Roththal, overlooking the Aletsch valley on one side, the Roththal on the other. 
From this point the ascent was more and more steep and very slow, as every step had to be cut. Their difficulties were increased, also, by a mist which gathered around them, and by the intense cold. Leuthold kept the party near the border of the ridge, because there the ice yielded more readily to the stroke of the axe; but it put their steadiness of nerve to the greatest test, by keeping the precipice constantly in view, except when hidden by the fog. Indeed, they could drive their alpenstocks through the overhanging rim of frozen snow, and look sheer down through the hole thus made to the amphitheatre below. One of the guides left them, unable longer to endure the sight of these precipices so close at hand. As they neared their goal they feared lest the mist might, at the last, deprive them of the culminating moment for which they had braved such dangers. But suddenly, as if touched by their perseverance, says M. Desor, the veil of fog lifted, and the summit of the Jungfrau, in its final solitude, rose before them. There was still a certain distance to be passed before they actually reached the base of the extreme peak. Here they paused, not without a certain hesitation, for though the summit lay but a few feet 


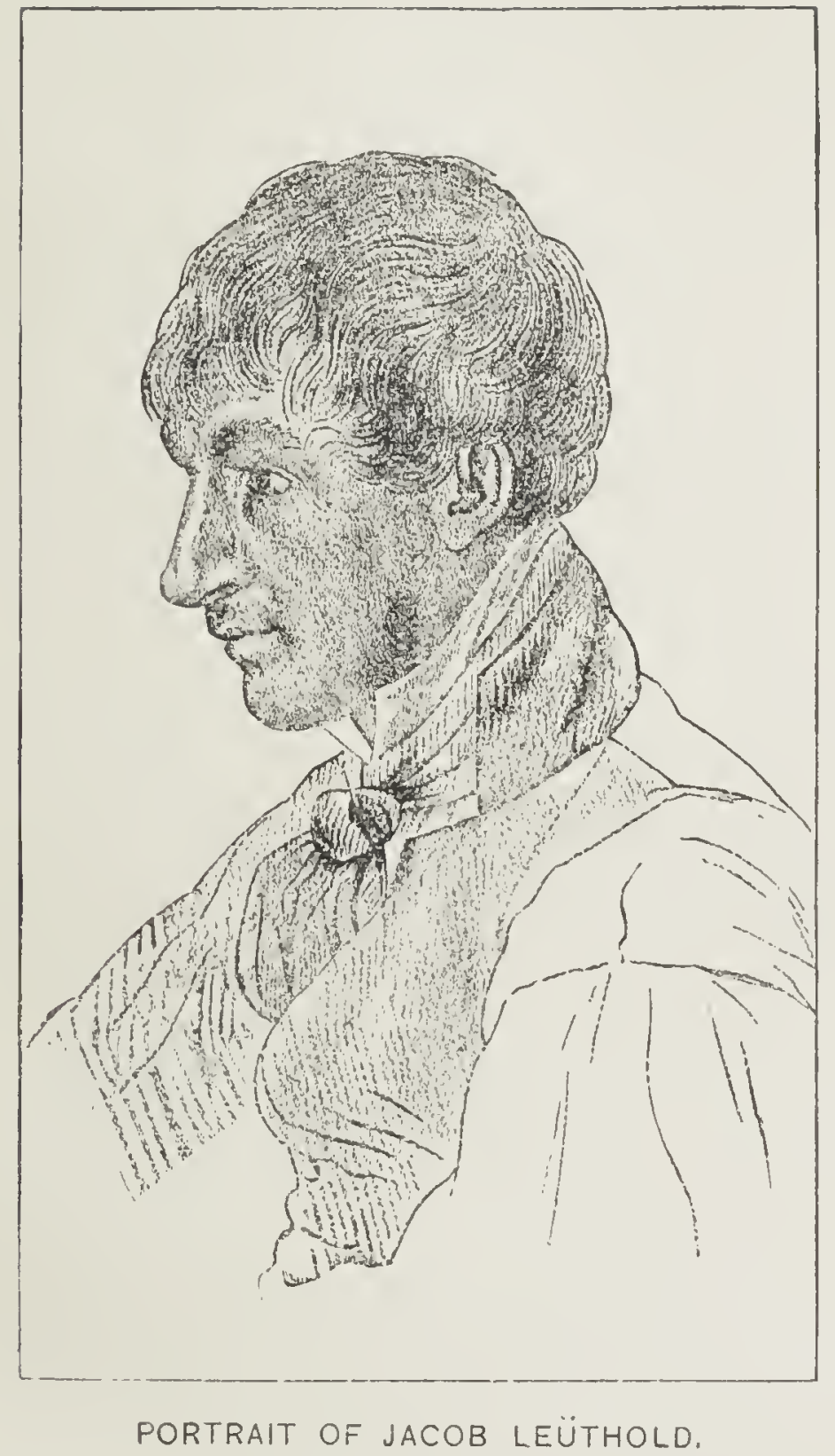

From a portrait by $\mathcal{F}$. Burlichardt. 

above them, they were separated from it by a sharp and seemingly inaccessible ridge. Even Agassiz, who was not easily discouraged, said, as he looked up at this highest point of the fortress they had scaled: "We can never reach it." For all answer, Jacob Leuthold, their intrepid guide, flinging down everything which could embarrass his movements, stretched his alpenstock over the ridge as a grappling pole, and, trampling the snow as he went, so as to flatten his giddy path for those who were to follow, was in a moment on the

- top. To so steep an apex does this famous peak narrow, that but one person can stand on the summit at a time, nor was even this possible till the snow was beaten down. Returning on his steps, Leuthold, whose quiet, unflinching audacity of success was contagious, assisted each one to stand for a few moments where he had stood. The fog, the effect of which they had so much feared, now lent something to the beauty of the view from - this sublime foothold. Masses of vapor rolled up from the Roththal on the southwest, but, instead of advancing to envelop them, paused at a little distance arrested by some current from the plain. The temperature being below freezing point, the drops of moisture in 
this wall of vapor were congealed into icecrystals, which glittered like gold in the sunlight and gave back all the colors of the rainbow.

When all the party were once more assembled at the base of the peak, Jacob, whose resources never failed, served to each one a little wine, and they rested on the snow before beginning their perilous descent. Of living things they saw only a hawk, poised in the air above their heads; of plants, a few lichens, where the surface of the rock was exposed. It was four o'clock in the afternoon before they started on their downward path, turning their faces to the icy slope, and feeling for the steps behind them, some seven hundred in all, which had been cut in ascending. In about an hour they reached the $\mathrm{Col}$ of the Roththal, where the greatest diffculties of the ascent had begun and the greatest dangers of the descent were over. So elated were they by the success of the day, and so regardless of lesser perils after those they had passed through, that they were now inclined to hurry forward incautiously. $\mathrm{Ja}^{-}$ cob, prudent when others were rash, as he was bold when others were intimidated, constantly called them to order with his: "Hüb- 
schle ! nur immer hübschle!" ("Gently! always gently!")

At six o'clock they were once more at Le Repos, having retraced their steps in two hours over a distance which had cost them six in going. Evening was now falling, but daylight was replaced by moonlight, and when they reached the glacier its whole surface shone with a soft silvery lustre, broken here and there by the gigantic shadow of some neighboring mountain thrown black across it. At about nine o'clock, just as they had passed that part of the glacier which was, on account of the frequent crevasses, the most dangerous, they were cheered by the sound of a distant jodel. It was the call of a peasant who had been charged to meet them with provisions, at a certain distance above Lake Méril, in case they should be overcome by hunger and fatigue. The most acceptable thing he brought was his great wooden bucket, filled with fresh mill. The picture of the party, as they stood around him in the moonlight, dipping eagerly into his bucket, and drinking in turn until they had exhausted the supply, is so vivid, that one shares their good spirits and their enjoyment. Thus refreshed, they started on the last stage of 
their journey, three leagues of which yet lay before them, and at half-past eleven arrived at the chalets of Méril, which they had left at dawn.

On the morrow the party broke up, and Agassiz and Desor, accompanied by their friend, M. Escher de la Linth, returned to the Grimsel, and after a day's rest there repaired once more to the Hôtel des Neuchâtelois. They remained on the glacier until the 5th of September, spending these few last days in completing their measurements, and in planting the lines of stakes across the glacier, to serve as a means of determining its rate of movement during the year, and the comparative rapidity of that movement at certain fixed points. Thus concluded one of the most eventful seasons Agassiz and his companions had yet passed upon the Alps. ${ }^{1}$

1 Though quoting his exact language only in certain instances, the account of this and other Alpine ascensions described above has been based upon M. E. Desor's Séjours dans les Glaciers. His very spirited narratives, added to my own recollections of what I had heard from Mr. Agassiz himself on the same subject, have given me my material. E. C. A. 


\section{CHAPTER XI.}

$1842-1843$ : ET. $35-36$.

Zoölogical Work uninterrupted by Glacial Researches. Various Publications. - "Nomenclator Zoölogicus." "Bibliographia Zoölogiæ et Greologiæ." - Correspondence with English Naturalists. - Correspondence with Humboldt. - Glacial Campaign of 1842. - Correspondence with Prince de Canino concerning Journey to United States. - Fossil Fishes from the Old Red Sandstone. - Glacial Campaign of 1843. - Death of Leuthold, the Guide.

Although his glacier work was now so prominent a feature of Agassiz's scientific life, his zoölogical studies, especially his ichthyological researches, and more especially his work on fossil fishes, went on with little interruption. His publications upon Fossil Mollusks, ${ }^{1}$ upon Tertiary Shells, ${ }^{2}$ upon Living and Fossil Echinoderms, ${ }^{3}$ with many smaller monographs on special subjects, were undertaken

1 Etudes Critiques sur les Mollusques Fossiles, 4 nos., 4, with 100 plates.

2 Iconographie des Coquilles Tertiaires réputées identiques sur les vivans, 1 no., $4^{\circ}, 14$ plates.

${ }^{8}$ Monographie d'Echinodermes vivans et fossiles, 4 nos., $4^{\circ}$, with 37 plates. 
and completed during the most active period of his glacial inrestigations. More surprising is it to find hirn, while pursuing new lines of investigation with passionate enthusiasm, engased at the sarne tirne upon works seemingly so) dry and tedirous as his "Nomenclator Zoostogricus," and his "Bibliographia Zoülogix et Geologrixe."

The former work, a large quarto volume with an Index, ${ }^{1}$ cromprised an enumeration of all the genera of the animal kingdom, with the etymology of their names, the names of throse who had first proprosed them, and the date of their publication. He obtained the corjperation of other naturalists, submitting ear:h class as far as prossitble for revision to the learders in their respective departments.

In his letter of presentation to the library of the Neuchatel Acarderny, addressed to M. le Paron de Chambrier, President of the Ac:ademic: Council, Agassiz thus describes the Nismerrelator.

"Have the kindness to aecept for the litwary of the Acadremy the fifth number of a work uporn the sources of zoridorgical criticissn, the putslication of which I have just begur. It is a work of patience, demanding

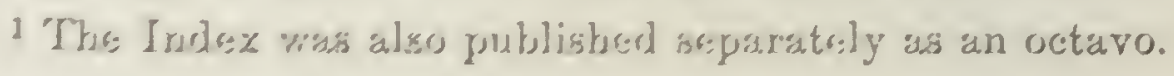


long and laborious researches. I had conceived the plan in the first years of my studies, and since then have never lost sight of it. I venture to believe it will be a barrier against the Babel of confusion which tends to orerwhelm the domain of zoölogical synonymy. My book will be called 'Nomenclator Zoölog'icus." ". . .

The Bibliographia ( 4 volumes, $\mathrm{S}^{\circ}$ ) was in some measure a complement of the Nomenclator, and contained a list of all the authors named in the latter, with notices of their works. It appeared somewhat later, and was published by the Ray Society in England, in 1848, after Agassiz had left Europe for the United States. The material for this work also had been growing upon his hands for years. Feeling more and more the importance of such a register as a guide for students, he appealed to naturalists in all parts of Europe for information upon the scientific bibliography of their respective countries, and at last succeeded in cataloguing, with such completeness as was possible, all known works and all scattered memoirs on zoölogy and geology. Unable to publish this costly but unremunerative material, he was delighted to 
give it up to the Ray Society. The first three volumes were edited with corrections and additions by Mr. H. E. Strickland, who died before the appearance of the fourth volume, which was finally completed under the care of his father-in-law, Sir William Jardine.

The ability, so eminently possessed by Agassiz of dealing with a number of subjects at once, was due to no superficial versatility. To him his work had but one meaning. It was never disconnected in his thought, and therefore he turned from his glaciers to his fossils, and from the fossil to the living world, with the feeling that he was always dealing with kindred problems, bound together by the same laws. Nowhere is this better seen than in the records of the scientific society of Neuchâtel, the society he helped to found in the first months of his professorship, and to which he always remained strongly attached, being a constant attendant at its sessions from 1833 to 1846 . Here we find him from month to month, with philosophic breadth of thought, treating of animals in their widest relations, or describing minute structural details with the skill of a specialist. He presents organized beings in their geological succession, in their 
geographical distribution, in their embryonic development. He reviews and remodels laws of classification. Sometimes he illustrates the fossil by the living world, sometimes he finds the key to present phenomena in the remote past. He reconstructs the history of the glacial period, and points to its final chapter in the nearest Alpine valleys, connecting these facts again with like phenomena in distant parts of the globe. But however wide his range and however various his topics, under his touch they are all akin, all coördinate parts of a whole which he strives to understand in its entirety. A few extracts from his correspondence will show him in his different lines of research at this time.

The following letter is from Edward Forbes, one of the earliest explorers of the deep-sea fauna. Agassiz had asked him for some help in his work upon echinoderms.

EDWARD FORBES TO LOUIS AGASSIZ.

21 Lothian St., Edrnburgh, February 13, 1841.

... A letter from you was to me one of the greatest of pleasures, and with great delight (though, I fear, imperfectly) I have executed the commission you gave me. It should have been done much sooner had not the vol. I. 
storms been so bad in the sea near this that, until three days ago, I was not able to procure a living sea-urchin from which to make the drawings required. . . Y You have made all the geologists glacier-mad here, and they are turning Great Britain into an ice-house. Some amusing and very absurd attempts at opposition to your views have been made by one or two pseudo-geologists; among others, poor - , who has read a paper at the Royal Society here, maintaining that all the appearances you refer to glaciers were caused by blocks of ice which floated this way in the Deluge! and that the fossils of the pleistocene strata were mollusks, etc., which, climbing upon the ice-blocks, were carried to warmer seas against their will!! To my mind, one of the best proofs of the truth of your views lies in the decidedly arctic character of the pleistocene fauna, which must be referred to the glacier time, and by such reference is easily understood. I mean during the summer to collect data on that point, in order to present a mass of geological proofs of your theory.

Dr. Traill tells me you are proposing to visit England again during the coming summer. If you do, I hope we shall meet, when I shall have many things to show you, which 
time did not permit when you were here. I look anxiously for the forth-coming number of your history of the Echinodermata. . . .

FROM SIR RODERICK MURCHISON.

June 13, 1842.

... Your letters have given me great pleasure: first, in assuring me that your zeal in ichthyology is undiminished, and that you are about to give such striking proofs of it to the British Association; and next that you still pursue with enthusiasm your admirable researches upon the glaciers. I should be charmed to put myself under your guidance for a walk on the glaciers of the Aar, but I hardly dare promise it yet. . . Even were I to make every haste, I doubt if it be possible to reach your Swiss meeting in time. It is just possible that I may find you in your glacial cantonment after your return, but even this will depend upon circumstances over which I have no control.

I send this letter to you by my friend, Admiral Sir Charles Malcolm, who passes through Neuchâtel on his way to Geneva. Accompanying it is a copy of my last discourse, which I request you to accept and to read all parts of it. You will see that I have grappled 
honestly and according to my own faith with your ice, but have never lost sight of your great merit. My concluding paragraph will convince you and all your friends that if I am wrong it is not from any preconceived notions, but only because I judge from what you will call incomplete evidence. Your "Venez voir!" still sounds in my ears. ...

Murchison remained for many years an opponent of the glacial theory in its larger application. In the discourse to which the above letter makes allusion (Address at the Anniversary Meeting of the Geological Society of London, $1842^{1}$ ) is this passage: "Once grant to Agassiz that his deepest valleys of Switzerland, such as the enormous Lake of Geneva, were formerly filled with snow and ice, and I see no stopping place. From that hypothesis you may proceed to fill the Baltic and the northern seas, cover southern England and half of Germany and Russia with similar icy sheets, on the surfaces of which all the northern boulders might have been shot off. So long as the greater number of the practical geologists of Europe are opposed to the wide extension of

I Extract from Report in vol. 33 of the Edinburgh New Philosophical Journal. 
a terrestrial glacial theory, there can be little risk that such a doctrine should take too deep a hold of the mind. . . . The existence of glaciers in Scotland and England (I mean in the Alpine sense) is not, at all events, established to the satisfaction of what I believe to be by far the greater number of British geologists."

Twenty years later, with rare candor, Murchison wrote to Agassiz as follows; by its connection, though not by its date, the extract is in place here: "I send you my last anniversary address, which I wrote entirely myself; and I beg you to believe that in the part of it that refers to the glacial period, and to Europe as it was geographically, I have had the sincerest pleasure in avowing that I was wrong in opposing as I did your grand and original - idea of my native mountains. Yes! I am now convinced that glaciers did descend from the mountains to the plains as they do now in Greenland."

During the summer of 1842, at about the same date with Murchison's letter disclaiming the glacial theory, Agassiz received, on the other hand, a new evidence, and one which must have given him especial pleasure, of the favorable impression his views were making in some quarters in England. 
FROM DR. BUCKLAND.

OXFORD, July 22, 1842.

...You will, I am sure, rejoice with me at the adhesion of $\mathrm{C}$. Darwin to the doctrine of ancient glaciers in North Wales, of which I send you a copy, and which was communicated to me by Dr. Tritten, during the late meeting at Manchester, in time to be quoted by me versus Murchison, when he was proclaiming the exclusive agency of floating icebergs in drifting erratic blocks and making scratched and polished surfaces. It has raised the glacial theory fifty per cent., as far as relates to glaciers descending inclined valleys; but Hopkins and the Cantabrigians are still as obstinate as ever against allowing the power of expansion to move ice along great distances on horizontal surfaces. . . .

The following is the letter referred to above.

C. DARWIN TO DR. TRITTEN.

Yesterday (and the previous days) I had some most interesting work in examining the marks left by extinct glaciers. I assure you, an extinct volcano could hardly leave more evident traces of its activity and vast powers. 
I found one with the lateral moraine quite perfect, which Dr. Buckland did not see. Pray if you have any communication with Dr. Buckland give him my warmest thanks for having guided me, through the published abstract of his memoir, to scenes, and made me understand them, which have given me more delight than I almost remember to have experienced since I first saw an extinct crater. The valley about here and the site of the inn at which I am now writing must once have been - covered by at least 800 or 1,000 feet in thickness of solid ice! Eleven years ago I spent a whole day in the valley where yesterday everything but the ice of the glaciers was palpably clear to me, and I then saw nothing but plain water and bare rock. These glaciers have been grand agencies. I am the more pleased with what $I$ have seen in North Wales, as it convinces me that my view of the distribution of the boulders on the South American plains, as effected by floating ice, is correct. I am also more convinced that the valleys of Glen Roy and the neighboring parts of Scotland have been occupied by arms of the sea, and very likely (for in that point I cannot, of course, doubt Agassiz and Buckland) by glaciers also. 
It continued to be a grief to Agassiz that Humboldt, the oldest of all his scientific friends, and the one whose opinion he most reverenced, still remained incredulous. Humboldt's letters show that Agassiz did not willingly renounce the hope of making him a convert. Agassiz's own letters to Humboldt are missing from this time onward. Overwhelmed with occupation, and more at his ease in his relations with the older scientific men, he had ceased to make the rough drafts in which his earlier correspondence is recorded.

\section{HUMBOLDT TO AGASSIZ.}

BerLin, March 2, 1842.

. . When one has been so long separated, even accidentally, from a friend as I have been from you, my dear Agassiz, it is difficult to find beginning or end to a letter. The kindly remembrance which you send me is evidence that my long silence has not seemed strange to you. .. . It would be wasting words to tell you how I have been prevented, by the distractions of my life, always increasing with old age, from acknowledging the admirable things received from you, - upon living and fossil fishes, echinoderms, and glaciers. My admiration of your 
boundless activity, of your beautiful intellectual life, increases with every year. This admiration for your work and your bold excursions is based upon the most careful reading of all the views and investigations, for which I have to thank you. This very week I have read with great satisfaction your truly philosophical address, and your long treatise in Cotta's fourth "Jahresschrift." Even L. von Buch confessed that the first half of your treatise, the living presentation of the succession of organized beings, was full of truth, sagacity, and novelty.

$\mathrm{I}$ in no way reproach you, my dear friend, for the urgent desire expressed in all your letters, that your oldest friends should accept your comprehensive geological view of your ice-period. It is very noble and natural to wish that what has impressed us as true should also be recognized by those we love. ... I believe I have read and compared all that has been written for and against the iceperiod, and also upon the transportation of boulders, whether pushed along or carried by floods or gliding over slopes. My own opinion, as you know, can have no weight or authority, since I have not myself seen the most decisive points. Indeed I am, perhaps 
wrongly, inclined to look upon all geological theories as having their being in a mythical region, in which, with the progress of physics, the phantasms are modified century by century. But the "elephants caught in the ice," and Cuvier's "instantaneous change of climate," seem to me no more intelligible today than when I wrote my Asiatic fragments. According to all that we know of the decrease of heat in the earth, I cannot understand such a change of temperature in a space of time which does not also allow for the decaying of flesh. I understand much better how wolves, hares, and dogs, should they fall to-day into clefts of the frozen regions of Northern Siberia (and the so-called "elephant-ice" is in plain prose only porphyritic drift mixed with ice-crystals, true drift material), might retain their flesh and muscles... But I am only a grumbling rebellious subject in your kingdom. . . . Do not be vexed with a friend who is more than ever impressed with your services to geology, your philosophical views of nature, your profound knowledge of organized beings. . . .

With old attachment and the warmest friendship, your

A. De Humboldt. 
In the same strain is this extract from another letter of Humboldt's, written two or three months later.

. . " GGrace from on high,' says Madame de Sévigné, ' comes slowly.' I especially desire it for the glacial period and for that fatal cap of ice which frightens me, child of the equator that I am. My heresy, of little importance, since I have seen nothing, does not, I assure you, my dear Agassiz, diminish my ardent desire that all your observations should be published. ... I rejoice in the good news you give me of the fishes. I should pain you did I add that this work of yours, by the light it has shed on the organic development of animals, makes the true foundation of your glory." ...

LOUIS AGASSIZ TO SIR PHIIIP EGERTON.

NEUCHÂTEL, JUne, 1842.

... I am hard at work on the fishes of the "Old Red," and will send you at Manchester a part at least of the plates, with a general summary of the species of that formation. I aim to finish the work with such care that it shall mark a sensible advance in ichthyology. I hope it will satisfy you. . . Y You ask me how I intend to finish my Fossil Fishes? As fol- 
lows: As soon as the number on the species of the "Old Red" is finished, I shall complete the general outline of the work as I did with volume 4 , in order that the arrangement and character of all the families in the four orders may be studied in their zoölogical affinities, with their genera and principal species. But as this outline can no longer contain the innumerable species now known to me, I take up monographically the species from the different geological formations in the order of the deposits, and publish as many supplements as there are great formations rich in fossil fishes. I shall limit myself to the species described in the body of the work, merely adding the description of the new species in each deposit, and such additions as I may have to make for those already known. In this way, those who wish to study fossil fishes from the zoölogical stand-point can turn to the work in the original form, while those who wish to study them in their geological relations can confine themselves to the supplements. By means of double registers at the end of each volume, these two distinct parts of the work will be again united as a complete whole. This is the only plan I have been able to devise by which I could publish 
in succession all my materials without burdening my first subscribers, who will thus be free to accept the supplements or not, as they prefer. Should you have occasion to mention this arrangement to the friends of fossil ichthyology, pray do so; it seems to me for the interest of the matter that it should be known. ... I propose to resume with new zeal my researches upon the fossil fishes as soon as I return from an excursion I wish to make in July and August to the glacier of the Aar, where I hope, by a last visit this year, to conclude my labors on this subject. You will be glad to learn that the beautiful barometer you gave me has been my faithful companion in the Alps. . . . I have the pleasure to tell you that the King of Prussia has made me a handsome gift of nearly $£ 200$ for the continuance of my glacial work. I feel, therefore, the greater certainty of completing what remains for me to do....

The campaign of 1842 opened on the 4th of July. The boulder had ceased to be a safe shelter, and was replaced by a rough frame cabin covered with canvas. If the party had some regrets in leaving their picturesque hut beneath the rock, the greater 
comfort of the new abode consoled them. It had several divisions. A sleeping-place for the guides and workmen was partitioned off from a middle room occupied by Agassiz and his friends, while the front space served as dining-room, sitting-room, and laboratory. This outer apartment boasted a table and one or two benches; even a couple of chairs were kept as seats of honor for occasional guests. A shelf against the wall and a few pegs accommodated books, instruments, coats, etc., and a plank floor, on which to spread their blankets at night, was a good exchange for the frozen surface of the glacier. ${ }^{1}$

${ }^{1}$ In bidding farewell to the boulder which had been the first "Hôtel des Neuchâtelois" we may add a word of its farther fortunes. It had begun to split in 1841, and was completely rent asunder in 1844, after which frost and rain completed its dismemberment. Strange to say, during the last summer (1884) certain fragments of the mass have been found, inseribed with the names of some of the party; one of the blocks bearing beside names, the mark No.2. The account says: "The middle stone, the one numbered 2 , was at the intersecting point of two lines drawn from the Pavilion Dollfuss to the Schenchzerhorn on the one part, and from the Rothhorn to the Thierberg on the other." According to the measurements taken by Agassiz, the Hôtel des Neuchâtelois in 1840 stood at 797 metres from the promontory of Abschwung. We are thus enabled, by referring to the large glacier map of Wild and Stengel, to compare the present with the then position of the stone, and thereby ascertain the progress of the glacier since the time in question. Thus the 
Mr. Wild, an engineer of known ability, was now a member of their party, as a topographical survey was to be one of the chief objects of the summer's work. The results of this survey, which was continued during two summers, are embodied in the map accompanying Agassiz's "Système Glaciaire." Experiments upon the extent and connection of the net-work of capillary fissures that admitted water into the interior of the glaciers, occupied Agassiz's own attention during a great part of the summer. In order to ascertain this, colored liquids were introduced into the glacier by means of boring, and it was found that they threaded their way through the mass of the ice and reappeared at lower points with astonishing rapidity. A gallery was cut at a depth of ten metres below the surface, through a wall of ice intervening between two crevasses. The colored liquid poured into a hole above soon appeared on the ceiling of the gallery. The experimenters were surprised to find that at night the same result was obtained, and that the liquid penetrated from the surface to the roof of the gallery even more quickly

boulder still contributes something toward the sequel of the work begun by those who once found shelter beneath it. E. C. A. 
than during the day. This was explained by the fact that the fissures were then free from any moisture arising from surface melting, so that the passage through them was unimpeded. ${ }^{1}$

The comparative rate of advance in the different parts of the glacier was ascertained this summer with greater precision than before. The rows of stakes planted in a straight line across the glacier by Agassiz and Escher de la Linth, in the previous September, now described a crescent with the curve turned toward the terminus of the glacier, showing, - contrary to the expectation of Agassiz, that the centre moved faster than the sides. The

1 Distrust has been thrown upon these results by the failure of more recent attempts to repeat the same experiments. In reference to this, Agassiz himself says: "The infiltration has been denied in consequence of the failure of some experiments in which an attempt was made to introduce colored fluids into the glacier. To this I can only answer that I succeeded completely myself in the self-same experiment which a later investigator found impracticable, and that I see no reason why the failure of the latter attempt should cast a doubt upon the success of the former. The explanation of the difierence in the result may perhaps be found in the fact that as a sponge gorged with water can admit no more fluid than it already contains, so the glacier, under certain circumstances, and especially at noonday in summer, may be so soaked with water that all attempts to pour colored fluids into it would necessarily fail." - See Geological Sketches, by L. Agassiz, p. 236. 



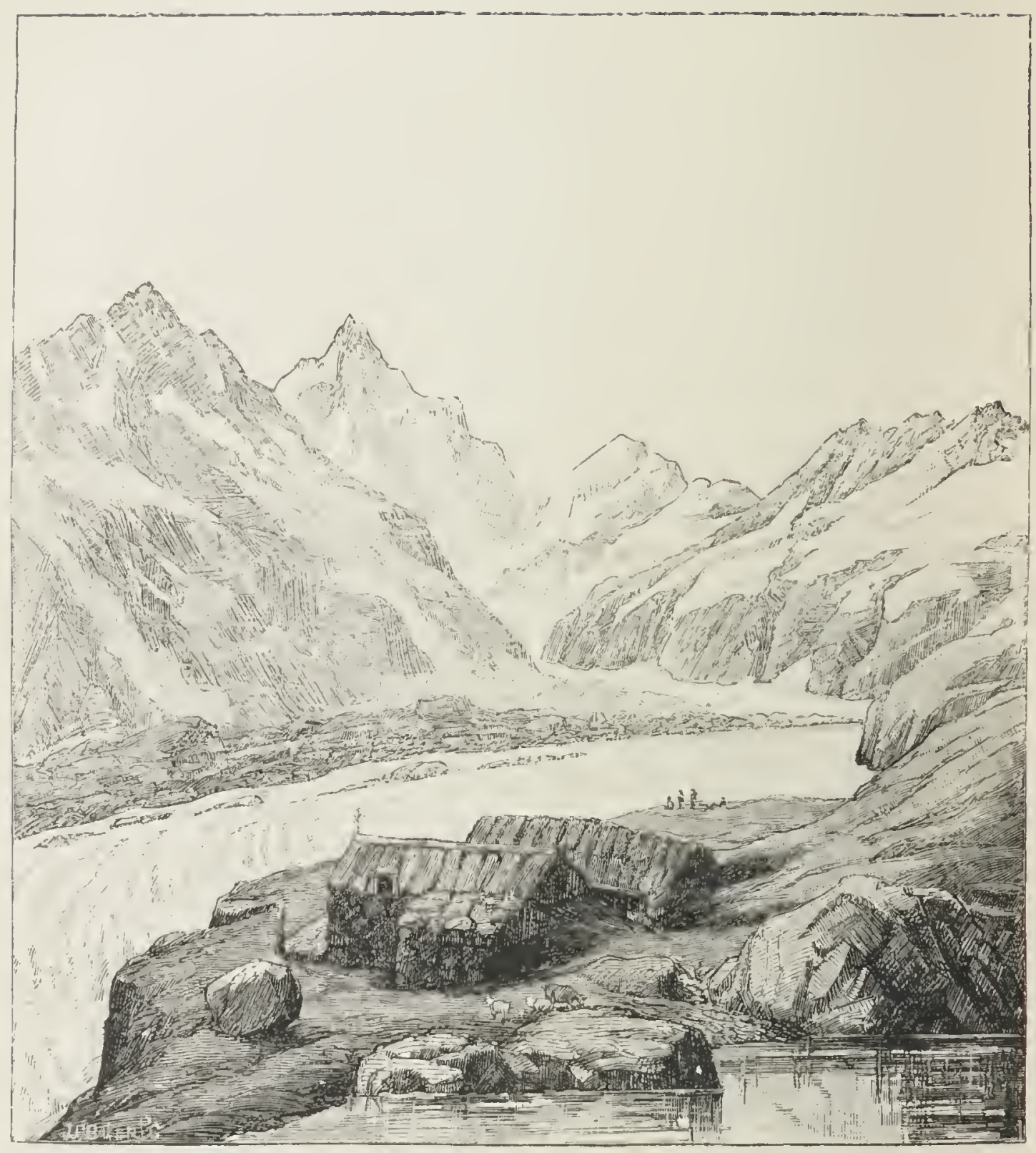

SECOND STATION ON THE AAR GLACIER. 
correspondence of the curve in the stratification with that of the line of stakes confirmed this result. The study of the stratification of the snow was a marked feature of the season's work, and Agassiz believed, as will be seen by a later letter, that he had established this fact of glacial structure beyond a doubt.

The origin and mode of formation of the crevasses also especially occupied the observers. On the 7th of August, Agassiz had an opportunity of watching this phenomenon in its initiation. Attracted to a certain spot on the glacier by a commotion among his workmen, he found them alarmed at the singular noises and movements in the ice. "I heard," he says, "at a little distance a sound like the simultaneous discharge of fire-arms; hurrying in the direction of the noise, it was repeated under my feet with a movement like that of a slight earthquake; the ground seemed to shift and give way under me, but now the sound differed from the preceding, and resembled a crumbling of rocks, without, however, any perceptible sinking of the surface. The glacier actually trembled, nevertheless; for a block of granite three feet in diameter, perched on a pedestal two feet high, suddenly fell down. At the same instant a VOL. I. 
crack opened between my feet and ran rapidly across the glacier in a straight line." 1 On this occasion Agassiz saw three crevasses formed in an hour and a half, and heard others opening at a greater distance from him. He counted eight new fissures in a space of one hundred and twenty-five feet. The phenomenon continued throughout the evening, and recurred, though with less frequency, during the night. The cracks were narrow, the largest an inch and a half in width, and their great depth was proved by the rapidity with which they drained any standing water in their immediate vicinity. "A boring-hole," says Agassiz, "one hundred and thirty feet deep and six inches in diameter, full of water, was completely emptied in a few minutes, showing that these narrow cracks penetrated to great depths."

The summer's work included observations also on the comparative movement of the glacier during the day and night, on the surface waste of the mass, its reparation, on the névé and snow of the upper regions, on the meridian holes, the sun-dials of the glaciers, as they

1 Extract from a letter of Louis Agassiz to M. Arago dated from the Hôtel des Neuchâtelois, Glacier of the Aar, August $7,1842$. 
have been called. ${ }^{1}$ On the whole, the most important result of the campaign was the topographical survey of the glacier, recorded in the map published in Agassiz's second work on the glacier.

At about this time there begin to be occasional references in his correspondence to a journey of exploration in the United States. Especially was this plan in frequent discussion between him and Charles Bonaparte, Prince of Canino, a naturalist almost as ardent as himself, with whom he had long been in intimate scientific correspondence. In April, 1842, the prince writes him: "I indulge myself in dreaming of the journey to America in which you have promised to accompany me.

1 "Here and there on the glacier there are patches of loose material, dust, sand, or gravel, accumulated by diminutive water-rills and small enough to become heated during the day. They will, of course, be warmed first on their eastern side, then still more powerfully on their southern side, and, in the afternoon, with less force again, on their western side, while the northern side will remain comparatively cool. Thus around more than half of their circumference they melt the ice in a semicircle, and the glacier is covered with little crescent-shaped troughs of this description, with a steep wall on one side and a shallow one on the other, and a little heap of loose materials in the bottom. They are the sun-dials of the glacier, recording the hour by the advance of the sun's rays upon them." - Geological Sketches, by L. Agassiz, p. 293. 
What a relaxation! and at the same time what an amount of useful work!" Again, a few months later, "You must keep me well advised of your plans, and I, in my turn, will try so to arrange my affairs as to find myself free in the spring of 1844 for a voyage, the chief object of which will be to show my oldest son the country where he was born, and where man may develop free of shackles. The mere anticipation of this journey is delightful to me, since I shall have you at my side, and may thus feel sure that it will make an epoch in science." This letter is answered from the glacier; the first part refers to the Nomenclator, in regard to which he often consulted the prince.

LOUIS AGASSIZ TO THE PRINCE OF CANINO.

Glacier of the Aar, September 1, 1842.

... I thank you most sincerely for the pains you have so kindly taken with my proof, and for pointing out the faults and omissions you have noticed in my register of birds. I male the corrections at once, and have taken the liberty of mentioning on the cover of this number the share you have consented to take in my Nomenclator. I shall try to do better and better in the successive classes, but you 
well know the impossibility of avoiding grave errors in such a work, and that they can be wholly weeded out only in a second and third edition. I should have written sooner in answer to your last, had not your letter reached me on the Glacier of the Aar, where I have been since the beginning of July, following up observations, the results of which become every day more important and more convincing. The most striking fact, one which I think I have placed beyond the reach of doubt, is the primitive stratification of the névé, or fields of snow, - stratified from the higher regions across the whole course of the glacier to its lower extremity. I have prepared a general map, with transverse sections, showing how the layers lift themselves on the borders of the glacier and also at their junction, where two glaciers meet at the outlet of adjoining valleys; and how, also, the waving lines formed by the layers on the surface change to sharper concentric curves with a marked axis, as the glacier descends to lower levels. For a full demonstration of the matter, I ought to send you my map and plans, of which I have, as yet, no duplicates; but the fact is incontestable, and you will oblige me by announcing it in the geological section at Padua. M. 
Charpentier, who is going to your meeting, will contest it, but you can tell him from me that it is as evident as the stratification of the Neptunic rocks. To see and understand it fully, however, one must stand well above the glacier, so as to command the surface as a whole in one view. I would add that I am not now alluding to the blue and white bands in the ice of which I spoke to you last year; this is a quite distinct phenomenon.

I wish I could accept your kind invitation, but until I have gone to the bottom of the glacier question and terminated my "Fossil Fishes," I do not venture to move. It is no light task to finish all this before our long journey, to which I look forward, as it draws nearer, with a constantly increasing interest. I am very sorry not to join you at Florence. It would have been a great pleasure for me to visit the collections of northern Italy in your company. . . . I write you on a snowy day, which keeps me a prisoner in my tent; it is so cold that I can hardly hold my pen, and the water froze at my bedside last night. The greatest privation is, however, the lack of fruit and vegetables. Hardly a potato once a fortnight, but always and every day, morning and night, mutton, everlasting mutton, 
and rice soup. As early as the end of July we were caught for three days by the snow; I fear I shall be forced to break up our encampment next week without having finished my work. What a contrast between this life and that of the plain! I am afraid my letter may be long on the road before reaching the mail, and I pause here that I may not miss the chance of forwarding it by a man who has just arrived with provisions and is about to return to the hospice of the Grimsel, where some trustworthy guide will undertake to deliver it at the first post-office.

No sooner is Agassiz returned from the glacier than we meet him again in the domain of his fossil fishes.

LOUIS AGASSIZ TO SIR PHILIP EGERTON.

NeuchâteL, December 15, 1842.

... In the last few months I have made an important step in the identification of fossil fishes. The happy idea occurred to me of applying the microscope to the study of fragments of their bones, especially those of the head, and I liave found in their structure modifications as remarkable and as numerous as those which Mr. Owen discovered in the 
structure of teeth. Here there is a vast new field to explore. I have already applied it to the identification of the fossil fishes in the Old Red of Russia sent me for that purpose by Mr. Murchison. You will find more ample details about it in my report to him. I congratulate myself doubly on the results; first, because of their great importance in paleontology, and also because they will draw more closely my relations with Mr. Owen, whom I always rejoice to meet on the same path with myself, and whom I believe incapable of jealousy in such matters. . . The only point indeed, on which I think I may have a little friendly difference with him, is concerning the genus Labyrinthodon, which I am firmly resolved, on proofs that seem to me conclusive, to claim for the class of fishes. ${ }^{1}$ As soon as I have time I will write to $\mathrm{Mr}$. Owen, but this need not prevent you from speaking to him on the subject if you have an early opportunity to do so. I am now exclusively occupied with the fossil fishes, which at any cost I wish to finish this winter... Before even returning to my glacier work, I will finish my monograph of the Old Red, so that you may present it at

1 On seeing Owen's evidence some years later, Agassiz at once acknowledged himself mistaken on this point. 
VARIOUS PUBLICATIONS COMPLETED. 361

the Cork meeting, which it will be impossible for me to attend. . . . I am infinitely grateful to you and Lord Enniskillen for your willingness to trust your Sheppy fishes to me; I shall thus be prepared in advance for a strict determination of these fossils. Having them for some time before my eyes, I shall become familiar with all the details. When I know them thoroughly, and have compared them with the collections of skeletons in the Museums of Paris, of Leyden, of Berlin, and of Halle, I will then come to England to see what there may be in other collections which I cannot have at my disposal here.

The winter of 1843, apart from his duties as professor, was devoted to the completion of the various zoölogical works on which he was engaged, and to the revision of materials he had brought back from the glacier. His habits with reference to physical exercise were very irregular. He passed at once from the life of the mountaineer to that of the closet student. After weeks spent on the snow and ice of the glacier, constantly on foot and in the open air, he would shut himself up for a still longer time in his laboratory, motionless for hours at his microscope by day, and writ- 
ing far into the night, rarely leaving his work till long after midnight. He was also forced at this time to press forward his publications in the hope that he might have some return for the sums he had expended upon them. This was indeed a very anxious period of his life. He could never be brought to believe that purely intellectual aims were not also financially sound, and his lithographic establishment, his glacier work, and his costly researches in zoölogy had proved far beyond his means. The prophecies of his old friend Humboldt were coming true. He was entangled in obligations, and crushed under the weight of his own undertakings. He began to doubt the possibility of carrying out his plan of a scientific journey to the United States.

AGASSIZ TO THE PRINCE OF CANINO.

Neuchâtel, April, 1843.

.. I have worked like a slave all winter to finish my fossil fishes; you will presently receive my fifteenth and sixteenth numbers, forwarded two days since, with more than forty pages of text, containing many new observations. I shall allow myself no interruption until this work is finished, hoping there- 
by to obtain a little freedom, for if my position here is not changed I shall be forced to seek the means of existence elsewhere. Meantime, extravagant projects present themselves, as is apt to be the case when one is in difficulties. That of accompanying you to the United States was so tempting, that I am bitterly disappointed to think that its execution becomes impossible in my present circumstances. All my projects for further publications must also be adjourned, or perhaps renounced. ... Possibly, when my work on the fossil fishes is completed, the sale of some additional copies may help me to rise again. And yet I have not much hope of this, since all the attempts of my friends to obtain subscriptions for me in France and Russia have failed: because the French government takes no interest in what is done out of Paris; and in Russia such researches, having little direct utility, are looked upon with indifference. Do you think any position would be open to me in the United States, where I might earn enough to enable me to continue the publication of my unhappy books, which never pay their way because they do not meet the wants of the world? ... 
In the following July we find him again upon the glacier. But the campaign of 1843 opened sadly for the glacial party. Arriving at Meiringen they heard that Jacob Leuthold was ill and would probably be unable to accompany them. They went to his house, and found him, indeed, the ghost of his former self, apparently in a rapid decline. Nevertheless, he welcomed them gladly to his humble home, and would have kept them for some refreshment. Fearing to fatigue him, however, they stayed but a few moments. As they left, one of the party pointed to the mountains, adding a hope that he might soon join them. His eyes filled with tears; it was his only answer, and he died three days later. $\mathrm{He}$ was but thirty-seven years of age, and at that time the most intrepid and the most intelligent of the Oberland guides. His death was felt as a personal grief by the band of workers whose steps he had for years guided over the most difficult Alpine passes.

The summer's work continued and completed that of the last season. On leaving the glacier the year before they had marked a net-work of loose boulders, such as travel with the ice, and also a number of fixed points in the valley walls, comparing and registering 
their distance from each other. They had also sunk a line of stakes across the glacier. - The change in the relative position of the two sets of signals and the curve in their line of stakes gave them, self-recorded, as it were, the rate of advance of the glacier as a whole, and also the comparative rate of progression in its different parts. Great pains was also taken during the summer to measure the advance in every twenty-four hours, as well as to compare the diurnal with the nocturnal movement, and to ascertain the amount of surface waste. The season was an unfavorable one, beginning so late and continuing so cold that the period of work was shortened. 


\section{CHAPTER XII.}

$$
1843-1846 \text { : ÆET. } 36-39 \text {. }
$$

Completion of Fossil Fishes. - Followed by Fossil Fishes of the Old Red Sandstone. - Review of the Later Work. Identification of Fishes by the Skull. - Renewed Correspondence with Prince Canino about Journey to the United States. - Cliange of Plan owing to the Interest of the King of Prussia in the Expedition. - Correspondence between Professor Sedgwick aud Agassiz on Development Theory. - Final Scientific Work in Neuchâtel and Paris. -Publication of "Système Glaciaire." - Short Stay in England. - Sails for United States.

Is 1843 the "Recherches sur les Poissons Fossiles" was completed, and fast upon its footsteps, in 1844, followed the author's "Monograph on the Fossil Fishes of the Old Red Sandstone, or the Devonian System of Great Britain and Russia," a large quarto volume of text, accompanied by forty-one plates. Nothing in his paleontological studies ever interested Agassiz more than this curious fauna of the Old Red, so strange in its combinations that even well-informed naturalists had attributed its fossil remains to various classes of the animal kingdom in turn, and, indeed, long 
remained in doubt as to their true nature. Agassiz says himself in his Preface: "I can never forget the impression produced upon me by the sight of these creatures, furnished with appendages resembling wings, yet belonging, as I had satisfied myself, to the class of fishes. Here was a type entirely new to us, about to reënter (for the first time since it had ceased to exist) the series of beings; nor could anything, thus far revealed from extinct creations, have led us to anticipate its existence. So true is it that observation alone is a safe guide to the laws of development of organized beings, and that we must be on our guard against all those systems of transformation of species so lightly invented by the imagination."

The author goes on to state that the discovery of these fossils was mainly due to Hugh Miller, and that his own work had been confined to the identification of their character and the determination of their relations to the already known fossil fishes. This work, upon a type so extraordinary, implied, however, innumerable and reiterated comparisons, and a minute study of the least fragments of the remains which could be procured. The materials were chiefly obtained in Scotland; but Sir Roderick Murchison also contributed his own 
collection from the Old Red of Russia, and various other specimens from the same locality. Not only on account of their peculiar structure were the fishes of the Old Red interesting to Agassiz, but also because, with this famna, the vertebrate type took its place for the first time in what were then supposed to be the most ancient fossiliferous beds. When Agassiz first began his researches on fossil fishes, no vertebrate form had been discovered below the coal. The occurrence of fishes in the Devonian and Silurian beds threw the vertebrate type back, as he believed, into line with all the invertebrate classes, and seemed to him to show that the four great types of the animal kingdom, Radiates, Mollusks, Articulates, and Vertebrates, had ap"peared together." "It is henceforth demonstrated," says Agassiz, "that the fishes were included in the plan of the first organic combinations which made the point of departure for all the living inhabitants of our globe in the series of time."

In his opinion this simultaneity of appearance, as well as the richness and variety displayed by invertebrate classes from the begin-

1 Introduction to the Poissons Fossiles du Vieux Grès Rouge, p. 22. 
ning, made it " "impossible to refer the first inhabitants of the earth to a few stocks, subsequently differentiated under the influence of external conditions of existence." . . . He adds : "I have elsewhere presented my views upon the development through which the successive creations have passed during the history of our planet. But what I wish to prove here, by a careful discussion of the facts reported in the following pages, is the truth of the law now so clearly demonstrated in the series of vertebrates, that the successive creations have undergone phases of development analogous to those of the embryo in its growth and similar to the gradations shown by the present creation in the ascending series, which it presents as a whole. One may consider it as henceforth proved that the embryo of the fish during its development, the class of fishes as it at present exists in its numerous families, and the type of fish in its planetary history, exhibit analogous phases through which one may follow the same creative thought like a guiding thread in the study of the connection

${ }^{1}$ Introduction to the Poissons Fossiles du I'ieux Grès Rouge, p. 21.

2 Introduction to the Poissons Fossiles du Vieux Grès Rouge, p. 24 .

vor 1 . 
between organized beings." Following this comparison closely, he shows how the early embryonic condition of the present fishes is recalled by the general disposition of the fins in the fishes of the Old Red Sandstone, and especially by the caudal fin, making the unevenly lobed tail, so characteristic of these ancient forms. This so called heterocercal tail is only known to exist, as a permanent adult feature, in the sturgeons of to-day. The form of the head and the position of the mouth and eyes in the fishes of the Old Red were also shown to be analogous with embryonic phases of our present fishes. From these analogies, and also from the ascendency of fishes as the only known vertebrate, and therefore as the highest type in those ancient deposits, Agassiz considered this fauna as representing "the embryonic age of the reign of fishes;" and he sums up his results in conclusion in the following words: "The facts, taken as a whole, seem to me to show, not only that the fishes of the Old Red constitute an independent fauna, distinct from those of other deposits, but that they also represent in their organization the most remarkable analogy with the first phases of embryonic development in the bony fishes of our epoch, and a no less 
marked parallelism with the lower degrees of certain types of the class as it now exists on the surface of the earth."

It has been said by one of the biographers of Agassiz, ${ }^{1}$ in reference to this work upon the fishes of the Old Red Sandstone: "It is difficult to understand why the results of these admirable researches, and of later ones made by him, did not in themselves lead him to support the theory of transformation, of which they seem the natural consequence." It is true that except for the frequent allusion to a creative thought or plan, this introduction to the Fishes of the Old Red might seem to be written by an advocate of the development theory rather than by its most determined opponent, so much does it deal with laws of the organic world, now used in support of evolution. These comprehensive laws, announced by Agassiz in his "Poissons Fossiles," and afterward constantly reiterated by him, have indeed been adopted by the writers on evolution, though with a wholly different interpretation. No one saw more clearly than Agassiz the relation which he first pointed out, between the succession of animals of the same type in time and the phases of their em1 Louis Agassiz: Notice biographique, par Ernest Favre. 
bryonic growth to-day, and he often said, in his lectures, "the history of the individual is the history of the type." But the coincidence between the geological succession, the embryonic development, the zoölogical gradation, and the geographical distribution of animals in the past and the present, rested, according to his belief, upon an intellectual coherence and not upon a material connection. So, also, the variability, as well as the constancy, of organized beings, at once so plastic and so inflexible, seemed to him controlled by something more than the mechanism of self-adjusting forces. In this conviction he remained unshaken all his life, although the development theory came up for discussion under so many various aspects during that time. His views are now in the descending scale; but to give them less than their real prominence here would be to deprive his scientific career of its true basis. Belief in a Creator was the keynote of his study of nature.

In summing up the comprehensive results of Agassiz's paleontological researches, and especially of his "Fossil Fishes," Arnold Guyot says: ${ }^{1}$

"Whatever be the opinions which many

${ }^{1}$ See Biographical Memoir of Louis Agassiz, p. 28. 
may entertain as to the interpretation of some of these generalizations, the vast importance of these results of Agassiźs studies may be appreciated by the incontestable fact, that nearly all the questions which modern paleontology has treated are here raised and in great measure solved. They already form a code of general laws which has become a foundation for the geological history of the life-system, and which the subsequent investigations of science have only modified and extended, not destroyed. Nowhere did the mind of Agassiz show more power of generalization, more vigor, or more originality. The discovery of these great truths is truly his work; he derived them immediately from nature by his own observations. Hence it is that all his later zoölogical investigations tend to a common aim, namely, to give by farther studies, equally conscientious but more extensive, a broader and more solid basis to those laws which he had read in nature and which he had proclaimed at that early date in his immortal work, ' Poissons Fossiles.' Let us not be astonished that he should have remained faithful to these views to the end of his life. It is because he had seen that he believed, and such a faith is not easily shaken by new hypotheses." 
LOUIS AGASSIZ TO SIR PHILIP EGERTON.

Neuchâted, September 7, 1844.

- . I write in all haste to ask for any address to which I can safely forward my report on the Sheppy fishes, so that they may arrive without fail in time for the meeting at York. Since my last letter I have made progress in this kind of research. I have sacrificed all my duplicates of our present fishes to furnish skeletons. I have prepared more than a hundred since I last wrote you, and I can now determine the family, and even the genus, simply by seeing the skull. There remains nothing impossible now in the determination of fishes, and if I can obtain certain exotic genera, which I have not as yet, I can make an osteology of fishes as complete as that which we possess for the other classes of vertebrates. Every family has its special type of skull. All this is extremely interesting. I have already corrected a mass of inaccurate identifications established upon external characters; and as for fossils, I have recognized and characterized seventeen new genera among the less perfect undetermined specimens you have sent me. Several families appear now for the first time among the fossils. I have been able to 
determine to what family all the doubtful genera belong; indeed Sheppy will prove as rich in species as Mont Bolca. When you see your specimens again you will hardly recognize them, they are so changed; I have chiseled and cleaned them, until they are almost like anatomical preparations. Try to procure as many more specimens as possible and send them to me. I cannot stir from Neuchâtel, now that I am so fully in the spirit of work, and besides it would be a useless expense.... You will receive with my report the three numbers which complete my monograph of the Fishes of the Old Red. I feel sure, in advance, that you will be satisfied with them. . . .

SIR PHIIIP EGERTON TO LOUIS AGASSIZ.

$\left.\begin{array}{c}\text { Tolly House, Alness, Ross-shire. } \\ \text { September } 15,1844 .\end{array}\right\}$

- . I have only this day received your letter of the 6th, and I fear much you will scarcely receive this in time to make it available. I shall not be able to reach York for the commencement of the meeting, but hope to be there on Saturday, September 28th. A parcel will reach me in the shortest possible time addressed Sir P. Egerton, Donnington 
Rectory, York. I am delighted with the bright results of your comparison of the Sheppy fossils with recent forms. You appear to have opened out an entirely new field of investigation, likely to be productive of most brilliant results. Should any accident delay the arrival of your monograph for the York meeting, I shall malke a point of communicating to our scientific friends the contents of your letter, as I know they will rejoice to hear of the progress of fossil ichthyology in your masterly hands. When next you come, I wish you could spend a few days here. We are surrounded on all sides by the débris of the moraines of the ancient glaciers that descended the flank of Ben Wyvis, and I think you would find much to interest you in tracing their relations. We have also the Cromarty Fish-beds within a few miles, and many other objects of geological interest. . . . I shall see Lord Enniskillen at York, and will tell him of your success. We shall, of course, procure all the Sheppy fish we can either by purchase or exchange. . .

The pressure of work upon his various publications detained Agassiz at home during the summer of 1844. For the first time he was 
unable to make one of the glacial party this year, but the work was carried on uninterruptedly, and the results reported to him. Meantime his contemplated journey to the United States flitted constantly before him.

AGASSIZ TO THE PRINCE OF CANINO.

Neuchâtel, November 19, 1844 . ... Your idea of an illustrated American ichthyology is admirable. But for that we ought to have with us an artist clever enough to paint fishes rapidly from the life. Work but half done is no longer permissible in our days. ... In this matter I think there is a justice due to Rafinesque. However poor his descriptions, he nevertheless first recognized the necessity of multiplying genera in ichthyology, and that at a time when the thing was far more difficult than now. Several of his genera have even the priority over those now accepted, and I think in the United States it would be easier than elsewhere to find again a part of the materials on which he worked. We must not neglect from this time forth to ask Americans to put us in the way of extending this work throughout North America. If you accept me for your collaborator, I will at once do all that I can on my 
side to bring together notes and specimens. I will write to several naturalists in the United States, and tell them that as I am to accompany you on your voyage I should be glad to know in advance what they have done in ichthyology, so that we may be the better prepared to profit by our short sojourn in their country. However, I will do nothing before having your directions, which, for the sake of the matter in hand, I should be glad to receive as early as possible. . . .

The next letter announces a new aspect of the projected journey. In explanation, it should be said that finding Agassiz might be prevented by his poverty from going, the prince had invited him to be his guest for a summer in the United States.

AGASSIZ TO THE PRINCE OF CANINO.

NeUChÂtex, January 7, 1845.

.. I have received an excellent piece of news from Humboldt, which I hasten to share with you. I venture to believe that it will please you also.... I had written to Humboldt of our plans, and of your kind offer to take me with you to the United States, telling him at the same time how much I regret- 
ted that I should be unable to visit the regions which attracted me the most from a geological point of view, and asking him if it would be possible to interest the king in this journey and obtain means from his majesty for a longer stay on the other side of the Atlantic. I have just received a delightful and most unexpected reply. The king will grant me 15,000 francs for this object, so that I shall, in any event, be able to make the journey. All the more do I desire to make it in your society, and I think by combining our forces we shall obtain more important results; but I am glad that I can do it without being a burden to you. Before answering Humboldt, I am anxious to know whether your plans are definitely decided upon for this summer, and whether this arrangement suits you. ...

The pleasant plan so long meditated was not to be fulfilled. The prince was obliged to defer the journey and never accomplished it. This was a great disappointment to Agassiz.

"Am I then to go without you," he writes; " is this irrevocable? If I were to defer my departure till September would it then be possible for you to leave Rome? It would be 
too delightful if we could make this journey together. I wish also, before starting, to review everything that has been done of late in paleontology, zoölogy, and comparative anatomy, that I may, in behalf of all these sciences, take advantage of the circumstances in which I shall be placed. . . . Whatever befalls me, I feel that I shall never cease to consecrate my whole energy to the study of nature; its all powerful charm has taken such possession of me that I shall always sacrifice everything to ic; even the things which men usually value most."

Agassiz had determined, before starting on his journey, to complete all his unfinished works, and to put in order his correspondence and collections, including the vast amount of specimens sent him for identification or for his own researches. The task of "setting his house in order" for a change which, perhaps, he dimly felt to be more momentous than it seemed, proved long and laborious. From all accounts, he performed prodigies of work, but the winter and spring passed, and the summer of 1845 found him still at his post.

Humboldt writes him not without anxiety lest his determination to complete all the tasks he had undertaken, including the Nomenclator, 
should involve him in endless delays and perplexities.

\author{
HUMBOLDT TO AGASSIZ.
}

Berlin, September 16, 1845.

. . Your Nomenclator frightens me with its double entries. The Millky Way must have crossed your path, for you seem to be dealing with nebulæ which you are trying to resolve into stars. For pity's sake husband your strength. You treat this journey as if it were for life. As to finishing, - alas! my friend, one does not finish. Considering all that you have in your well-furnished brain beside your accumulated papers, half the contents of which you do not yourself know, your expression "aŭfräumen," - to put in final order, is singularly inappropriate. There will always remain some burdensome residue, - last things not yet accounted for. I beg you, then, not to abuse your strength. Be content to finish only what seems to you nearest completion, - the most advanced of your work.

Your letter reached me, unaccompanied, however, by the books it announces. They are to come, no doubt, in some other way. Spite of the demands made upon me by the continuation of my "Cosmos," I shall find 
time to read and profit by your introduction to the Old Red. I am inclined to sing hymns of praise to the Hyperboreans who have helped you in this admirable work. What you say of the specific difference in vertical line and of the increased number of biological epochs is full of interest and wisdom. No wonder you rebel against the idea that the Baltic contains microscopic animals identical with those of the chalk! I foresee, however, a new battle of Waterloo between you and my friend Ehrenberg, who accompanied me lately, just after the Victoria festivals, to the volcanoes of the Eifel with Dechen. Not an inch of ground without infusoria in those regions! For Heaven's sake do not meddle with the infusoria before you have seen the Canada Lakes and completed your journey. Defer them till some more tranquil period of your life. . . . I must close my letter with the hope that you will never doubt my warm affection. Assuredly I shall find no fault with any course of lectures you may give in the new world, nor do I see the least objection to giving them for money. You can thus propagate your favorite views and spread useful knowledge, while at the same time you will, by most honorable and praiseworthy means, provide additional funds for your traveling expenses. . . . 
The following correspondence with Professor Adam Sedgwick is of interest, as showing his attitude and that of Agassiz toward questions which have since acquired a still greater scientific importance.

PROFESSOR ADAM SEDGWICK TO LOUIS AGASSIZ.

$$
\left.\begin{array}{c}
\text { Trinity Coll., Cambridge, } \\
\text { April 10, } 1845 .
\end{array}\right\}
$$

My dear Professor, - The British Association is to meet here about the middle of June, and I trust that the occasion will again bring you to England and give me the great happiness of entertaining you in Trinity College. Indeed, I wish very much to see you; for many years have now elapsed since I last had that pleasure. May God long preserve your life, which has been spent in promoting the great ends of truth and knowledge! Your great work on fossil fishes is now before me, and I also possess the first number of your monograph upon the fishes of the Old Red Sandstone. I trust the new numbers will follow the first in rapid succession. I love now and then to find a resting-place; and your works always give me one. The opinions of Geoffroy St. Hilaire and his dark school seem to be gaining some ground in England. I 
detest them, because I think them untrue. They shut out all argument from design and all notion of a Creative Providence, and in so doing they appear to me to deprive physiology of its life and strength, and language of its beauty and meaning. I am as much offended in taste by the turgid mystical bombast of Geoffroy as I am disgusted by his cold and irrational materialism. When men of his school talk of the elective affinity of organic types, I hear a jargon I cannot comprehend, and I turn from it in disgust; and when they talk of spontaneous generation and transmutation of species, they seem to me to try nature by an hypothesis, and not to try their hypothesis by nature. Where are their facts on which to form an inductive truth? I deny their starting condition. "Oh! but" they reply, "we have progressive development in geology." Now, I allow (as all geologists must do) a kind of progressive development. For - example, the first fish are below the reptiles; and the first reptiles older than man. I say, we have successive forms of animal life adapted to successive conditions (so far, proving design), and not derived in natural succession in the ordinary way of generation. But if no single fact in actual nature allows 
us to suppose that the new species and orders were produced successively in the natural way, how did they begin? I reply, by a way out of and above common known, material nature, and this way I call creation. Generation and creation are two distinct ideas, and must be described by two distinct words, unless we wish to introduce utter confusion of thought and language. In this view I think you agree with me; for I spoke to you on the subject when we met (alas, ten years since!) at Dublin. Would you have the great kindness to give me your most valuable opinion on one or two points?

(1.) Is it possible, according to the known laws of actual nature, or is it probable, on any analogies of nature, that the vast series of fish, from those of the Ludlow rock and the Old Red Sandstone to those of our actual seas, lakes, and rivers, are derived from one common original low type, in the way of development and by propagation or natural breeding? I should say, no. But my knowledge is feeble and at second-hand. Yours is strong and from the fountain-head.

(2.) Is the organic type of fish higher now than it was during the carboniferous period, when the Sauroids so much abounded? If voL. I. 
the progressive theory of Geoffroy be true, in his sense, each class of animals ought to be progressive in its organic type. It appears to me that this is not true. Pray tell me your own views on this point.

(3.) There are "odd fish" (as we say in jest) in the Old Red Sandstone. Do these so graduate into crustaceans as to form anything like such an organic link that one could, by generation, come naturally from the other? I should say, no, being instructed by your labors. Again, allowing this, for the sake of argument, are there not much higher types of fish which are contemporaneous with the lower types (if, indeed, they be lower), and do not these nobler fish of the Old Red Sandstone stultify the hypothesis of natural generative development?

(4.) Will you give me, in a few general words, your views of the scale occupied by the fish of the Old Red, considered as a natural group? Are they so rudimentary as to look like abortions or creatures derived from some inferior class, which have not yet by development reached the higher type of fish? Again, I should say, no; but I long for an answer from a great authority like yours. I am most anxious for a good general concep- 
LETTER TO PROFESSOR SEDGWICK. 387 tion of the fish of the Old Red, with reference to some intelligible scale.

(5.) Lastly, is there the shadow of ground for supposing that by any natural generative development the Ichthyosaurians and other kindred forms of reptile have come from Sauroid, or any other type of fish? I believe you* will say, no. At any rate, the facts of geology lend no support to such a view, for the nobler forms of Reptile appear in strata below those in which the Ichthyosaurians, etc., are first seen. But I must not trouble you with more questions. Professor Whewell is now Master of Trinity College. We shall all rejoice to see you.

Ever, my dear Professor, your most faithful and most grateful friend,

\section{A. Sedgwick.}

FROM LOUIS AGASSIZ TO A. SEDGWICK.

NeuChâtel, June, 1845.

... I reproach myself for not acknowledging at once your most interesting letter of April 10th. But you will easily understand that in the midst of the rush of work consequent upon my preparation for a journey of several years' duration I have not noticed the flight of time since I received it, until to-day, 
when the sight of the date fills me with confusion. And yet, for years, I have not received a letter which has given me greater pleasure or moved me more deeply. I have felt in it and have received from it that vigor of conviction which gives to all you say or write a virile energy, captivating alike to the listener or the reader. Like you, I am pained by the progress of certain tendencies in the domain of the natural sciences; it is not only the arid character of this philosophy of nature (and by this I mean, not natural philosophy, but the "Natur-philosophie" of the Germans and French) which alarms me. I dread quite as much the exaggeration of religious fanaticism, borrowing fragments from science, imperfectly or not at all understood, and then making use of them to prescribe to scientific men what they are allowed to see or to find in Nature. Between these two extremes it is difficult to follow a safe road. The reason is, perhaps, that the domain of facts has not yet received a sufficiently general recognition, while traditional beliefs still have too much influence upon the study of the sciences.

Wishing to review such ideas as I had formed upon these questions, I gave a public course this winter upon the plan of creation 
as shown in the development of the animal kingdom. I wish I could send it to you, for I think it might please you. Unhappily, I had no time to write it out, and have not even an outline of it. But I intend to work further upon this subject and make a book upon it one of these days. If I speak of it to-day it is because in this course I have treated all the questions upon which you ask my opinion. Let me answer them here after a somewhat aphoristic fashion.

I find it impossible to attribute the biological phenomena, which have been and still are going on upon the surface of our globe, to the simple action of physical forces. I believe they are due, in their entirety, as well as individually, to the direct intervention of a creative power, acting freely and in an autonomic way. ... I have tried to make this intentional plan in the organization of the animal kingdom evident, by showing that the differences between animals do not constitute a material chain, analogous to a series of physical phenomena, bound together by the same law, but present themselves rather as the phases of a thought, formulated according to a definite aim. I think we know enough of comparative anatomy to abandon forever the idea of 
the transformation of the organs of one type into those of another. The metamorphoses of certain animals, and especially of insects, so often cited in support of this idea, prove, by the fixity with which they repeat themselves in innumerable species, exactly the contrary. In the persistency of these metamorphoses, distinct for each species and known to repeat themselves annually in a hundred thousand species, and to have done so ever since the present order of things was established on the earth, have we not the most direct proof that the diversity of types is not due to external natural influences? I have followed this idea in all the types of the animal kingdom. I have also tried to show the direct intervention of a creative power in the geographical distribution of organized beings on the surface of the globe when the species are definitely circumscribed. As evidence of the fixity of generic types and the existence of a higher and free causal power, I have made use of a method which appears to me new as a process of reasoning. The series of reptiles, for instance, in the family of lizards, shows apodal forms, forms with rudimentary feet, then with a successively larger number of fingers until we reach, by seemingly insensible gradations, 
the genera Anguis, Ophisaurus, and Pseudopus, the Chamosauria, Chirotes, Bipes, Sepo, Scincus, and at last the true lizards. It would seem to any reasonable man that these types are the transformations of a single primitive type, so closely do the modifications approach each other; and yet I now reject any such supposition, and after having studied the facts most thoroughly, I find in them a direct proof of the creation of all these species. It must not be forgotten that the genus Anguis belongs to Europe, the Ophisaurus to North America, the Pseudopus to Dalmatia and the Caspian steppe, the Sepo to Italy, etc. Now, I ask how portions of the earth so absolutely distinct could have combined to form a continuous zoölogical series, now so strikingly distributed, and whether the idea of this development could have started from any other source than a creative purpose manifested in space? These same purposes, this same constancy in the employment of means toward a final end, may be read still more clearly in the study of the fossils of the different creations. The species of all the creations are materially and genealogically as distinct from each other as those of the different points on the surface of the globe. I have compared hundreds of spe- 
cies reputed identical in various successive deposits, - species which are always quoted in favor of a transition, however indirect, from one group of species to another, - and I have always found marked specific differences between them. In a few weeks I will send you a paper which $I$ have just printed on this subject, where it seems to me this view is very satisfactorily proved. The idea of a procreation of new species by preceding ones is a gratuitous supposition opposed to all sound phys- iological notions. "And yet it is true that, taken as a whole, there is a gradation in the organized beings of successive geological formations, and that the end and aim of this development is the appearance of man. But this serial connection of all successive creatures is not material; taken singly these groups of species show no relation through intermediate forms genetically derived one from the other. The connection between them becomes evident only when they are considered as a whole emanating from a creative power, the author of them all. To your special questions I may now very briefly reply.

Have fishes descended from a primitive type? So far am I from thinking this possible, that I do not believe there is a single 
specimen of fossil or living fish, whether marine or fresh-water, that has not been created with reference to a special intention and a definite aim, even though we may be able to detect but a portion of these numerous relations and of the essential purpose.

- Are the present fishes superior to the older ones? As a general proposition, I would say, no; it seems to me even that the fishes which preceded the appearance of reptiles in the plan of creation were higher in certain characters than those which succeeded them; and it is a strange fact that these ancient fishes have something analogous with reptiles, which had not then made their appearance. One would say that they already existed in the creative thought, and that their coming, not far removed, was actually anticipated.

Can the fishes of the Old Red be considered the embryos of those of later epochs? Of course they are the first types of the vertebrate series, including the most ancient of the Silurian system; but they each constitute an independent fauna, as numerous in the places where these earlier fishes are found, as the present fishes in any area of similar extent on our sea-shore to-day. I now know one hundred and four species of fossil fish from 
the Old Red, belonging to forty-four genera, comprised under seven families, between several of which there is but little analogy as to organization. It is therefore impossible to look upon them as coming from one primitive stock. The primitive diversity of these types is quite as remarkable as that of those belonging to later epochs. It is nevertheless true that, regarded as part of the general plan of creation, this fauna presents itself as an inferior type of the vertebrate series, connecting itself directly in the creative thought with the realization of later forms, the last of which (and this seems to me to have been the general end of creation) was to place man at the head of organized beings as the key-stone and term of the whole series, the final point in the premeditated intention of the primitive plan which has been carried out progressively in the course of time. I would even say that I believe the creation of man has closed creation on this earth, and I draw this conclusion from the fact that the human genus is the first cosmopolite type in Nature. One may even affirm that man is clearly announced in the phases of organic development of the animal kingdom as the final term of this series.

Lastly: Is there any reason to believe that 
the Ichthyosaurians are descendants of the Sauroid fishes which preceded the appearance of these reptiles? Not the least. I should consider any naturalist who would seriously present the question in this light as incapable of discussing it or judging it. He would place himself outside of the facts and would reason from a basis of his own creating. ...

In the "Revue Suisse" of April, 1845, there is a notice of the course of lectures to which reference is made in the above letter.

"A numerous audience assembled on the 26th of March for the opening of a course by Professor Agassiz on the 'Plan of Creation.' It is with an ever new pleasure that our public come together to listen to this savant, still so young and already so celebrated. Not content with pursuing in seclusion his laborious scientific investigations, he makes a habit of communicating, almost annually, to an audience less restricted than that of the Academy the general result of some of his researches. All the qualities to which Mr. Agassiz has accustomed his listeners were found in the opening prelude; the fullness and freedom of expression which give to his lectures the character of a scientific causerie; the dignified 
ease of bearing, joined with the simplicity and candor of a savant who teaches neither by aphorisms nor oracles, but who frankly admits the public to the results of his researches; the power of generalization always based upon a patient study of facts, which he knows how to present with remarkable clearness in a language that all can understand. We will not follow the professor in tracing the outlines of his course. Suffice it to say that he intends to show in the general development of the animal kingdom the existence of a definite preconceived plan, successively carried out; in other words, the manifestation of a higher thought, - the thought of God. This creative thought may be studied under three points of view: as shown in the relations which, spite of their manifold diversity, connect all the species now living on the surface of the globe; in their geographical distribution; and in the succession of beings from primitive epochs until the present condition of things."

The summer of 1845 was the last which Agassiz passed at home. It was broken by a short and hurried visit to the glacier of the Aar, respecting which no details have been preserved. He did not then know that 
he was taking a final leave of his cabin among the rocks and ice. Affairs connected with the welfare of the institution in Neuchâtel, with which he had been so long connected, still detained him for a part of the winter, and he did not leave for Paris until the first week in March, 1846. His wife and daughters had already preceded him to Germany, where he was to join them again on his way to Paris, and where they were to pass the period of his absence, under the care of his brother-in-law, Mr. Alexander Braun, then living at Carlsruhe. His son was to remain at school at Neuchâtel.

It was two o'clock at night when he left his home of so many years. There had been a general sadness at the thought of his departure, and every testimony of affection and respect accompanied him. The students came in procession with torchlights to give him a parting serenade, and many of his friends and colleagues were also present to bid him farewell. M. Louis Favre says in his Memoir, "Great was the emotion at Neuchâtel when the report was spread abroad that Agassiz was about to leave for a long journey. It is true he promised to come back, but the New World might shower upon him such marvels 
that his return could hardly be counted upon. The young people, the students, regretted their beloved professor not only for his scientific attainments, but for his kindly disposition, the charm of his eloquence, the inspiration of his teaching; they regretted also the gay, animated, untiring companion of their excursions, who made them acquainted with nature, and knew so well how to encourage and interest them in their studies."

Pausing at Carlsruhe on his journey, he proceeded thence to Paris, where he was welcomed with the greatest cordiality by scientific men. In recognition of his work on the "Fossil Fishes" the Monthyon Prize of Physiology was awarded him by the Academy. He felt this distinction the more because the bearing of such investigations upon experimental physiology had never before been pointed out, and it showed that he had succeeded in giving a new direction and a more comprehensive character to paleontological research. He passed some months in Paris, busily occupied with the publication of the "Système Glaciaire," his second work on the glacial phenomena. The "Etudes sur les Glaciers" had simply contained a résumé of all the researches undertaken upon the Al- 
pine fields of ice and the results obtained up to 1840 , inclusive of the author's own work and his wider interpretation of the facts. The "Système Glaciaire" was, on the contrary, an account of a connected plan of investigation during a succession of years, upon a single glacier, with its geodetic and topographic features, its hydrography, its internal structure, its atmospheric conditions, its rate of annual and diurnal progress, and its relations to surrounding glaciers. All the local phenomena, so far as they could be observed, were subjected to a strict scrutiny, and the results corrected by careful comparison, during five seasons. As we have seen, and as Agassiz himself says in his Preface, this band of workers had "lived in the intimacy of the glacier, striving to draw from it the secret of its formation and its annual advance." The work was accompanied by three maps and nine plates. In such a volume of detail there is no room for picturesque description, and little is told of the wonderful scenes they witnessed by day and night, nothing of personal peril and adventure.

This task concluded, he went to England, where he was to spend the few remaining days previous to his departure. Among the 
last words of farewell which reached him just as he was leaving the Old World, little thinking then that he was to make a permanent home in America, were these lines from Humboldt, written at Sans Souci: "Be happy in this new undertaking, and preserve for me the first place under the head of friendship in your heart. When you return I shall be here no more, but the king and queen will receive you on this 'historic hill' with the affection which, for so many reasons, you merit. ...

"Your illegible but much attached friend, "A. Humboldt."

So closed this period of Agassiz's life. The next was to open in new scenes, under wholly different conditions. He sailed for America in September, 1846. 




\title{
BOOKS BY LOUIS AGASSIZ,
}

Published by

\section{HOUGHTON, MIFFLIN AND COMPANY,}

4 Park Street, Boston;

II EAST I7TH Street, New YORK.

\section{METHODS OF STUDY IN NATURAL HISTORY.}

\author{
By Louis Agassiz. With Illustrations. \\ r6mo, \$1.50.
}

CONTENTS :

I. General Sketch of the Early Progress in Natural History

II. Nomenclature and Classification.

III. Categories of Classification.

IV. Classification and Creation.

V. Different Views respecting Orders.

VI. Gradation among Animals.

VII. Analogous Types.

VIII. Family Characteristics.

IX. The Cnaracter of Genera.

$\mathrm{X}$. Species and Breeds.

XI. Formation of Coral Reefs.

XII. Age of Coral Reefs as showing Permanence of Species.

XIII. Homologies.

XIV. Alternate Generations.

XV. The Ovarian Egg.

XVI. Embryology and Classification.

Skillfully planned, and tersely written; and while embodying many general hints as to the method by which scientific truth has been reached, it sketches the history of science in past times. The knowledge which it imparts so gracefully is of the most interesting character, and is enforced by apposite and practical illustration. A more delightful scientific work we have never chanced to encounter; and we therefore cordially commend it to all classes of readers. - New York Albion.

Never before has science been so completely popularized. Philadelphia Press. 
We commend them as giving in popular form the general outline and many local details of the glacial theory which Agassiz elaborated to cosmic proportions from Charpentier's more limited groundwork, and for which he labored and battled against potent adversaries during many years, until from a hypothesis he reduced it to a demonstration. - New York World.

The simple grace of style, the pure and idiomatic English, itself a model for the student, the clearness of illustration, the certainty of the author's grasp of his subject, give them a wonderful charm, even to those who neither know nor care for their subject. Some men can make any subject interesting to any one. Among these Professor Agassiz was prominent. - Portland Press.

\section{A JOURNEY IN BRAZIL.}

By Professor and Mrs. Louis Agassiz. With eight full-page Illustrations and many smaller ones, from photographs and sketches. 8vo, $\$ 5.00$.

\section{CONTENTS}

I. Voyage from New York to Rio de Janeiro.

II. Rio de Janeiro and its Environs - Juiz de Fora.

III. Life in Rio - Fazenda Life.

IV. Voyage up the Coast to Pará.

V. From Pará to Manaos.

VI. Life at Manaos - Voyage from Manaos to Tabatinga.

VII. Life in Tefeé.

VIII. Return to Manaos - Amazonian Picnic.

IX. Manaos and its Neighborhood.

X. Excursion to Mauhes and its Neighborhood.

XI. Return to Manaos - Excursion on the Rio Negro.

XII. Down the River to Pará - Excursions on the Coast.

XIII. Physical History of the Amazons.

XIV. Ceará.

XV. Public Institutions of Rio - Organ Mountains.

XVI. General Impressions of Brazil.

Appendix.

The volume possesses a high degree of interest in the richness of its details concerning the manners and customs, social life, and natural scenery, of Brazil, its animated and often picturesque narrative, and the graceful freedom and simplicity of its style. - Nerv York Tribune.

The narrative is interwoven with some of the more general re. sults of Prof. Agassiz's scientific observations, especially his in 
quiries into the distribution of the fishes in the greatest hydro. graphic basin in the world, and the proof of the former existence of glaciers throughout its extent. The vegetation of the tropics, seen by Prof. Agassiz from a paleontological point of view, is drawn in charming pictures by Mrs. Agassiz's pen. - Fournal of Travel and Natural History (London).

A most charming and instructive volume. It will be an indispensable companion for every traveller in Brazil ; and its intrinsic merits assure for it general favor and circulation. - Pall Mall Gazette.

A more charming volume of travels we have seldom met with. - Springfield Republican.

It is impossible to give the reader an idea of the wealth in the volume. - Boston Transcript.

\section{SEASIDE STUDIES IN NATURAL HISTORY.}

\section{By Elizabeth C. Agassiz and Alexander Agassiz.} With one hundred and eighty-five Illustrations. 8 vo, $\$ 3.00$.

This beautiful volume is an admirable companion for the seaside resident or tourist, especially for all who are capable of pleasure from looking at or studying the life of the sea. Professor Alexander Agassiz gives the results of his own extended observations and profound researches, relating to the structure, habits, growth, development from the embryo, and other characteristics of New England polyps, jelly-fishes or medusæ, and star-fishes, illustrating his descriptions with numerous artistic figures; and Mrs. Agassiz adds to the volume the charm of her graceful pen. "Seaside Studies in Natural History" is a work for the learned as well as unlearned, fitted to give all delight and instruction. Professor JAMES D. DANA, in American Fournal of Science.

\section{LOUIS AGASSIZ:}

\section{HIS LIFE AND CORRESPONDENCE.}

Edited by Elizabeth C. Agassiz. With Portraits and Illustrations. 2 vols. crown 8 vo. \$4.00.

This volume gives a full account of Professor Agassiz, his work and writings, and also contains copious selections from his correspondence. It is the most extended biography of him which has ever been published. 


\section{GEOLOGICAL SKETCHES.}

By Louis Agassiz. First Series. With Illustrations. I $6 \mathrm{mo}, \$ 1.50$.

CONTENTS:

I. America the Old World.

II. The Silurian Beach.

III. The Fern Forests of the Carboniferous Period.

IV. Mountains and their Origin.

V. The Growth of Continents.

VI. The Geological Middle Age.

VII. The Tertiary Age, and its Characteristic Animals.

VIII. The Formation of Glaciers.

IX. Internal Structure and Progression of Glaciers.

X. External Appearance of Glaciers.

This work has been extensively read and admired for the sim. plicity and beauty of its style, the vividness of its descriptions of Nature, and the grandeur of its views of the world's progress. Professor Agassiz reviews the prominent events of the successive eras in a manner that cannot fail to charm and instruct the most unscientific reader. - American Fournal of Science.

The style of these essays is clear; the information such as to stimulate, as well as enlighten, the mind; and the illustrations serve as good aids to the thorough comprehension of the text. Boston Transcript.

\section{GEOLOGICAL SKETCHES.}

By Louis Agassiz. Second Series. I6mo, $\$ 1.50$.

I. Glacial Period. CONTENTS:

II. The Parallel Roads of Glen Roy, in Scotland.

III. Ice-Period in America.

IV. Glacial Phenomena in Maine.

V. Physical History of the Valley of the Amazon.

This volume, taken in connection with the first series of "Geological Sketches," presents in a permanent form, and in their proper order, all the essays Professor Agassiz wrote in his maturer years on geological and glacial phenomena.

These papers, rich with accumulated stores of scientific lore, and seeming, in their simple but animated and engaging style, to be genuine outgrowths of their author's temperament, as well as of his wisdom, need no recommendation. - Boston Advertiser. 


$$
\text { . }
$$





\section{$-$}

II.

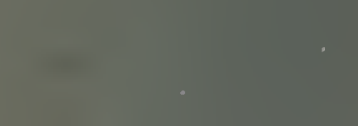

$+$

$-$

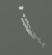

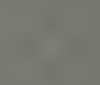
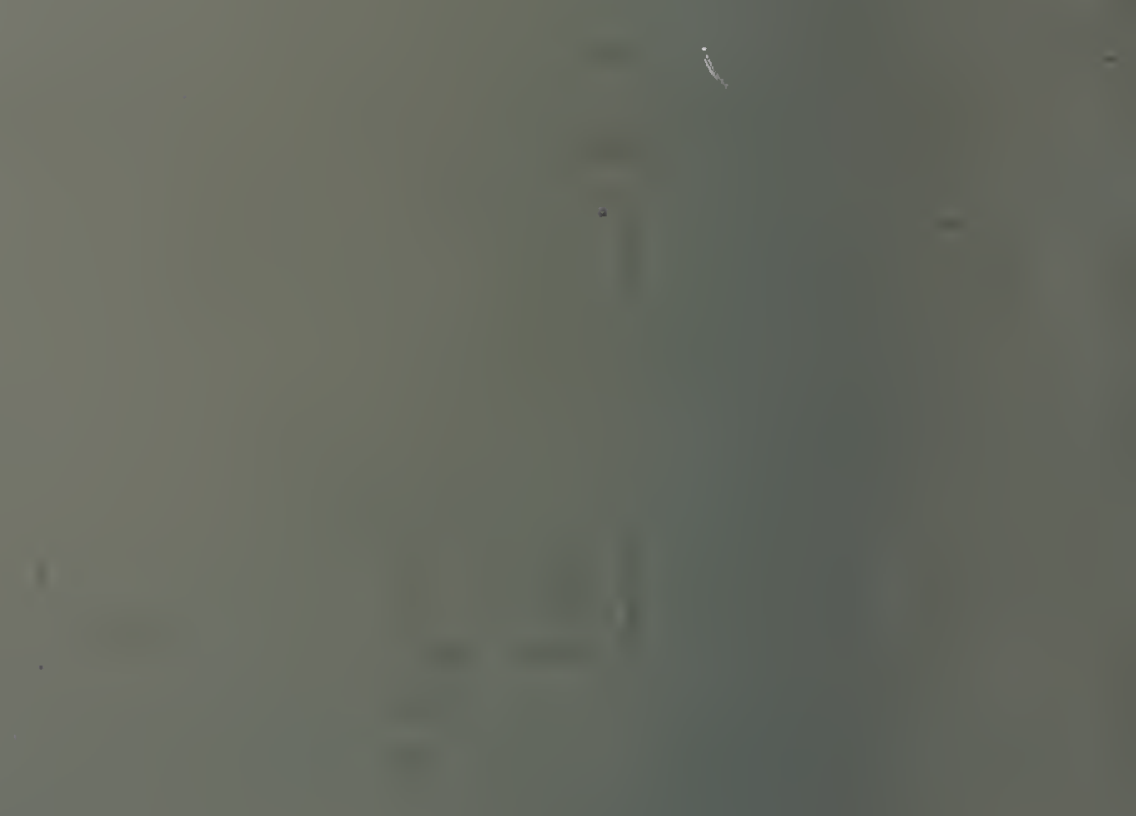


\section{NOTICE TO BORROWER}

This card is to be kept in this pocket and returned with the book.

No book will be loaned without presentation of the borrower's card.

This book must be returned on or before the last date stamped on the card.

If not requested by another borrower the loan may, on apF cation, be renewed.

This I ok nust not be marked or mutilated in any wav.

In case of loss its value must be paid to the Librarian.

Any violation of these rules may deprive the borrower of any further privileges of the Library.

Department of Education, Toronto. 
